WSRC-TR-2003-00285, REVISION 0

SRT-RPP-2003-00130, REVISION 0

\title{
RPP-WTP LAW MELTER OFFGAS FLAMMABILITY ASSESSMENT
}

\author{
SEPTEMBER 2003
}

SAVANNAH RIVER TECHNOLOGY CENTER

Westinghouse Savannah River Company Savannah River Site Aiken, SC 29808

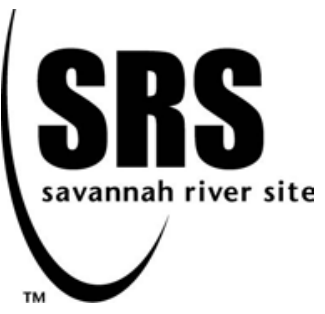


This document was prepared in conjunction with work accomplished under Contract No. DE-AC09-96SR18500 with the U. S. Department of Energy.

\section{DISCLAIMER}

This report was prepared as an account of work sponsored by an agency of the United States Government. Neither the United States Government nor any agency thereof, nor any of their employees, makes any warranty, express or implied, or assumes any legal liability or responsibility for the accuracy, completeness, or usefulness of any information, apparatus, product or process disclosed, or represents that its use would not infringe privately owned rights. Reference herein to any specific commercial product, process or service by trade name, trademark, manufacturer, or otherwise does not necessarily constitute or imply its endorsement, recommendation, or favoring by the United States Government or any agency thereof. The views and opinions of authors expressed herein do not necessarily state or reflect those of the United States Government or any agency thereof.

This report has been reproduced directly from the best available copy.

Available for sale to the public, in paper, from: U.S. Department of Commerce, National Technical Information Service, 5285 Port Royal Road, Springfield, VA 22161, phone: (800) 553-6847, fax: (703) 605-6900

email: orders@ntis.fedworld.gov

online ordering: http://www.ntis.gov/help/index.asp

Available electronically at http://www.osti.gov/bridge

Available for a processing fee to U.S. Department of Energy and its contractors, in paper, from: U.S. Department of Energy, Office of Scientific and Technical Information, P.O. Box 62, Oak Ridge, TN 37831-0062,

phone: (865)576-8401,

fax: (865)576-5728

email: $\underline{\text { reports@ adonis.osti.gov }}$ 
Key Words:

Computer Model

Melter cold cap

Plenum Combustion

\title{
Retention:
}

Permanent

Key WTP R\&T References:

Test Specification

24590-WTP-TSP-RT 02-003, Rev. 0

Task Plan: WSRC-TR-2002-00234, Rev. 0

R\&T Focus Area: Vitrification

\section{RPP-WTP LAW MELTER OFFGAS FLAMMABILITY ASSESSMENT}

\author{
A. S. Choi, SRTC \\ F. G. Smith, III, SRTC
}

SEPTEMBER 2003

Westinghouse Savannah River Company

Savannah River Site

Aiken, SC 29808

Prepared for the U.S. Department of Energy Under Contract Number DE-AC09-96SR18500

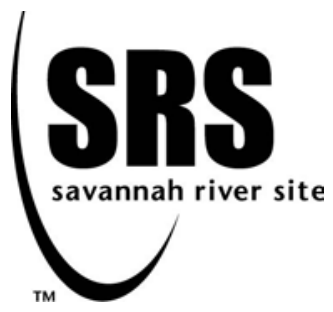




\section{TABLE OF CONTENTS}

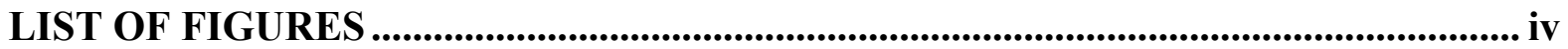

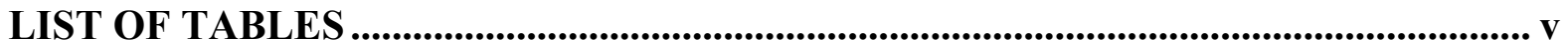

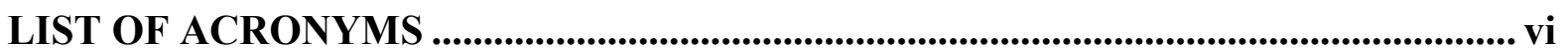

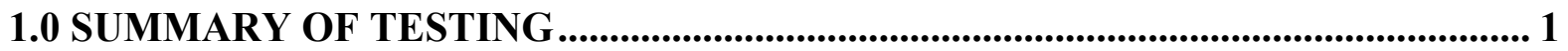

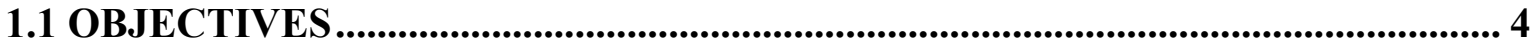

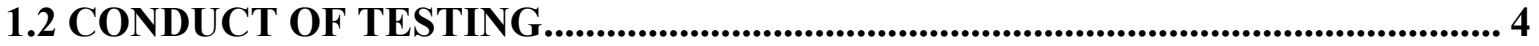

1.3 RESULTS AND PERFORMANCE AGAINST OBJECTIVES ........................... 7

1.4 QUALITY REQUIREMENTS.......................................................................... 10

1.5 ISSUES ............................................................................................................... 11

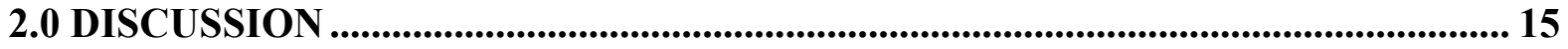

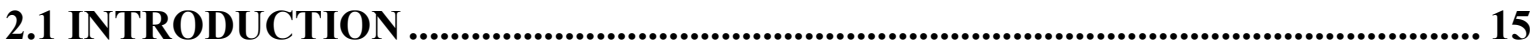

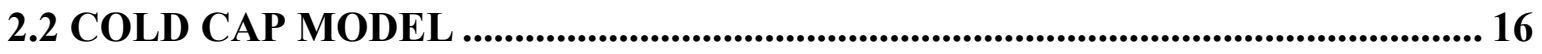

2.2.1 Cold Cap Model Development .................................................................................. 22

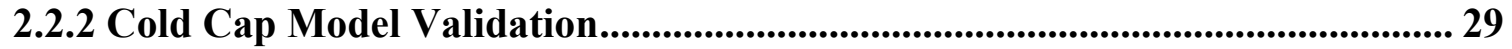

2.3 MELTER PLENUM COMBUSTION MODEL ......................................................... 40

2.3.1 Development of LAW Combustion Model............................................................. 41

2.3.1.1 DWPF Combustion Model......................................................................... 42

2.3.1.2 Bases of LAW Melter Combustion Model................................................ 45

2.3.1.3 Results of LAW Melter Combustion Model............................................... 49

2.3.2 Validation of LAW Plenum Combustion Model ................................................. 52

2.3.2.1 Input for Model Validation Run.............................................................. 53

2.3.2.2 Results of Model Validation Run .................................................................... 55

2.4 SAFETY SIMULATION .......................................................................... 59

2.4.1 Bases of Case Studies ...................................................................................60

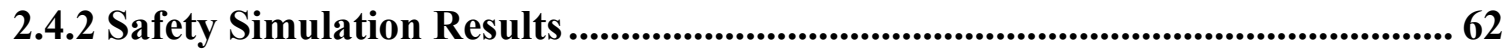

2.4.2.1 Stage 1 Case Study ...........................................................................................62 62

2.4.2.2 Stage 2 Case Study ..............................................................................66

2.4.2.3 Stage 3 Case Study ....................................................................................... 68

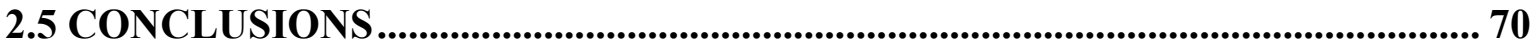

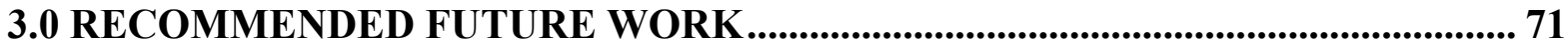

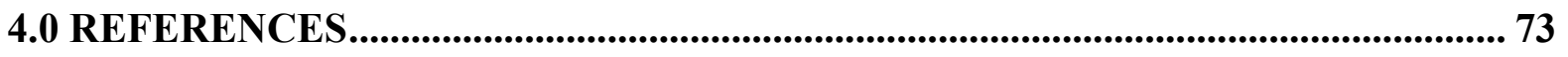

APPENDIX A. FACT/SAGE CHEMICAL SPECIES .......................................... 75

APPENDIX B. COMPOSITION OF MODEL FEED STREAMS ............................. 77

APPENDIX C. BASELINE CALCINE GAS COMPOSITIONS FOR HIGHER SUGAR RUNS.................................................................................... 79

APPENDIX D. RELATIVE FLAMMABILITIES OF HC SPECIES ......................... 83

APPENDIX E. CALCULATED COMPOSITIONS OF THE SBS VENT .................. 85 


\section{LIST OF FIGURES}

Figure 2-1. Six-stage FACT/Sage Cold Cap Model 20

Figure 2-2. Product Distribution from the Pyrolysis of One Mole of Acetic Acid as a Function of Temperature

Figure 2-3. Model prediction of carbon distribution compared to DM10 experimental data with A1 feed

Figure 2-4. Model prediction of hydrogen production compared to DM10 experimental data with A1 feed

Figure 2-5. Model prediction of ammonia production compared to DM10 experimental data with A1 feed 26

Figure 2-6. Model prediction of methane production compared to DM10 experimental data with A1 feed

Figure 2-7. Benchmarking of cold cap model feed distribution at elevated sugar levels against DM100 experimental data on glass redox with A3 feed

Figure 2-8. Cold cap model prediction of offgas generation as a function of sugar level with A3 feed

Figure 2-9. Model prediction of carbon distribution compared to DM10 experimental data with $\mathrm{C} 2$ feed

Figure 2-10. Model prediction of hydrogen production compared to DM10 experimental

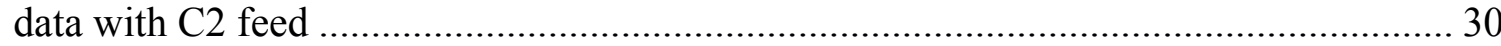

Figure 2-11. Model prediction of ammonia production compared to DM10 experimental data with $\mathrm{C} 2$ feed

Figure 2-12. Model prediction of methane production compared to DM10 experimental data with $\mathrm{C} 2$ feed

Figure 2-13. Model prediction of carbon monoxide concentration in cold cap offgas compared to DM10 experimental data with C2 feed....

Figure 2-14. Model prediction of hydrogen concentration in cold cap offgas compared to DM10 experimental data with $\mathrm{C} 2$ feed

Figure 2-15. Model prediction of ammonia concentration in cold cap offgas compared to

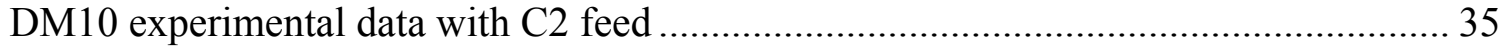

Figure 2-16. Model prediction of methane concentration in cold cap offgas compared to

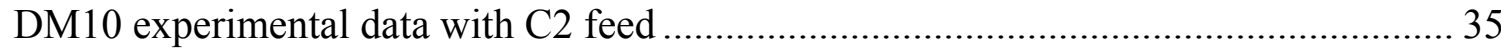

Figure 2-17. Model prediction of carbon distribution compared to DM10 experimental data with $\mathrm{A} 2$ feed.

Figure 2-18. Model prediction of hydrogen production compared to DM10 experimental data with A2 feed

Figure 2-19. Model prediction of ammonia production compared to DM10 experimental data with A2 feed

Figure 2-20. Model prediction of methane production compared to DM10 experimental data with $\mathrm{A} 2$ feed.

Figure 2-21. Model prediction of carbon distribution production compared to DM1200

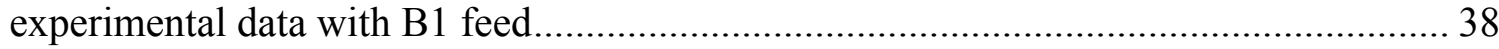

Figure 2-22. Model prediction of hydrogen production compared to DM1200 experimental

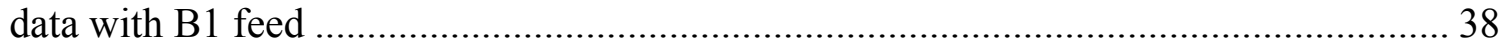


WSRC-TR-2003-00285, REVISION 0

SRT-RPP-2003-00130, REVISION 0

Figure 2-23. Model prediction of ammonia production compared to DM1200 experimental data with B1 feed

Figure 2-24. Model prediction of methane production compared to DM1200 experimental data with B1 feed

Figure 2-25. Calculated Concentrations of CO Using DWPF Combustion Model vs.

Measured Data During 774-A Melter Run....

Figure 2-26. Calculated Concentrations of $\mathrm{H}_{2}$ Using DWPF Combustion Model vs.

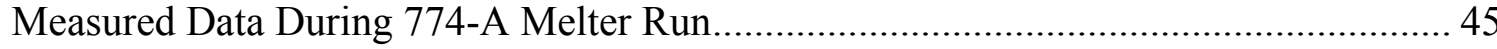

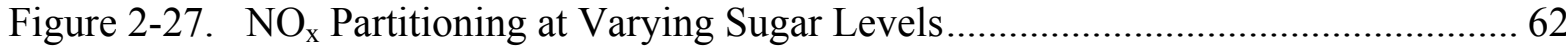

Figure 2-28. Required Combustion Air at 50\% in Excess of Stoichiometric Amount........ 64

Figure 2-29. Required Combustion Air at 20\% in Excess of Stoichiometric Amount........ 64

Figure 2-30. 7X/3X Offgas Surge with 1X Nominal Sugar @ $400{ }^{\circ} \mathrm{C}$ Plenum Temperature

\section{LIST OF TABLES}

Table 2-1. Organic Species StochiometricConversions................................................... 18

Table 2-2. Global First-Order Kinetic Parameters for DWPF Melter Plenum Combustion

Model (Derived from SGM-9 Data) ........................................................................... 44

Table 2-3. Predicted vs. Adjusted Envelope A1 Calcine Gas Compositions ...................... 48

Table 2-4. Process Data Input to LAW Model for DM1200 A1 Run................................. 49

Table 2-5. LAW Model Results vs. Measured Data During DM1200 A1 Run................... 50

Table 2-6. Global First-Order Kinetic Parameters for LAW Melter Plenum Combustion

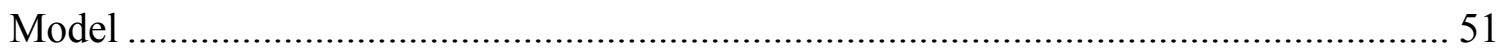

Table 2-7. Predicted vs. Adjusted Envelope B1 Calcine Gas Compositions...................... 54

Table 2-8. Process Data Input to LAW Model for DM1200 B1 Run................................ 55

Table 2-9. Estimated Process Parameters During DM1200 B1 Run .................................. 56

Table 2-10. Comparison of Offgas Compositions Predicted by LAW Melter Combustion

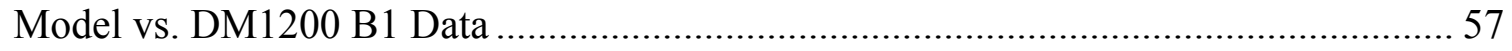

Table 2-11. Predicted Melter Exhaust Composition vs. Plenum Sampling Probe Data during

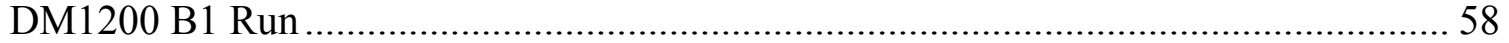

Table 2-12. Results of Stage 1 Case Study for LAW Melter Offgas Flammability

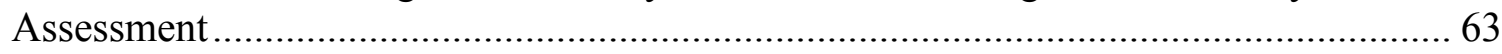

Table 2-13. Results of Stage 2 Case Study for LAW Melter Offgas Flammability

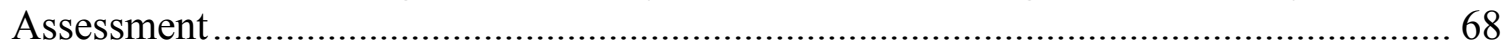

Table 2-14. Results of Stage 3 Case Study for LAW Melter Offgas Flammability

Assessment 


\section{LIST OF ACRONYMS}

$\begin{array}{ll}\text { CCTV } & \text { Closed Circuit Television } \\ \text { CLFL } & \text { Composite Lower Flammability Limit } \\ \text { DM } & \text { DuraMelter } \\ \text { DWPF } & \text { Defense Waste Processing Facility } \\ \text { FSAR } & \text { Final Safety Analysis Report } \\ \text { HC } & \text { Hydrocarbon } \\ \text { ITS } & \text { Important-to-Safety } \\ \text { LAW } & \text { Low Activity Waste } \\ \text { LFL } & \text { Lower Flammability Limit } \\ \text { NFPA } & \text { National Fire Protection Association } \\ \text { PSR } & \text { Perfectly Stirred Reactor } \\ \text { RPP } & \text { River Protection Project } \\ \text { SBS } & \text { Submerged Bed Scrubber } \\ \text { SRS } & \text { Savannah River Site } \\ \text { SRTC } & \text { Savannah River Technology Center } \\ \text { THC } & \text { Total Hydrocarbons } \\ \text { TOC } & \text { Total Organic Carbon } \\ \text { VSL } & \text { Vitreous State Laboratory } \\ \text { WESP } & \text { Wet Electrostatic Precipitator } \\ \text { WSRC } & \text { Westinghouse Savannah River Company } \\ \text { WTP } & \text { Waste Treatment Plant }\end{array}$


WSRC-TR-2003-00285, REVISION 0

SRT-RPP-2003-00130, REVISION 0

\subsection{SUMMARY OF TESTING}

The objective of this work was to develop predictive models for the Low Activity Waste (LAW) melter offgas flammability assessment and to conduct case studies in support of the on-going safety analysis efforts for the River Protection Project Waste Treatment Plant (RPPWTP). This required that Savannah River Technology Center (SRTC) personnel develop process models that are comprehensive enough to explicitly describe the effects of key melter operating variables such as total organic carbon (TOC) in the feed, melter air purge, and vapor space temperature on the offgas flammability. Once validated against the pilot melter data from Vitreous State Laboratory (VSL), these models were then used to simulate a series of safety scenarios involving inadvertent over-batching of sugar and offgas surges using the Envelope A1 simulant as the baseline feed. Since the projected list of flammable gases in the LAW melter exhaust includes $\mathrm{H}_{2}, \mathrm{CO}$, and $\mathrm{CH}_{4}$ representing the hydrocarbon species, the resulting flammability potential of each safety case considered was calculated as percent of the composite lower flammability limit (CLFL) of all three gases:

$$
\% C L F L=100\left(\frac{\left[\mathrm{H}_{2}\right]}{L F L_{\mathrm{H}_{2}}}+\frac{[\mathrm{CO}]}{L F L_{\mathrm{CO}}}+\frac{\left[\mathrm{CH}_{4}\right]}{L F L_{\mathrm{CH}_{4}}}\right)
$$

where the concentrations are given in terms of volume percent, and the lower flammability limits (LFL) of $\mathrm{H}_{2}, \mathrm{CO}$ and $\mathrm{CH}_{4}$ are 4, 12.5 and 5 volume percent, respectively.

In order to render the modeling task more manageable, the overall scope broadly defined above was broken down into two parts, each focusing on two physically distinct regions inside the melter. The first of the two models thus developed describes the heterogeneous gas-liquid-solid reactions occurring in the cold cap and melt pool, and it predicts both glass and calcine gas compositions from a given feed chemistry using thermodynamic equilibrium principle. The resulting calcine gas composition then becomes the input to the second model, which describes the homogeneous gas-phase combustion reactions in the plenum above the melt line, and it calculates time-dependent combustion efficiencies of two major flammable gases, $\mathrm{CO}$ and $\mathrm{H}_{2}$, using the global oxidation kinetics scheme.

One of the prerequisite conditions of the plenum combustion model is that the melter air purge must be provided in sufficient excess of the stoichiometric requirement to burn all flammable gases entering the plenum reactor. Otherwise, the non-ideal mixing of various gas streams entering the plenum reactor must be explicitly accounted for in order to adequately predict deteriorating combustion efficiency in the air-deficient systems. Such an effort will inevitably involve the development and validation of a comprehensive computational fluid dynamic (CFD) model, which is clearly beyond the scope of this work. Melter air purge is defined here as any mode of air injection, both incidental and controlled, into the melt pool and plenum. In this work, two different excess combustion air requirements were considered; $20 \%$ excess air as used in typical industrial applications to overcome non ideal gas mixing in the combustion chamber, and the more conservative 50\% excess air based on the fact that the melter plenum with multiple air/fuel inlets was not designed to be an efficient combustor. 


\section{WSRC-TR-2003-00285, REVISION 0 SRT-RPP-2003-00130, REVISION 0}

Among the sources of air available for combustion, air inleakage is not a controlled air purge; it constantly varies in proportion to the amplitude of melter pressure fluctuations that are induced by both short and long term disturbances such as pulse feeding, offgas surges, and deteriorating seals with the increasing age of a melter. In this work, the LAW melter air inleakage was varied from the most conservative value of zero to the projected value of $300 \mathrm{scfm}$ for normal operation in order to assess its impact on the resulting flammability potential.

The safety case studies were conducted in stages.

In Stage 1, the effects of sugar over-batching up to 4 times nominal and melter operating modes on the offgas flammability were assessed independently in order to determine the maximum sugar levels that can be tolerated under normal and upset conditions at the baseline fixed melter air purge. The two operating modes considered were normal and transient operation induced by an offgas surge. The peak intensity of the offgas surge was set at $7 \mathrm{X} / 3 \mathrm{X}$, representing 7 times the nominal condensable (steam generated from free $\mathrm{H}_{2} \mathrm{O}$ in feed) and 3 times the nominal noncondensable (calcine gas) flows, respectively.

In Stage 2, the effect of varying air purge on the offgas flammability was assessed under the conditions of simultaneous sugar over-batching and offgas surges at the melter plenum temperatures of the nominal $400{ }^{\circ} \mathrm{C}$ and the projected minimum of $300{ }^{\circ} \mathrm{C}$.

Finally, in Stage 3, the degree of sugar over-batching that would result in $25 \%$ of the CLFL at the SBS exit was determined under the conservative operating scenario of $7 \mathrm{X} / 3 \mathrm{X}$ offgas surge at the minimum air purge and minimum melter plenum temperature.

Some of the key findings from the case studies include:

- At nominal (1X) sugar, the highest flammability potential of the Submerged Bed Scrubber (SBS) vent is predicted to be $20 \%$ of the LFL during a $7 \mathrm{X} / 3 \mathrm{X}$ offgas surge at the initial melter plenum temperature of $300{ }^{\circ} \mathrm{C}$ with no melter air inleakage and no melter pressure control air.

- At 1.12X nominal sugar, the highest flammability potential of the SBS vent is predicted to be $33 \%$ of the CLFL during a $7 \mathrm{X} / 3 \mathrm{X}$ offgas surge at the initial melter plenum temperature of $300{ }^{\circ} \mathrm{C}$ with no melter air inleakage and no melter pressure control air.

- At 1.12X nominal sugar, the highest flammability potential of the SBS vent is predicted to decrease from $33 \%$ to $25 \%$ of the CLFL, if the melter air inleakage equaling $39 \%$ of the baseline $300 \mathrm{scfm}$ is allowed. 


\section{WSRC-TR-2003-00285, REVISION 0 SRT-RPP-2003-00130, REVISION 0}

- At $2 \mathrm{X}$ nominal sugar, the highest flammability potential of the SBS vent is predicted to be $127 \%$ of the CLFL during a $7 \mathrm{X} / 3 \mathrm{X}$ offgas surge at the initial melter plenum temperature of $300{ }^{\circ} \mathrm{C}$ with no melter air inleakage and no melter pressure control air, provided the baseline fixed melter air purge is increased from 101 to $139 \mathrm{scfm}$.

- At $2 X$ nominal sugar, the highest flammability potential of the SBS vent is predicted to decrease from $127 \%$ to $55 \%$ of the CLFL during a $7 \mathrm{X} / 3 \mathrm{X}$ offgas surge, when the baseline melter air inleakage and pressure control air flows are both included at the initial melter plenum temperature of $400{ }^{\circ} \mathrm{C}$.

- For normal operation with no offgas surges, the worst-case flammability potential of the SBS vent is predicted to be $49 \%$ of the CLFL at $4 \mathrm{X}$ nominal sugar, provided the minimum $20 \%$ excess combustion air requirement is met.

- For normal operation with no offgas surges, the melter plenum temperature between 300 and $400{ }^{\circ} \mathrm{C}$ has a significant impact on the offgas flammability; during offgas surges, however, it has practically no impact.

- With the baseline fixed melter air purge of $101 \mathrm{scfm}$, the maximum tolerable level of sugar in terms of satisfying the minimum $50 \%$ excess combustion air is $1.6 \mathrm{X}$ nominal or $60 \%$ over-batching under normal operation.

- With the total melter air purge of $401 \mathrm{scfm}$, including $300 \mathrm{scfm}$ air inleakage, the maximum tolerable level of sugar in terms of satisfying the minimum $50 \%$ excess combustion air is $3.9 \mathrm{X}$ nominal or $290 \%$ over-batching under normal operation.

- With the baseline fixed melter air purge of $101 \mathrm{scfm}$, the maximum tolerable level of sugar in terms of satisfying the minimum $20 \%$ excess combustion air is $1.8 \mathrm{X}$ nominal or $80 \%$ over-batching under normal operation.

- With the total melter air purge of $401 \mathrm{scfm}$, including $300 \mathrm{scfm}$ air inleakage, the maximum tolerable level of sugar in terms of satisfying the minimum $20 \%$ excess combustion air is higher than $4 \mathrm{X}$ nominal or well over $300 \%$ over-batching under normal operation.

Complete results of the safety case studies along with a detailed description of the model development and validation efforts made are given in this report. It should be noted that the conclusions drawn from this work will be valid only when the values assumed for the TOC (i.e., sugar over-batching), melter air purge, and plenum temperature are within their respective maximum or minimum limits used in each simulation run. 


\subsection{OBJECTIVES}

Specific task objectives in the task plan are [Choi, 2002]:

1. Identify key melter operating variables affecting the offgas flammability and define the model requirements.

2. Select software that will best satisfy the model requirements.

3. Develop and validate a cold cap chemistry model that can predict both glass redox and calcine gas composition from a given feed chemistry.

4. Develop and validate a combustion model that describes the chemistry and kinetics of oxidation of volatile feed components and flammable calcine gases in the melter vapor space under a given set of melter operating conditions.

5. Run models to generate system performance data for prescribed operating and/or upset scenarios of safety concern.

To ensure their applicability, the models need to be validated against the pilot melter data. Once validated, the models can be used to generate system performance data for determining whether control/mitigation strategies are required to ensure adequate safety margin for the LAW melter operation. In essence, the models provide a computational basis for assessing the impact of proposed design and/or operational changes on the offgas flammability. Similar models have performed this function for the Defense Waste Processing Facility (DWPF) at the Savannah River Site (SRS) [Choi and Iverson, 1996].

\subsection{CONDUCT OF TESTING}

1. The FACT/Sage software package was selected to provide a database of oxides, solids, and gases appropriate for modeling the melter cold cap chemistry on the strength of the applicability of its chemical species to melter chemistry based on previous experience. $\mathrm{Chem} / \mathrm{Sage}$ was selected as the software to develop a multi-stage equilibrium reactor model of the cold cap because of its compatibility with FACT/Sage. The CHEMKIN software was selected for modeling combustion reactions in the melter plenum because of its flexibility and extensive database of gas-phase reaction parameters.

2. The software was classified as level B per WSRC E7, procedure 5.05. As such, the software functionality was verified by reproducing results from example problems published in vendor manuals and the open literature [Smail, 2003a, and Smail, 2003b]. 
3. DM10 offgas data with A1 feed obtained in March 2003 [Matlack et al., 2003d] was used as the baseline data for the cold cap model development. During this experiment, the melter was intentionally overfed to achieve low plenum temperatures. Data showed that the rate of offgas generation was greatly reduced under flooded conditions most likely because of an excessive water layer either slowing down the cold cap reactions and/or suppressing the release of calcine gases. However, we assume that even under such severe conditions the relative composition of dry calcine gases will still reflect the true cold cap conditions. Therefore, the model was tuned to produce conservative target values of 0.031 and 0.027 for the molar ratios of $\mathrm{CO} / \mathrm{CO}_{2}$ and $\mathrm{H}_{2} /\left(\mathrm{CO}+\mathrm{CO}_{2}\right)$, respectively, that would bound essentially all the data for the $1 \mathrm{X}$ nominal sugar feed. This approach is justified, since loss of $\mathrm{C}$ and $\mathrm{H}$ to glass is negligible.

4. Similarly, a target of 0.072 was selected for the molar ratio of total hydrocarbon $(\mathrm{THC}) /\left(\mathrm{CO}+\mathrm{CO}_{2}\right)$. However, it was not possible to match this conservative THC target along with those for $\mathrm{H}_{2}$ and $\mathrm{CO}$ simultaneously in the cold cap model. Consequently, the THC target was allowed to float and, in general, the predicted THC values were lower than the conservative target by a factor of about 4 for the baseline 1X sugar case.

5. Once developed, the cold cap and combustion models were validated against VSL experimental data from DM10 and DM1200 tests conducted in November 2002 and March 2003. The cold cap model was also validated for higher than normal sugar addition using data from VSL testing with Envelope A3 feed at elevated sugar levels in the DM100 melter.

6. Envelope A1 simulant used in the March 2002 DM1200 run at VSL [Matlack et al., $2002 \mathrm{~b}$ ] provided the feed composition for the flammability simulation. The choice of Envelope A1 was dictated by the feed sugar content and by the accident scenario definition as inadvertent over-batching of sugar.

7. The sugar level was increased to 2, 3, and 4 times the nominal amount added to Envelope A1 simulant to form three additional feed compositions for a total of four "integer" sugar feeds. Each of the four A1 feed compositions, excluding free water, was run in the cold cap model to predict the compositions of calcine gases and glasses. The calcine gas compositions were then used as the input to the combustion model to predict the offgas composition downstream of the melter. Additional cases were also run later by considering "fractional" sugar levels between $1 \mathrm{X}$ and $2 \mathrm{X}$ nominal.

8. It was assumed that methane, the most flammable form of hydrocarbon per unit carbon basis, represents the hydrocarbons detected during the DM10 run, and its concentration was set by tripling the THC data, since the THC monitor was calibrated for propane (see Appendix D). To correct for the loss of conservatism in Item \#4, it was assumed that methane, which is nearly as flammable as hydrogen, does not combust in the melter plenum, thus rendering the resulting melter exhaust more flammable. 


\section{WSRC-TR-2003-00285, REVISION 0 SRT-RPP-2003-00130, REVISION 0}

9. The first-order global kinetic parameters for $\mathrm{CO}$ and $\mathrm{H}_{2}$ oxidation in the melter plenum, previously derived from and validated against DWPF pilot melter data, were modified and subsequently used in a single perfectly stirred reactor (PSR) model of the LAW melter plenum. The resulting global kinetic parameters modified to match the DM1200 A1 data over predicted the measured concentrations of $\mathrm{CO}$ and $\mathrm{H}_{2}$ during the DM1200 B1 run by 5 and $29 \%$, respectively.

10. The air purges to the LAW melter included two types, fixed and variable air purges, and their component flow rates supplied by the customer are as follows [Rossell, 2003]:

Fixed air purges totaling $101 \mathrm{scfm}$ :

- $5 \mathrm{scfm}$ to bubblers

- 4 scfm to air lift lances

- $30 \mathrm{scfm}$ backup offgas duct purge

- 50 scfm plenum viewing CCTV purge

- $10 \mathrm{scfm}$ film cooler cleaner purge

- 2 scfm ADS pump blow down

Variable air purge:

- 300 scfm melter air inleakage

11. Per WTP direction, the air purge to the LAW melter film cooler was set at $170 \mathrm{cfm}$ at $99{ }^{\circ} \mathrm{C}$. This air was used as the dilution source in all cases considered. Since the film cooler air is set to be interlocked off at the melter pressure of -0.5 inches $\mathrm{H}_{2} \mathrm{O}$ or above, it was implicitly assumed that the LAW melter would not pressurize above -0.5 inches $\mathrm{H}_{2} \mathrm{O}$ under the conditions of flammability assessment assumed in this work.

12. Except during Stage 2 case studies, the LAW melter pressure control air, nominally set at $300 \mathrm{scfm}$, was not included as part of the dilution air, since it constantly modulates to dampen the fluctuations in melter pressure.

13. The impact of LAW melter air inleakage on the offgas flammability was assessed by varying it from the most conservative value of zero to the projected value of $300 \mathrm{scfm}$ for normal operation. Air inleakage impacts the outcome of flammability calculations in three ways. First, as long as the melter pressure remains negative relative to that of the surrounding cell, some degree of air inleakage will occur and be used as part of the combustion air. Second, air inleakage decreases the gas residence time in the plenum, thus lowering the combustion efficiency. Third, air inleakage also dilutes the melter exhaust, resulting in a lower potential for offgas flammability downstream. The net effect of these opposing trends was accounted for in the model.

14. The $7 \mathrm{X} / 3 \mathrm{X}$ offgas surge was assumed to proceed as follows: At $\mathrm{t}=0$, the flow rates of condensable (C) and non-condensable (NC) gases ramp up to 7 times and 3 times their respective nominal values, respectively, during the first 22 seconds. Then, at the 22 -second mark, they immediately ramp down back to their respective $1 \mathrm{X}$ nominal values during the next 89 seconds. 


\section{WSRC-TR-2003-00285, REVISION 0 SRT-RPP-2003-00130, REVISION 0}

15. The nominal temperature of the LAW melter plenum, as measured in the thermowell, is $400{ }^{\circ} \mathrm{C}$. In this work, the lower bound for this temperature was set at $300{ }^{\circ} \mathrm{C}$. Based on the results of DM1200 data analysis, the true gas temperature exiting the melter was assumed to be $40{ }^{\circ} \mathrm{C}$ lower at the indicated reading of $400{ }^{\circ} \mathrm{C}$ with this difference between the indicated and true gas temperatures decreasing to zero at the indicated reading of $200{ }^{\circ} \mathrm{C}$.

16. Before the transient simulation run, a steady state combustion model was run first for each feed case to estimate the radiant heat input into the plenum and further to provide the initial guesses for the compositions of the 11 gas species considered in the model. The steady state radiant heat input was then assumed to remain constant during the 111-second offgas surge simulation.

17. The point of offgas flammability control was set at the exit port of the SBS, and the exiting vapor was assumed to be saturated.

18. No gas holdup was assumed to occur in the SBS.

\subsection{RESULTS AND PERFORMANCE AGAINST OBJECTIVES}

Both the LAW melter cold cap and the plenum combustion models have been developed and validated using the data taken during recent pilot melter runs at VSL. The validation of the plenum combustion model was rather limited in scope, since it was validated against only two sets of data taken during the same DM 1200 B1 run [Matlack, 2003a]. Nevertheless, the overall agreement between model predictions and measured data was shown in Table 2-10 to be excellent at all three sampling locations. The acceptance criterion set for the combustion model validation was to match

(1) available offgas data for $\mathrm{H}_{2} \mathrm{O}, \mathrm{CO}, \mathrm{CO}_{2}, \mathrm{H}_{2}, \mathrm{NO}_{\mathrm{x}}$, and $\mathrm{NH}_{3}$ at the exit ports of melter, SBS and WESP

(2) $\mathrm{pH}$ of the SBS and WESP condensates

(3) temperature and flow profiles throughout the system

During the course of model validation, both melter air inleakage and true plenum gas temperature, which are perhaps two most influential variables affecting offgas flammability after the fuel concentrations, were also estimated by performing as detailed mass and energy balances as the data would allow. A reaction scheme that describes the offgas and condensate chemistry involving $\mathrm{NO}_{\mathrm{x}}$ was also developed to support the validation process.

The validated model was next used to simulate all the safety cases requested by the customer, and the results are discussed in Section 2.4.2. To overcome imperfect mixing that exists in large vessels, the model requires that an adequate supply of combustion air be provided in excess of what is required to stoichiometrically burn $100 \%$ of flammable gases entering the melter plenum. Since the amount of excess combustion air required is a function of fuel concentrations, which in turn depend on the TOC content of the feed, it is obvious that the maximum tolerable sugar level in the event of over-batching would be determined first by whether there is an adequate supply of excess combustion air to burn all that excess sugar. 


\section{WSRC-TR-2003-00285, REVISION 0 SRT-RPP-2003-00130, REVISION 0}

In this work, when the total melter air purge fell below $120 \%$ of the stoichiometric amount, the combustion model was not run, since the global kinetic parameters used in the model were derived from the data taken exclusively under fuel-lean conditions. Efforts to extend the applicable range of the model into fuel-rich regions were initiated but later discontinued, since no LAW melter offgas data have been taken to date under such fuel-rich conditions to validate the model results.

Since air inleakage makes up for $75 \%$ of the total LAW melter air purge specified by the customer, whether to include it as part of the combustion air or to leave it out completely has a profound impact on the total excess combustion or dilution air available. One of the goals of safety simulation runs was to quantify these impacts that the melter air inleakage has on the process of determining compliance to a given excess air requirement and the resulting maximum allowable sugar level and offgas flammability.

The safety case studies were conducted in three stages. A total of 16 cases were run during Stage 1 at the indicated melter plenum temperature of $400{ }^{\circ} \mathrm{C}$ and by not counting the melter pressure control air as a dilution source. Some of the highlights from the Stage 1 case study include:

- Without taking any credit for the melter air inleakage as part of the combustion and dilution air, the maximum sugar level that can be tolerated under the minimum 50\% excess combustion air requirement would be 1.6 times the nominal. With the resulting feed containing $60 \%$ over-batched sugar, the steady state concentration of flammable gases at the SBS exit was predicted to be $14 \%$ of the CLFL.

- If the minimum excess combustion air requirement is lowered from $50 \%$ to $20 \%$, the maximum tolerable sugar level in the absence of melter air inleakage would increase to 1.8 times the nominal. With the resulting feed containing $80 \%$ overbatched sugar, the steady state concentration of flammable gases at the SBS exit was predicted to increase to $19 \%$ of the CLFL.

- The maximum allowable sugar level for normal operation is determined by both the fixed melter air purge and the minimum excess combustion air requirement and not by the flammability potential of the SBS vent. The combustion model could not be run when the excess combustion air flow fell below the minimum $20 \%$. However, it is known that with no adequate supply of excess air the combustion efficiency will deteriorate rapidly.

- If the baseline melter air inleakage of $300 \mathrm{scfm}$ is included as part of the combustion and dilution air, the maximum sugar level that can be tolerated under the minimum $50 \%$ excess combustion air requirement would be 3.9 times the nominal. With the resulting feed containing $290 \%$ over-batched sugar, the steady state concentration of flammability gases at the SBS exit was predicted to be $38 \%$ of the CLFL. 


\section{WSRC-TR-2003-00285, REVISION 0 SRT-RPP-2003-00130, REVISION 0}

- If an adequate supply of excess combustion air is to be ensured in the case of sugar over-batching by up to $300 \%$ (or at 4 times the nominal sugar level) without taking credit for the melter air inleakage as part of the combustion air, the current baseline fixed melter air purge of $101 \mathrm{scfm}$ would have to be increased to 420 scfm in order to meet the minimum $50 \%$ excess combustion air requirement. With this increased melter air purge and 4 times the nominal sugar, the steady state concentration of flammable gases at the SBS exit was predicted to increase to $44 \%$ of the CLFL.

- If the minimum combustion air requirement is lowered from $50 \%$ to $20 \%$ in excess of the stoichiometric amount, and it is also desired to maintain a conservative operating basis by not taking credit for the melter air inleakage as part of the combustion air, the current baseline fixed melter air purge of $101 \mathrm{scfm}$ would have to be increased to $336 \mathrm{scfm}$ in order to ensure an adequate supply of combustion air at the sugar level as high as 4 times the nominal. With this increased melter air purge and 4 times the nominal sugar, the steady state concentration of flammable gases at the SBS exit was predicted to be $49 \%$ of the CLFL.

- For the transient operating mode induced by the $7 \mathrm{X} / 3 \mathrm{X}$ offgas surges at the nominal sugar level, the peak concentration of flammable gases at the SBS exit was predicted to be $20 \%$ of the CLFL without taking credit for the melter air inleakage as part of the combustion and dilution air. When the melter air inleakage was included as part of the combustion and dilution air, the peak concentration of flammable gases at the SBS exit was predicted to decrease from 20 to $11 \%$ of the CLFL.

A total of 19 additional cases were run during Stage 2 case study by setting the sugar level either at $1 \mathrm{X}$ or $2 \mathrm{X}$ nominal and the melter plenum temperature either at 300 or $400{ }^{\circ} \mathrm{C}$, while varying the air purges as follows:

1. Air inleakage OFF; Control air OFF

2. Air inleakage $\mathbf{O N}$; Control air $\mathbf{O F F}$

3. Air inleakage $\mathbf{O N}$; Control air $\mathbf{O N}$

Since the baseline melter air inleakage and melter pressure control air flows are both set at $300 \mathrm{scfm}$, the $4^{\text {th }}$ air purge combination of air inleakage OFF and control air ON would yield practically the same results as the $2^{\text {nd }}$ air purge combination. Some of the highlights from the Stage 2 case study include:

- In the event of $7 \mathrm{X} / 3 \mathrm{X}$ offgas surges, the peak concentration of flammable gases at the SBS exit was predicted to be $55 \%$ of the CLFL for the $2 \mathrm{X}$ nominal sugar case under the least conservative operating scenario of including both melter air inleakage and pressure control air, i.e., the $3^{\text {rd }}$ air purge combination at the higher plenum temperature of $400{ }^{\circ} \mathrm{C}$. 
- In all $7 \mathrm{X} / 3 \mathrm{X}$ offgas surge cases considered, the melter plenum temperatures between 300 and $400{ }^{\circ} \mathrm{C}$ showed little or no impact on the offgas flammability.

- During normal operation with no offgas surges, however, the plenum temperature showed a strong impact on the offgas flammability. For example, in the case of $2 \mathrm{X}$ nominal sugar with the most conservative air purge scenario of excluding both melter air inleakage and pressure control air, the flammability potential of the SBS exhaust was predicted to be $47 \%$ of the CLFL at the melter plenum temperature of $300{ }^{\circ} \mathrm{C}$, which was more than twice that predicted at $400{ }^{\circ} \mathrm{C}$.

- The potential for offgas flammability was found to be remote in all 1X nominal sugar cases considered, regardless of operating mode and plenum temperature and air purge variations.

The Stage 3 case study was made iteratively under the conservative operating scenario of $7 \mathrm{X} / 3 \mathrm{X}$ offgas surges at the minimum plenum temperature of $300{ }^{\circ} \mathrm{C}$ with no melter pressure control air. One exception was that $39 \%$ of the baseline melter air inleakage rate of $300 \mathrm{scfm}$ was credited for as part of the combustion and dilution air based on the results of a recent offgas dynamics simulation study [Smith, 2002]. Some of the highlights from the Stage 3 case study include:

- It would take $12 \%$ over-batching of sugar or $1.12 \mathrm{X}$ nominal sugar for the flammable gas concentration in the SBS vent to reach $25 \%$ of the CLFL at the peak of the $7 \mathrm{X} / 3 \mathrm{X}$ offgas surge.

- If $100 \%$ of the baseline melter air inleakage rate of $300 \mathrm{scfm}$ were to be credited for as part of the combustion and dilution air, the flammability potential of the SBS vent would decrease to $19 \%$ of the CLFL at the peak of the $7 \mathrm{X} / 3 \mathrm{X}$ offgas surges.

- If no melter air inleakage were to be credited for as part of the combustion and dilution air, the flammability potential of the SBS vent would increase to $33 \%$ of the CLFL at the peak of the $7 \mathrm{X} / 3 \mathrm{X}$ offgas surges.

\subsection{QUALITY REQUIREMENTS}

This work was conducted in accordance with the RPP-WTP QA requirements specified for work conducted by SRTC as identified in DOE IWO MOSRLE60. SRTC has provided matrices to WTP demonstrating compliance of the SRTC QA program with the requirements specified by WTP. Specific information regarding the compliance of the SRTC QA program with RW-0333P, Revision 10, NQA-1 1989, Part 1, Basic and Supplementary Requirements and NQA-2a 1990, Subpart 2.7 is contained in these matrices. This work was performed under the guidance of "Task Technical and Quality Assurance Plan for LAW Melter Cold Cap and Offgas Flammability Modeling," WSRC-TR-2002-00234, Rev. 0, [Choi, 2002]. The task plan specifies that all work described in this report does not invoke the additional RW-0333P QA requirements. This work further conforms to the Important-To-Safety (ITS) requirements in 10CFR 830, Part A. 
The quality assurance and verification testing of the software used in this work is documented in two packages [Smail, 2003a and Smail, 2003b]:

(1) "WTP Melter Cold Cap Modeling Software Test Documentation", Software Test Plan G-STP-A-00004, Rev. 0, January 2003.

(2) "WTP Melter Offgas Flammability Modeling Software Test Documentation", Software Test Plan G-STP-A-00004, Rev. 0, June 2003.

The first package documents verification testing of the FACT/Sage and Chem/Sage software, while the second documents verification testing of the CHEMKIN software. Software QA was performed to a level B classification per WSRC QA procedures to satisfy requirements for a calculation that is ITS.

\subsection{ISSUES}

As shown by the results of the safety case studies, the flammability potential of the LAW melter offgas will be determined largely by:

(1) total organic carbon (TOC) content of the feed

(2) melter plenum temperature

(3) air flows for combustion and dilution

(4) operational anomalies such as offgas surges

In essence, the first three of these four variables are controlled either by the choice of flowsheet or by the operator action, and their impact on the offgas flammability is strongly interdependent. For example, when the TOC level is increased at fixed air flows, the plenum temperature would then have to be increased by reducing the feed rate and, therefore, the cold cap coverage in order to maintain a comparable concentration of flammable gases in the melter exhaust. Likewise, when the air purge to the melter is reduced at a fixed TOC level, the resulting increase in plenum temperature may have to be further augmented by reducing the feed rate accordingly to fully offset the impact of reduced dilution.

It is also noted that the ranges of variability in melter plenum temperature and air purges will be limited by the system design and/or operating constraints. The goal of this work was not to define those limiting values. Instead, the goal was to assess the relative impacts of sugar over-batching, melter plenum temperature and air purges on the offgas flammability during normal and abnormal operations.

The baseline abnormal operation selected for this work was the $7 \mathrm{X} / 3 \mathrm{X}$ offgas surge, which was shown to lead to more conservative flammability predictions than normal operation due to the compounding effects of increased fuel concentration (resulting from $3 \mathrm{X}$ nominal noncondensable surge) and lower plenum temperature (resulting from $7 \mathrm{X}$ nominal condensable surge). The relative impacts of the key melter operating variables listed above on the off-gas flammability are discussed next based on the results of the case studies pertaining to both normal and abnormal operations: 
- $\quad$ TOC - Current emphasis is on inadvertent over-batching of sugar. Since the nitrate level was held constant at its baseline value in this work, the rate of increase in the fuel concentration entering the melter plenum as a result of sugar over-batching was much higher than the rate of increase in sugar level itself. For example, when the sugar level was doubled from $1 \mathrm{X}$ to $2 \mathrm{X}$ nominal, the concentration of $\mathrm{H} 2$ in the calcine gas was increased by a factor of more than 10 (see Table 2-3 and Table C-1). The resulting flammability potential of the SBS vent during the $7 \mathrm{X} / 3 \mathrm{X}$ offgas surge was increased by a factor of at least 6.5 for all melter plenum temperatures and air purge modes considered (see Table 2-13).

For normal operation, the maximum allowable sugar level in the feed was shown to be determined by whether a given melter air purge is adequate to satisfy the minimum excess combustion air requirement and not by the offgas flammability potential. For example, the maximum allowable sugar level to satisfy the minimum $20 \%$ excess combustion air requirement without taking credit for the melter air inleakage was calculated to be $1.8 \mathrm{X}$ nominal, while the flammability potential of the SBS vent with the resulting feed containing $80 \%$ over-batched sugar was only $19 \%$ of the CLFL for normal operation (see Table 2-12).

Under the offgas surge conditions, however, the maximum allowable sugar level was shown to be determined largely by the offgas flammability potential. For example, even with $39 \%$ of the baseline melter air inleakage rate of $300 \mathrm{scfm}$ being credited for as part of the combustion and dilution air, it would take only $1.12 \mathrm{X}$ nominal sugar for the SBS vent to reach $25 \%$ of the CLFL at the peak of the $7 \mathrm{X} / 3 \mathrm{X}$ offgas surges.

- Melter plenum temperature - The baseline value of $400{ }^{\circ} \mathrm{C}$ assumed in this work was already low enough that practically there was no difference between predicted offgas flammability potentials at 300 and $400{ }^{\circ} \mathrm{C}$ during the offgas surge.

- Melter air purge - The baseline air inleakage rate of $300 \mathrm{scfm}$ makes up for $75 \%$ of the total LAW melter air purge. Therefore, whether to include it as part of the combustion and dilution air or to leave it out completely has a profound impact on the maximum allowable sugar level. When $100 \%$ of the baseline air inleakage rate was included in the calculation, the resulting flammability potential of the SBS vent was shown to decrease by $40-50 \%$ regardless of the operating mode compared to those cases where no air inleakage was allowed. However, it should be noted that this baseline air inleakage rate is only a projected value, which means that its true value that can only be estimated when the LAW melter is operational can be different from this baseline value. Furthermore, the true air inleakage value can still vary with the melter age and the scope and frequency of necessary maintenance works performed on the melter components. 
The remaining $25 \%$ of the total LAW melter air purge is controlled and therefore was included in the flammability calculations. This means that the controlled or fixed melter air purge should be maintained at or above $101 \mathrm{scfm}$ in order for the conclusions of this work to remain valid. Since this fixed air purge is made up of six different sources, an effective means of controlling these fragmented air flows would be to focus on controlling the two major flows that make up for $80 \%$ of the total fixed air purge; backup offgas duct purge and plenum viewing CCTV purge.

- Film cooler air purge - The air purge to the film cooler is controlled and therefore $100 \%$ of its $170 \mathrm{cfm}$ at $99{ }^{\circ} \mathrm{C}$ was used as the dilution source in all cases considered. Since the film cooler air is set to be interlocked off at the melter pressure of -0.5 inches $\mathrm{H}_{2} \mathrm{O}$ or above, it was implicitly assumed that the LAW melter would not pressurize above -0.5 inches $\mathrm{H}_{2} \mathrm{O}$ during the $7 \mathrm{X} / 3 \mathrm{X}$ offgas surge used in this work.

- Pressure control air - The LAW melter pressure control air flow is nominally set at $300 \mathrm{scfm}$. However, it was not included as part of the dilution air except during Stage 2 case studies, since it constantly modulates to dampen the fluctuations in melter pressure. When $100 \%$ of the baseline control air flow was included in the calculation in addition to the $300 \mathrm{scfm}$ melter air inleakage, the resulting flammability potential of the SBS vent was shown to decrease by an additional $17 \%$ regardless of the operating mode compared to those cases where no pressure control air was allowed.

- Offgas surge - To a greater or lesser extent, offgas surges are present in all slurry-fed melters but their occurrence is not predictable. For non-agitated melters such as the DWPF melter, both intensity and frequency of offgas surges are known to increase with increasing melter size. It is, however, not certain if the same trend has been observed in agitated melters such as DM100 and DM1200 melters. As for the relative impact of offgas surges, the flammability potential of the SBS vent is shown in Table 2-13 to increase by a factor of 2.6-6.5 when the operating mode was changed from normal to $7 \mathrm{X} / 3 \mathrm{X}$ offgas surge under all melter plenum temperatures and air purge modes assumed. This result shows that the $7 \mathrm{X} / 3 \mathrm{X}$ offgas surge has a somewhat lower impact on the offgas flammability than the TOC. 
WSRC-TR-2003-00285, REVISION 0

SRT-RPP-2003-00130, REVISION 0

This page intentionally left blank. 


\subsection{DISCUSSION}

The primary focus of this work was to develop and validate computer models capable of conducting an offgas flammability assessment for the WTP LAW melter and to run case studies in support of on-going safety analysis efforts. This required that the models explicitly describe the effects of key operating variables such as TOC, air purges, and melter vapor space temperature on offgas flammability. The approach taken to achieve this modeling objective was to separate the condensed phase reactions in the cold cap from the gas phase reactions in the vapor space. The calcine gas compositions calculated by the cold cap model become the input fuel composition for the vapor space combustion model. Specifically, the models must be capable of predicting glass and calcine gas compositions from a given melter feed chemistry and simulating combustion of flammable calcine gases in the melter vapor space. The models were developed using commercial software, verified by reproducing published calculations and validated against experimental data taken during pilot melter runs at the Vitreous State Laboratories (VSL). The VSL experiments were conducted at three different scales (DM10, DM100 and DM1200) using feed simulating several LAW compositions (A1, A2, A3, B1, C1 and C2).

\subsection{INTRODUCTION}

Melter chemistry modeling is very broad in scope; for the purpose of this task, it is defined as the modeling of all the chemical phenomena occurring inside the melter, including decomposition, calcination, and redox reactions in the cold cap and degassing and homogenization in the melt pool primarily via redox reactions. The gaseous products from the cold cap further react with air in the vapor space of the melter plenum. Because the composition of flammable gases entering the vapor space is determined in large part by the gas-solid-liquid reactions that occur in the cold cap and melt phases, the accurate modeling of vapor space combustion reactions relies on an accurate model of those heterogeneous reactions.

Detailed first-principles modeling of the cold cap and vapor space chemistry in a slurry-fed melter is extremely difficult even with the use of state-of-the-art computing technology. Solely from the combustion standpoint, a variety of nonvolatile organic species exist in the feed that form many different byproducts, both flammable and non-flammable, while being decomposed in the cold cap. Presently, the fate of all those organic species in both the cold cap and vapor space is not completely known, and the kinetic data for most of the reactions involved are not available.

Perhaps, the biggest obstacle to successful modeling of melter chemistry is the enormous complexity of the LAW vitrification chemistry. A very large number of waste components and glass-forming chemicals undergo simultaneous physical and chemical changes in the cold cap that has a steep temperature gradient of over $600{ }^{\circ} \mathrm{C}$ over its several-inch thickness and a spatial domain that is highly dynamic and difficult even to define. Numerous intermediate phases, both liquid and solid, are formed before the final fusion into the glass matrix takes place, and little or no attempt has been made to date to measure any physical and/or transport properties of calcine gases in these phases. 
As a result, sufficient data do not exist yet for mechanistic modeling of the cold cap. Regarding combustion modeling, the heat transfer and fluid mixing in the vapor space is sufficiently complicated that a full solution to the transport equations of reacting flows based on first principles is, if not impossible, too difficult to be practical.

Nonetheless, by using simplifying assumptions supported by experimental data, successful melter chemistry and dynamic offgas models have been developed and used to establish the DWPF safety bases and further to control key melter operating variables [Choi, 2000]. For example, as was done in the DWPF models, the gradual nature of the melting process can be approximated as a multi-stage countercurrent equilibrium process, thus ignoring the effects of chemical kinetics and transport resistances within the cold cap and melt. One of the key technical safety requirements (TSRs) used to control offgas flammability in DWPF is the total organic carbon (TOC) content of the feed. The TOC content of the WTP LAW melter feeds, especially Envelope $\mathrm{C}$, is considerably higher than that of the DWPF feeds and is further augmented by the addition of sugar to control glass redox. These carbon species are decomposed in the cold cap to produce such flammable gases as $\mathrm{CO}, \mathrm{H}_{2}$ and light hydrocarbons, and the degree to which these flammable gases are reacted in the melter plenum directly impacts the offgas flammability potential downstream of the SBS.

Therefore, offgas flammability is determined not only by the TOC content of feed, but by other operating variables affecting the combustion efficiency in the melter such as vapor space temperature and the rate of air purge. Besides those melter operating variables that can be monitored and controlled, offgas flammability is also impacted by the unpredictable, therefore, uncontrollable process/system upsets such as offgas surges, unintentional melter overfeeding, equipment malfunction and even an earthquake. The work described in this report addresses these issues by developing models of the cold cap and plenum combustion validated using experimental data and by introducing appropriate conservatism into the flammability assessment.

\subsection{COLD CAP MODEL}

The cold cap model uses FACT/Sage to provide a database of thermodynamic properties and Chem/Sage to create a multi-stage reactor model to represent the melter cold cap. Each stage in the Chem/Sage reactor model performs a chemical equilibrium calculation at constant temperature using the FACT/Sage thermodynamic data. The stages are arranged in vertical layers with countercurrent flow of solid products from the equilibrium calculations downward through the stages and upward flow of gas products. Adjustable parameters in the model are: selection of chemical species, the number of stages in the reactor model, stage temperatures, the distribution of feed between stages, and the distribution of gas and solid products flowing from each stage to succeeding stages. Note that since equilibrium calculations are performed, no specific reaction mechanisms are invoked in the model. 
The FACT/Sage software was chosen for this application because it specializes in inorganic systems and provides several optimized data sets appropriate for modeling glass melts [Pelton and $\mathrm{Wu}, 1999$, Pelton et al., 1993]. Three of these data sets (Slag A, Slag C, and Spinel) were used in the cold cap model. Slag A contains magnesium, iron, calcium, sodium and potassium as oxides, sulfates, chlorides and fluorides along with alumina, silica and titanium oxide. Slag $\mathrm{C}$ includes sodium, calcium and magnesium as sulfates and hydroxides, boron oxide and some of the same species present in Slag A. The Spinel phase contains oxides of iron, zinc and aluminum.

In addition to these solid phases, a condensed phase containing another 42 solid species was created. The solid species in the condensed phase were selected based on results from a series of preliminary FACT/Sage calculations using the entire database. The 42 species were those having an activity $>0.3$ in the temperature range of $700 \mathrm{C}$ to $1000 \mathrm{C}$. In the context of the solid solutions considered here, an activity $\geq 1.0$ indicates that the species will form and an activity $<1.0$ that the species will not form. Since all possible operating conditions could not be covered in the preliminary calculations, species with an activity $>0.3$ were included as potential products in the model. A complete list of the species in each FACT/Sage data set is provided in Appendix A. Slag A and Slag C entries in Appendix A including the notation ":2.000" are represented as the single cation form within FACT/Sage. For example, $(\mathrm{Na} 2 \mathrm{O}): 2.000$ is treated as $\mathrm{NaO}_{1 / 2}$.

While the FACT/Sage database contains a very complete set of oxides and solid species appropriate for modeling the melter cold cap, it has only a limited set of organic species. Therefore, it was necessary to convert the true organic species in the LAW feed into a set of equivalent species that were present in the FACT/Sage database. Since each stage in the reactor model performs a chemical equilibrium calculation at constant temperature calculating the product composition that minimizes total free energy, the exact form of the starting materials is not important. To accomplish this conversion, a liquid phase containing water, formic acid, acetic acid, methanol and acetonitrile was created. These four organic species along with small amounts of free carbon and carbon dioxide were used to represent organic compounds in the LAW feed. The stochiometric relations used to convert from the true LAW feed species into species compatible with FACT/Sage database are shown in Table 2-1.

The organic compounds could also have been decomposed into a set of equivalent gaseous species. However, the gas bypass factors, which distribute the gaseous products from each equilibrium stage to the upper stages in the Chem/Sage model, are applied to the feed streams as well. Therefore, since gas bypassing was used in the model, some of the gas feed would have been diverted directly to the output. The approach of feeding liquids into the cold cap model allowed the gas composition to be determined by the chemical equilibrium calculations rather than by simply splitting off some of the feed components. 
Table 2-1. Organic Species StochiometricConversions

\begin{tabular}{|c|c|}
\hline Sugar & $\mathrm{C}_{12} \mathrm{H}_{22} \mathrm{O}_{11}(\mathrm{~s}) \rightarrow 5.5 \mathrm{CH}_{3} \mathrm{COOH}+\mathrm{C}(\mathrm{s})$ \\
\hline Sodium Oxalate & $\begin{aligned} \mathrm{Na}_{2} \mathrm{C}_{2} \mathrm{O}_{4}+2 \mathrm{H}_{2} \mathrm{O} & \rightarrow \mathrm{H}_{2} \mathrm{C}_{2} \mathrm{O}_{4}+2 \mathrm{NaOH} \\
\mathrm{H}_{2} \mathrm{C}_{2} \mathrm{O}_{4} & \rightarrow \mathrm{HCOOH}+\mathrm{CO}_{2}(\mathrm{~g})\end{aligned}$ \\
\hline Sodium Formate & $\mathrm{HCOONa}+\mathrm{H}_{2} \mathrm{O} \rightarrow \mathrm{HCOOH}+\mathrm{NaOH}$ \\
\hline Sodium Acetate & $\mathrm{CH}_{3} \mathrm{COONa}+\mathrm{H}_{2} \mathrm{O} \rightarrow \mathrm{CH}_{3} \mathrm{COOH}+\mathrm{NaOH}$ \\
\hline Citric Acid & $\mathrm{C}_{6} \mathrm{H}_{8} \mathrm{O}_{7} \rightarrow 3 \mathrm{HCOOH}+0.5 \mathrm{CH}_{3} \mathrm{COOH}+2 \mathrm{C}(\mathrm{s})$ \\
\hline Glycolic Acid & $\mathrm{C}_{2} \mathrm{H}_{4} \mathrm{O}_{3} \rightarrow \mathrm{HCOOH}+0.5 \mathrm{CH}_{3} \mathrm{COOH}$ \\
\hline Iminodiacetic Acid & $\mathrm{C}_{4} \mathrm{H}_{7} \mathrm{NO}_{4} \rightarrow 2 \mathrm{HCOOH}+\mathrm{CH}_{3} \mathrm{CN}$ \\
\hline EDTA & $\begin{aligned} \mathrm{C}_{10} \mathrm{H}_{18} \mathrm{O}_{7} \mathrm{~N}_{2} \rightarrow & 2.5 \mathrm{HCOOH}+0.25 \mathrm{CH}_{3} \mathrm{COOH}+1.5 \mathrm{C}(\mathrm{s}) \\
& +2 \mathrm{CH}_{3} \mathrm{CN}+1.5 \mathrm{CH}_{3} \mathrm{OH}\end{aligned}$ \\
\hline HEDTA & $\begin{aligned} \mathrm{C}_{10} \mathrm{H}_{16} \mathrm{O}_{8} \mathrm{~N}_{2} \rightarrow & 3 \mathrm{HCOOH}+\mathrm{CH}_{3} \mathrm{COOH}+\mathrm{C}(\mathrm{s}) \\
& +2 \mathrm{CH}_{3} \mathrm{CN}\end{aligned}$ \\
\hline
\end{tabular}

To complete the cold cap model, the 20 ideal gases listed in Appendix A were used to form the gas phase. Since it is the most stable gaseous hydrocarbon, methane is used to represent hydrocarbons in the gas phase. It should be noted that nitrogen gas $\left(\mathrm{N}_{2}\right)$ could not be included as a possible gas species. Preliminary calculations showed that when $\mathrm{N}_{2}$ was included as a possible product chemical equilibrium predicts that essentially all of the nitrogen from nitrates and nitrites in the feed is converted to $\mathrm{N}_{2}$. This is inconsistent with the experimental data, which shows significant quantities of nitrogen oxides and ammonia in the offgas. In fact, nitrogen oxides typically account for about $40 \%$ of the nitrates in the feed [Matlack et al., 2002a] with the other $60 \%$ evolving as ammonia and $\mathrm{N}_{2}$. However, $\mathrm{N}_{2}$ is very stable and the equilibrium calculations in the cold cap model produced essentially $100 \%$ $\mathrm{N}_{2}$. Suppressing the formation of $\mathrm{N}_{2}$ created a more realistic offgas composition. Since ammonia contains a significant amount of hydrogen, the model was tuned to provide an acceptable estimate of ammonia in the offgas with the aim of improving the hydrogen prediction. However, omitting $\mathrm{N}_{2}$ as a gas product, the cold cap model over-predicts the total amount of nitrogen oxides in the offgas. This deficiency in the cold cap modeling was corrected for in the combustion model where, as described in Section 2.3, the distribution of nitrogen compounds in the cold cap gases was adjusted to better match the experimental data. 
Since the reactor model is based on idealized equilibrium calculations it cannot predict the presence of non-equilibrium hydrocarbon species. However, it is demonstrated in Appendix $\mathrm{D}$ that non-equilibrium hydrocarbons are less flammable that methane and the overall flammability assessment provided by the model will then be conservative.

The composition of the melter feed used in the cold cap model calculations was taken from VSL test reports. In all, the behavior of 7 different melter feed materials was simulated using the cold cap model. The feed compositions were simplified slightly by neglecting trace quantities of materials. For example, the model does not include cesium, iodine and chromium species. The composition of the feeds used in the cold cap model calculations is listed in Appendix B. The table is divided into three sections: the upper section shows components of the waste simulant included in the model composition, the middle section lists glass formers, and the lower section lists the converted organic constituents.

The Chem/Sage multi-stage reactor model of the melter cold cap is illustrated in Figure 2-1. This model, which represents an extension of the four stage conceptual model described in the Task Plan, was developed to give a conservative representation of VSL experimental data. A simpler model where all of the melter feed enters a single stage and reacts to form gas and solid products was unable to accomplish this. Nitrates and nitrites in the feed typically supply sufficient oxygen for complete combustion of organic material and full oxidation of the glass. However, the experimental data consistently shows hydrogen, carbon monoxide and hydrocarbons in the melter gases indicative of incomplete combustion.

Since the Chem/Sage staged reactor model is limited to chemical equilibrium calculations the only way to account for the experimental data is to separate some of the organic feed from the source of oxygen. This was accomplished by feeding $35 \%$ of the hydrocarbons to stages $1-3$ and the remaining $65 \%$ to stage 4 with the nitrates. That is, the experimental data is consistent with about one third of the hydrocarbons in the feed experiencing incomplete decomposition reactions in the cold cap. The gas distribution to upper stages was adjusted through model bypass parameters. These were set to send $25 \%$ of the gas products from each stage to the stage two levels above, $25 \%$ to the stage four levels above and the remaining $50 \%$ directly to the outlet. Therefore, $25 \%$ of the combustion gas from stage 4 , carrying some oxygen, mixes with the hydrocarbon feed to stage 2 while stages 1 and 3 are oxygen starved to simulate pyrolysis of the hydrocarbons.

For physical and chemical reasons it is reasonable to assume that a fraction of the feed material will persist for some distance into the cold cap. For example, nitrates do not decompose until approximately $800^{\circ} \mathrm{C}$ and some of the feed can fall into vent holes and be exposed to higher reaction temperatures. The fraction of feed added to lower levels in the cold cap was used as a modeling parameter to represent reactions occurring over a range of temperatures and better fit the experimental data. 


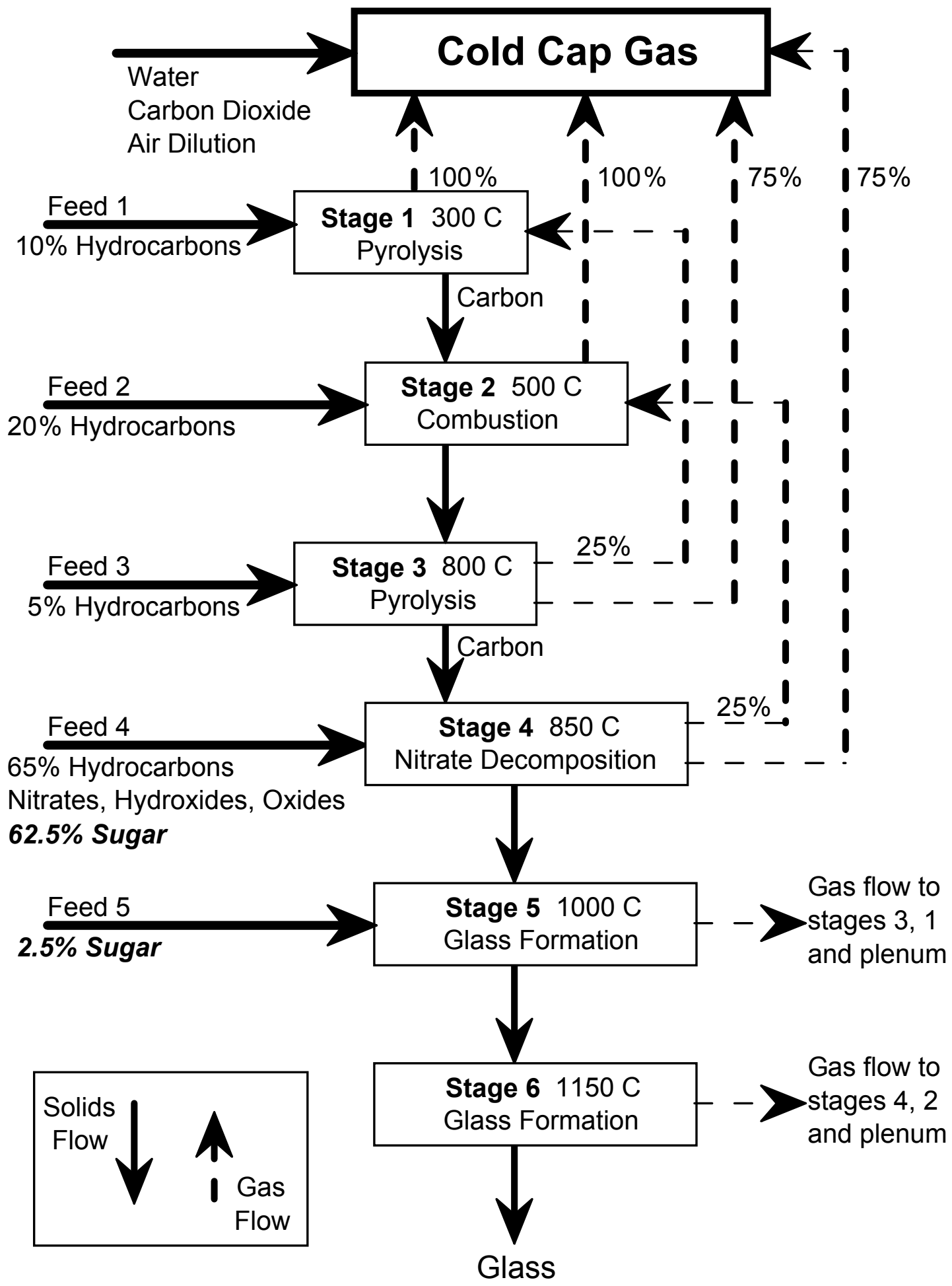

Figure 2-1. Six-stage FACT/Sage Cold Cap Model 
The conceptual model is that Stages 1 and 2 represent hydrocarbon reactions in the upper part of the cold cap as a combination of pyrolysis and partial combustion. Similarly, Stages 3 and 4 represent hydrocarbon reactions at a higher temperature lower in the cold cap. At nominal sugar levels, the hydrocarbons fed to Stage 4 will burn to completion. Stage 3 is included to empirically account for non-ideal effects. As shown in Figure 2-2, which was generated from FACT/Sage equilibrium calculations, pyrolysis of acetic acid at low temperature produces a significant amount of methane while high temperature pyrolysis produces primarily hydrogen and carbon monoxide.

The concept of using two pyrolysis stages in the cold cap model was an attempt to fit the experimental data by adjusting the fraction of hydrocarbon in each stage. In reality the hydrocarbons in the melter plenum decompose by complicated reaction pathways combining partial combustion, pyrolysis under oxygen starved conditions, and non-equilibrium effects. The reactions are occurring at temperatures that are between those of the feed material $(25 \mathrm{C})$ and the glass melt $(1150 \mathrm{C})$. The six-stage cold cap model attempts to represent these effects in as simple a manner and with as few adjustable parameters as possible. The parameters available are distribution of feed materials between reactor stages, stage temperatures and the distribution of gas and solid reaction products from each stage to other stages using "bypass" fractions. The bypass fractions allow the model to distribute gas products from one reactor stage to upper stages. Similarly, solid products from each stage can be distributed to lower stages. The fractions, which must sum to one, specify the fraction of the product that goes to each succeeding stage. Gas bypassing was used to create the pyrolysis stages discussed above while the solid bypassing feature was not used in the model.

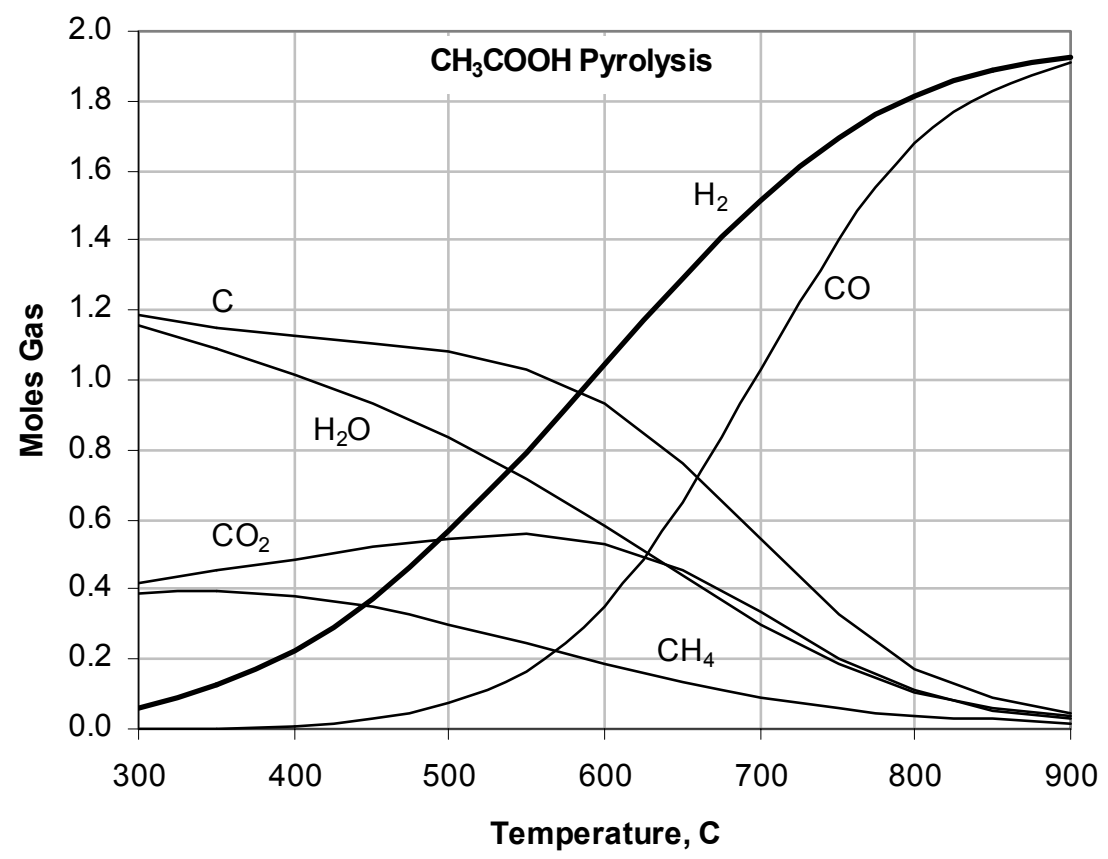

Figure 2-2. Product Distribution from the Pyrolysis of One Mole of Acetic Acid as a Function of Temperature 
VSL experiments have empirically determined that adding 0.75 moles of organic carbon per mole of nitrate plus nitrite successfully controls melter foaming without significantly reducing the glass [Matlack et al., 2003d]. This relationship is used to determine the amount of sugar that must be added to the melter feed and represents the nominal (1X Sugar) case. When sugar in excess of this amount is present in the feed, the model assumes that some of the sugar survives the reactions in the fourth stage and enters the fifth stage where it acts to reduce the glass melt. Model benchmarking determined that splitting the total sugar $62.5 \%$ to Stage 4 and $2.5 \%$ to Stage 5 closely matched existing data on glass redox. Therefore, as shown in Figure 2-1, for model calculations the hydrocarbon feed was distributed as: 10\% to Stage $1,20 \%$ to Stage 2, 5\% to Stage 3 and $65 \%$ to Stage 4 . However, when excess sugar was present, $2.5 \%$ of the sugar was added to Stage 5 instead of Stage 4 . This model construct was used for all of the calculations described in this report.

We note that no experimental data was available measuring cold cap gases when excess sugar was in the feed. The approach taken was to develop model parameters, as described in Section 2.2.1, using offgas data from one DM-10 experiment and glass redox data from a DM-100 experiment. The resulting model was then benchmarked against all other DM-10 and DM-1200 data designed to measure cold cap gas evolution with satisfactory results. However, applying the model to conditions outside of this database necessarily involves some extrapolation. To partially compensate for this lack of data, results obtained from applying the cold cap model to the safety case scenarios were modified before serving as input to the combustion model. This was so that the output from the combustion model better represented more extensive experimental data measuring offgas compositions at the melter exit and downstream in the offgas system.

\subsubsection{Cold Cap Model Development}

Two sets of VSL experimental data were used to develop the cold cap model. These were data collected on the DM10 melter while feeding A1 feed in March 2003 [Matlack et al., 2003d] and data from a set of experiments on the DM100 melter using A3 feed [Matlack et al., 2003c]. These data were selected for model development when it became apparent that A-type feed would give a worst case flammability calculation at increased sugar levels. The A3 DM100 data was also the only data available at variable levels of sugar addition. The DM10 data was collected with the melter plenum partially flooded from high rates of feed addition. This was done to reduce the melter plenum temperature and prevent combustion in the plenum gas space so that the gas generation would be representative of the cold cap reactions. However, it was not possible to achieve steady-state operating conditions using this technique. To use this experimental data we are also forced to assume that the lower gas temperature and atypical melter operation do not significantly change the temperature profile in the reactive part of the cold cap. Water, carbon monoxide, carbon dioxide, oxides of nitrogen, ammonia and other trace gases were measured by FTIR. Hydrocarbons in the offgas were measured using a flame ionization analyzer calibrated for propane. Hydrogen concentrations were measured using gas chromatography, which limited the sampling frequency. 
Since true steady-state operating conditions were not achieved during the DM10 test, it is difficult to compare model predictions of gas generation to the data. The data shows significant variations in the gas concentration during the course of the experiments. Feeding was intermittent and gas generation was suppressed as a thick layer of feed accumulated on the surface of the cold cap. Reviewing the data, episodes of gas surges occurred when a slug of gas breaks through the liquid layer. During the experiments, it was also difficult to maintain a steady plenum temperature. To compensate for the lack of steady-state data, ratios of measured gas concentrations were used as a basis for comparing model predictions to experimental data.

The expectation was that concentration ratios would compensate to some degree for variability in absolute concentration values. All of the hydrogen, nitrogen and carbon in the slurry feed must go into the offgas stream. Nitrogen in the offgas that originates from the feed stream cannot be measured directly because of significant air inleakage to the melter plenum. Similarly, much of the hydrogen exits the melter as water vapor, which is again difficult to measure accurately since it is the largest component of the offgas. Therefore, the most accurate basis is carbon, which is primarily in the form of carbon dioxide. Offgas flammability is determined by the concentrations of hydrogen, carbon monoxide and methane. An assessment of the cold cap model was then based on the following molar ratios:

$$
\mathrm{CO} / \mathrm{CO}_{2}, \mathrm{H}_{2} /\left(\mathrm{CO}_{2}+\mathrm{CO}\right), \mathrm{CH}_{4} /\left(\mathrm{CO}_{2}+\mathrm{CO}\right) \text { and } \mathrm{NH}_{3} /\left(\mathrm{CO}_{2}+\mathrm{CO}\right)
$$

The experimental data shows that the concentration of carbon dioxide, the predominant carbon carrier, in the offgas varies significantly over the duration of each test. While, all of the carbon in the feed must eventually appear in the offgas, at any one time it is difficult to obtain an accurate carbon balance. The molar ratios were used to correct for some of this variation.

As noted above, the distribution of nitrogen compounds in the model offgas is unlikely to be accurate since the model was unable to include for the formation of nitrogen gas which the data suggests accounts for about $60 \%$ of the nitrogen in the feed. Nevertheless, ammonia was considered in the model assessment since it was a significant component in the data. The combustion model described in Section 2.3 adjusts the nitrogen compound distribution to correct for this deficiency in the cold cap model.

Figure 2-3 through Figure 2-6 compare model predictions of the cold cap gas ratios with the experimental data from DM10 tests with A1 feed. In all cases, the model prediction is a constant value shown as a line across the graph while the experimental data is plotted as individual points. The three intervals of melter feeding during the experiment are marked on each figure.

Figure 2-3 shows the cold cap model prediction of the molar ratio of carbon monoxide to carbon dioxide compared to data obtained during DM10 tests with the A1 feed composition. The model prediction is very close to the observed maximum ratio. 
WSRC-TR-2003-00285, REVISION 0

SRT-RPP-2003-00130, REVISION 0

Figure 2-4 shows a similar comparison for moles of hydrogen gas per mole of carbon dioxide plus carbon monoxide. Again the model conservatively predicts the hydrogen ratio falling below only two data points that are clearly much larger than the other values and likely are the result of gas surges.

Figure 2-5 compares the model prediction of moles ammonia to moles carbon for this feed composition compared to experimental data. As for the other results, except for a few high data points, the model predicts the maximum ammonia ratio with good accuracy. Note that both the maximum hydrogen and ammonia levels occur simultaneously at about 2.5 hours and likely result from a gas surge.

Figure 2-6 shows the moles of methane to moles of carbon dioxide and carbon monoxide measured and predicted by the model. Since the flame ionization detector was calibrated for propane, the measured hydrocarbon concentrations in Figure 2-6 have been multiplied by a factor of three to convert them into an equivalent concentration of methane in the offgas. In this case, the model predicts about the average concentration rather than the maximum. Attempts to increase the model predicted methane concentration while maintaining the hydrogen and carbon monoxide concentrations at conservative levels were not successful and this result was accepted as adequate model validation.

In general, for the A1 feed composition, the model predicts gas compositions near peak values except for one episode that is clearly a surge event. The DM10 experiments were conducted by over-feeding the melter, which partially flooded the plenum, followed by cold cap burn off and then a resumption of feeding. From the manner in which the experiments were run, one would expect offgas composition to rise to values representative of cold cap gas evolution as feeding starts and then decline as the melter flooded. This behavior does appear to occur in the carbon monoxide data but not in the other gas data. Some of the experimental peaks may be caused by gas surges through the feed layer so tuning the model to match these peak values is conservative. 
WSRC-TR-2003-00285, REVISION 0

SRT-RPP-2003-00130, REVISION 0

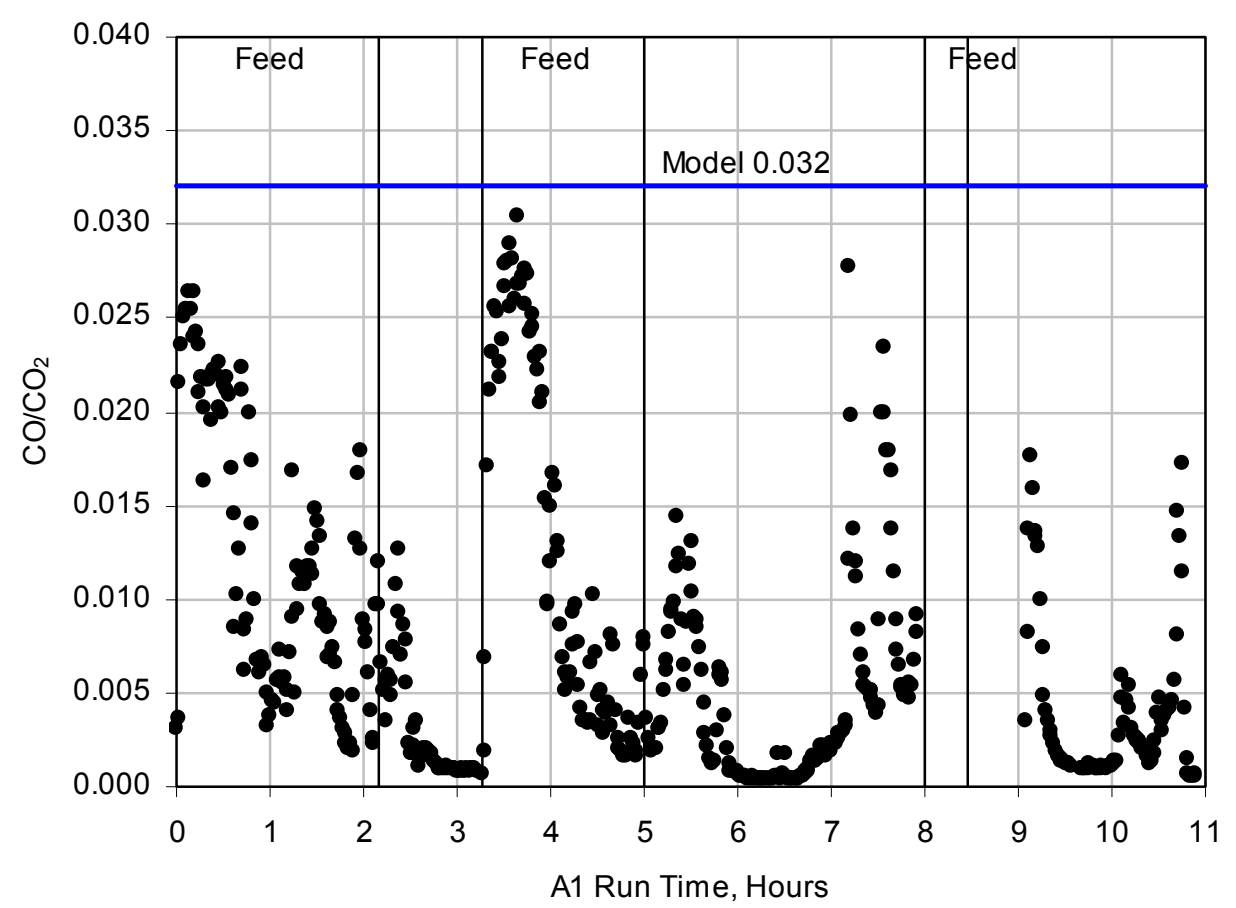

Figure 2-3. Model prediction of carbon distribution compared to DM10 experimental data with A1 feed

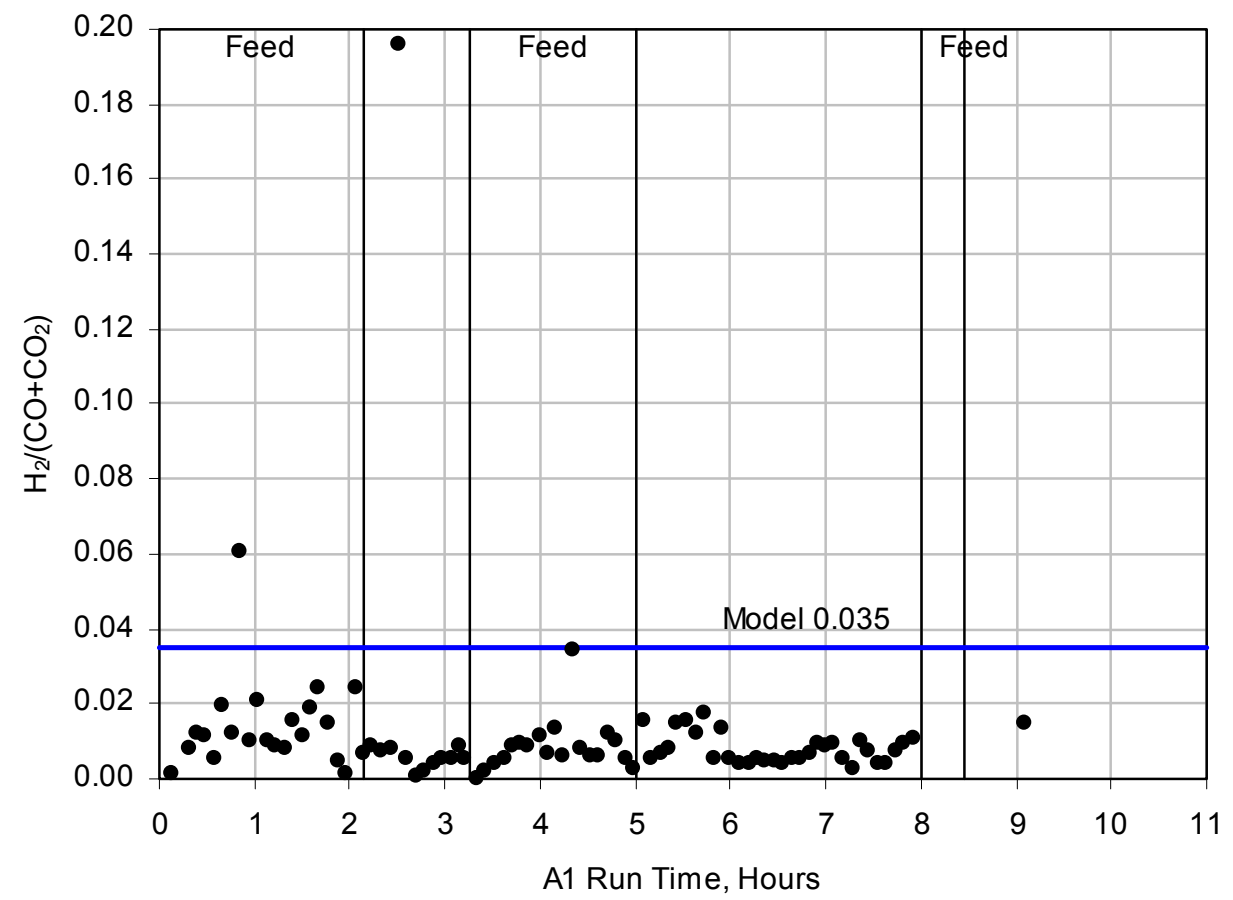

Figure 2-4. Model prediction of hydrogen production compared to DM10 experimental data with $\mathrm{A} 1$ feed 


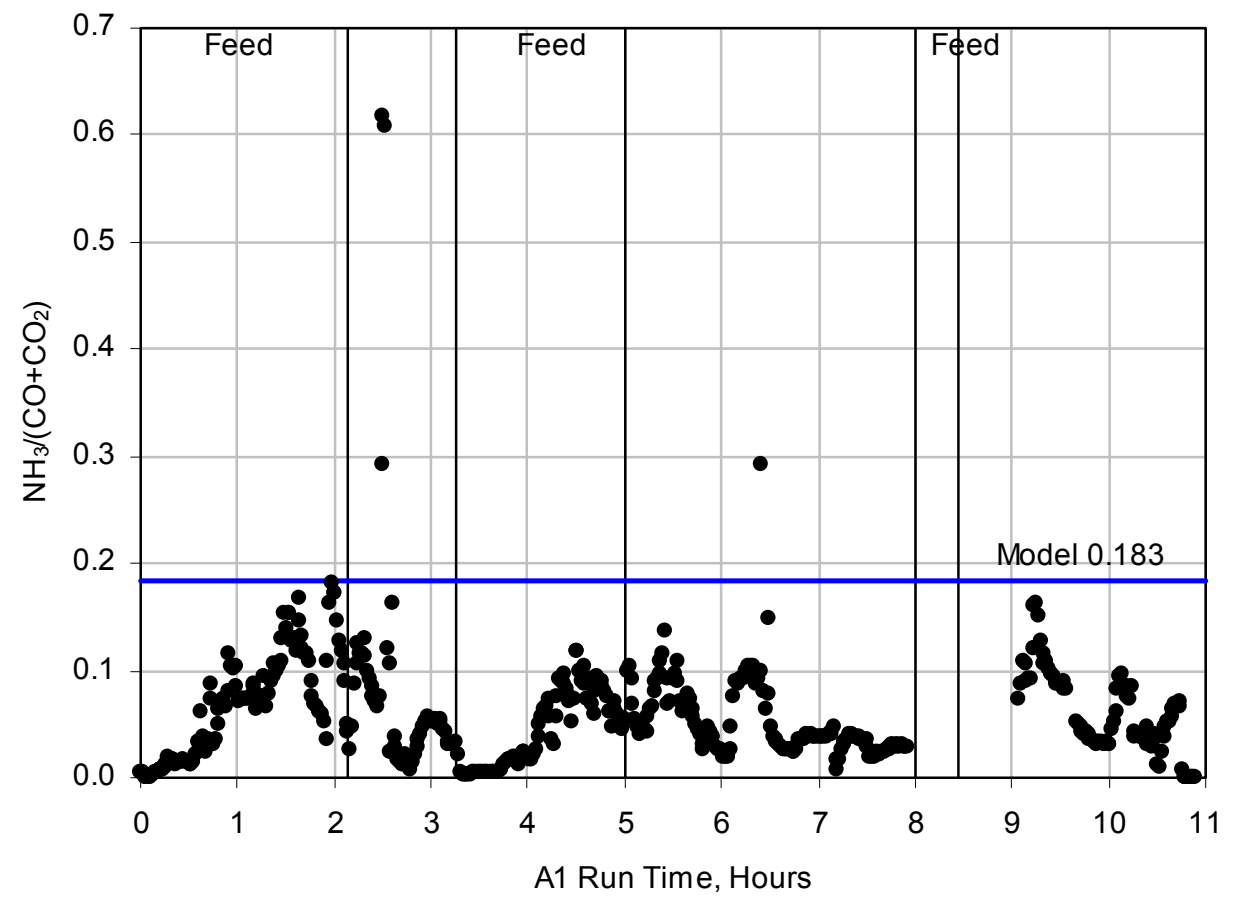

Figure 2-5. Model prediction of ammonia production compared to DM10 experimental data with $\mathrm{A} 1$ feed

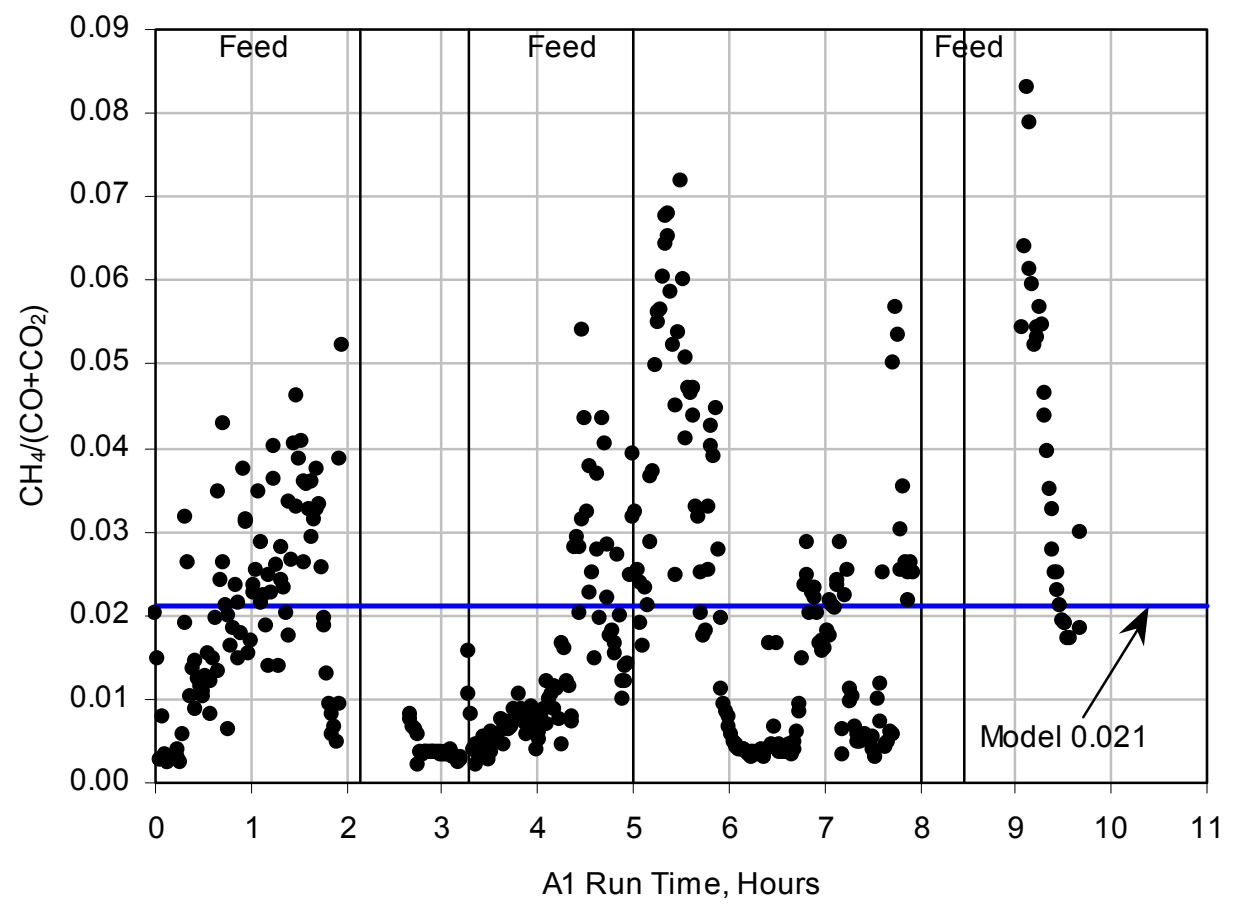

Figure 2-6. Model prediction of methane production compared to DM10 experimental data with A1 feed 
The A1 data set from the DM10 run was used for model development, and the feed distribution, that is the hydrocarbon split between stages $1-4$ shown in Figure 2-1, and the temperatures of stages 1 and 3 were adjusted to obtain these results. One additional data set from A3 feed in the DM100 melter was also used to adjust the cold cap model. This experiment added sugar to the feed at 1, 1.5, 2 and 2.5 times the nominal level.

The melter offgas composition was not measured under conditions that would represent cold cap gas evolution. However, glass redox at the various sugar levels was measured. It was found that if $2.5 \%$ of the sugar was added to Stage 5 of the cold cap model when excess sugar was present in the feed, the model glass composition matched the measured redox levels very closely. This is shown in Figure 2-7, which plots measured and predicted glass redox against the sugar level.

The model calculation was extended to 3 times the nominal sugar level to see if the linear trend continued at higher sugar levels. The data and model results can be fit very closely to a linear response over the range tested. For information, model predictions of cold cap gas generation in moles of gas produced per $100 \mathrm{~kg}$ feed are shown in Figure 2-8 as a function of sugar level.

The sugar level is plotted as a multiple of the nominal amount from 1 to 3 . Model predictions of the relative changes in gas composition are in good agreement with the experimental data reported in Table 5.6 in VSL-01R62N0-1 [Matlack et al., 2003c]. Doubling the sugar, the data shows a $6 \mathrm{X}$ increase in $\mathrm{CO}, 2 \mathrm{X}$ increase in $\mathrm{NH}_{3}$ and a decrease in $\mathrm{NO}_{\mathrm{x}}$ by a factor of $1 / 2$ while the model predicts changes of $5 \mathrm{X}, 2 \mathrm{X}$ and $1 / 4$, for $\mathrm{CO}, \mathrm{NH}_{3}$ and $\mathrm{NO}_{\mathrm{x}}$, respectively. 
WSRC-TR-2003-00285, REVISION 0

SRT-RPP-2003-00130, REVISION 0

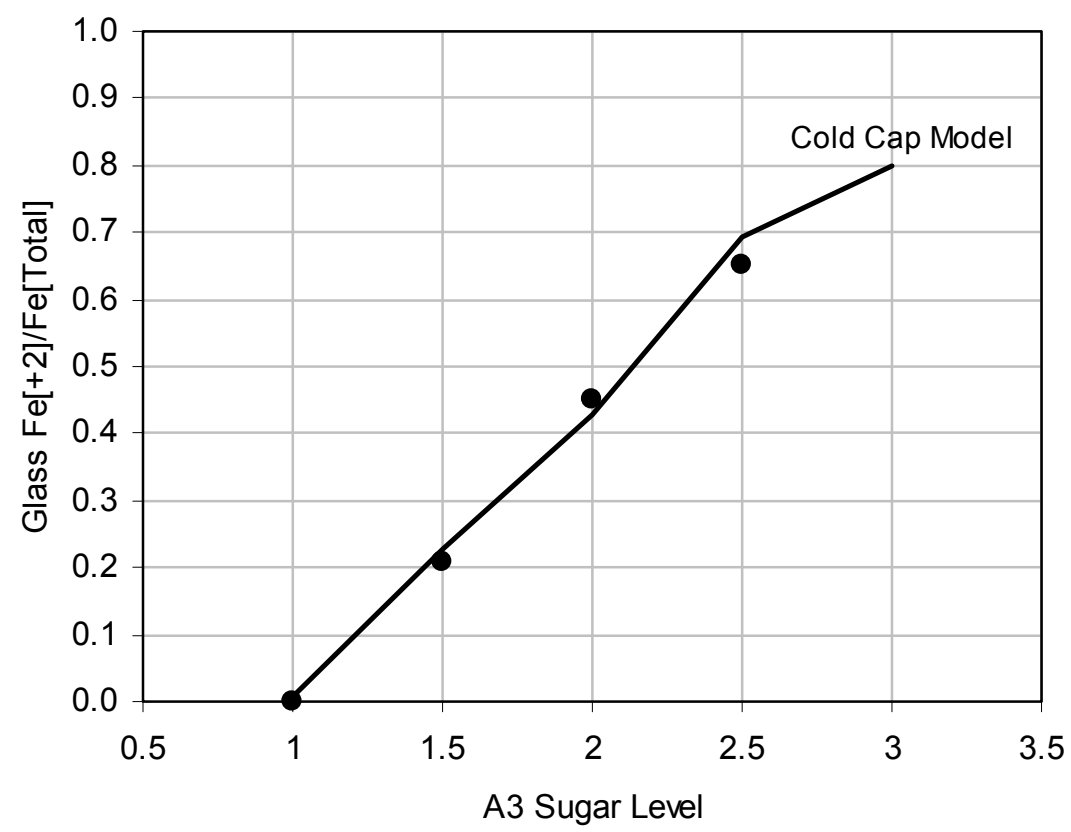

Figure 2-7. Benchmarking of cold cap model feed distribution at elevated sugar levels against DM100 experimental data on glass redox with A3 feed

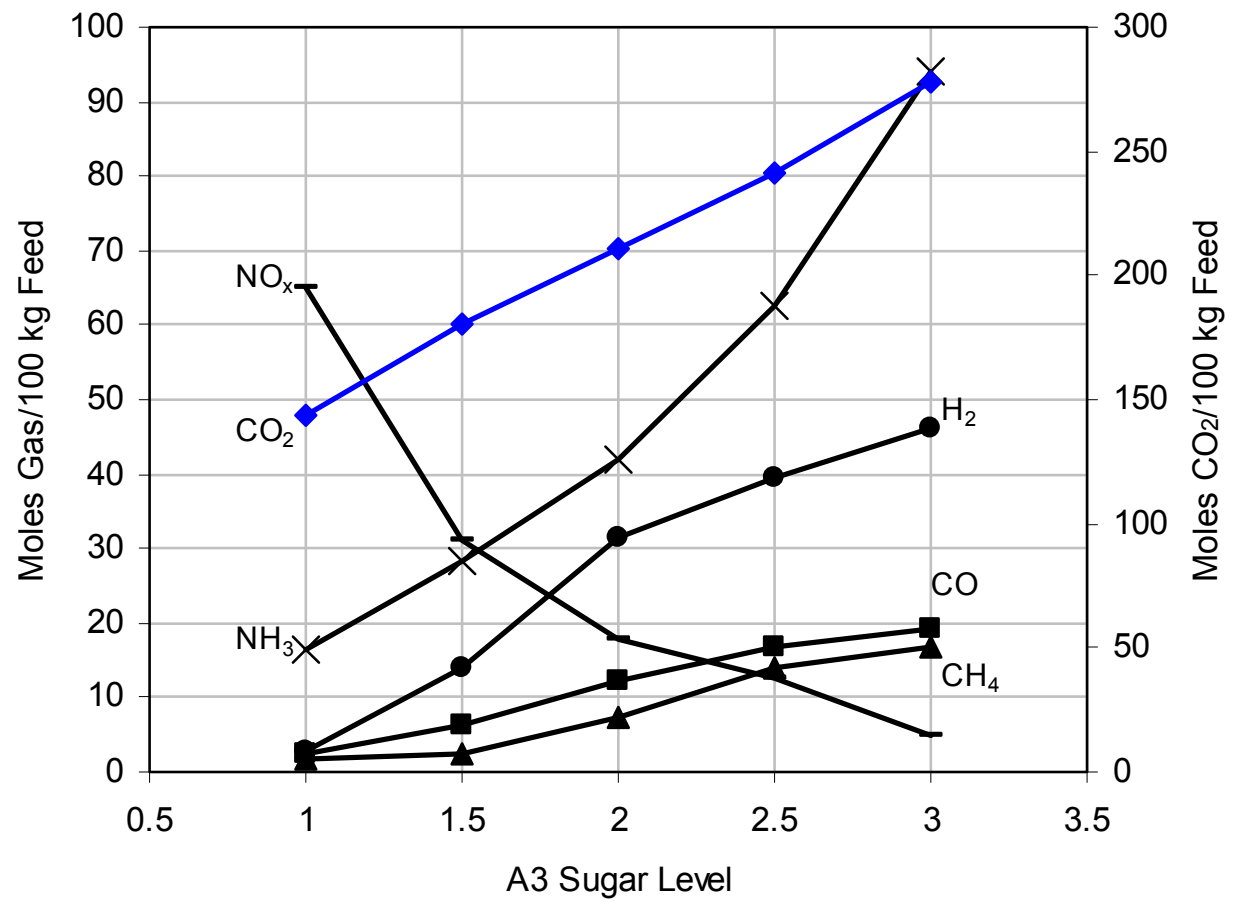

Figure 2-8. Cold cap model prediction of offgas generation as a function of sugar level with $\mathrm{A} 3$ feed 


\subsubsection{Cold Cap Model Validation}

Three sets of VSL offgas data were used to validate the cold cap model. These data were two sets collected on the DM10 melter with C2 [Matlack et al., 2003d] and A2 feed [Matlack et al., 2003b] and data collected on the DM1200 melter using a special gas sampling probe while running B1 feed [Matlack et al., 2003b]. Figure 2-9 through Figure 2-12 show comparisons of model predictions to experimental data for the $\mathrm{C} 2$ feed, Figure 2-17 through Figure 2-20 show the same comparisons for the A2 feed, and Figure 2-21 through Figure 2-24 for the B1 feed. In all of these plots, the model prediction is a constant indicated by the line across the graph while the experimental data is plotted as points. The model described above and illustrated in Figure 2-1 was used for all of the calculations with only the feed composition changed to match that of the simulant used in each experiment. Feed $\mathrm{C} 2$ contained enough organic material in the simulated waste that no sugar was required. This case then provides a good test of the cold cap model under conditions significantly different from the development case.

In general, the results obtained with $\mathrm{C} 2$ feed are similar to those found with $\mathrm{A} 1$ feed. As shown in Figure 2-9 through Figure 2-11, the model predicts $\mathrm{CO}, \mathrm{H}_{2}$ and $\mathrm{NH}_{3}$ ratios that do not exceed the peak values, but do fall near the high end of the experimental data. In particular, the hydrogen value falls above about $67 \%$ of the data points. All the data show peaks just after the three feeding intervals which indicate gas surges. During surges, the gas composition may have different characteristics than during periods of steady gas evolution from the cold cap. The model is intended to predict steady gas evolution from the cold cap with the effect of gas surges to be applied separately. Since steady-state operating conditions were not achieved during the experiment, the model results provide sufficiently conservative predictions of the $\mathrm{CO}$ and $\mathrm{H}_{2}$ gas composition. Figure 2-12 shows that the model underpredicts methane generation.

In Figure 2-13 through Figure 2-16, predictions of actual gas concentrations in the offgas based on cold cap model calculations with $\mathrm{C} 2$ feed are compared to measured values. Calculating a gas concentration from the model output requires estimating air inleakage into the plenum. This introduces additional uncertainty into the calculation which is eliminated by comparing the molar ratios. From the experimental data, an average air flow of 577 moles/hr was estimated during the $\mathrm{C} 2$ experiment. The melter was fed during the three time intervals indicated on the plots with the feed rate increasing in each of the intervals. This change in feed rate is reflected in the step changes in the model concentration predictions. The model assumes steady-state operation and continuous feeding at the experimental rate. However, in several cases the maximum gas concentration was not observed during melter feeding so the model prediction is extended until the next feed interval is reached. On the basis of absolute concentration, model predictions are conservative. With the exception of an apparent gas surge at the end of the first feeding interval, model prediction of gas concentrations for the four flammable gases are all above the measured concentrations. In particular, all of the hydrogen data is bounded. 


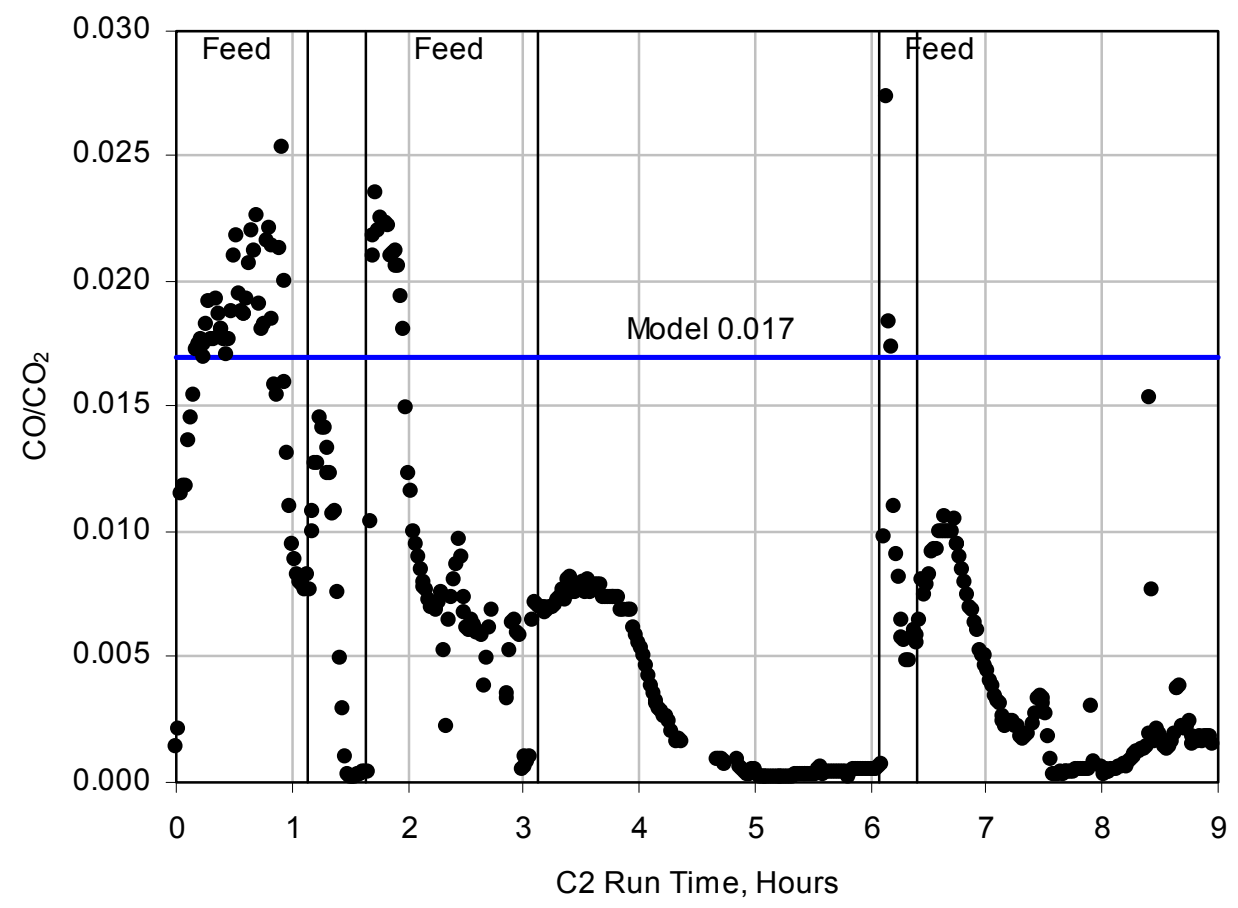

Figure 2-9. Model prediction of carbon distribution compared to DM10 experimental data with $\mathrm{C} 2$ feed

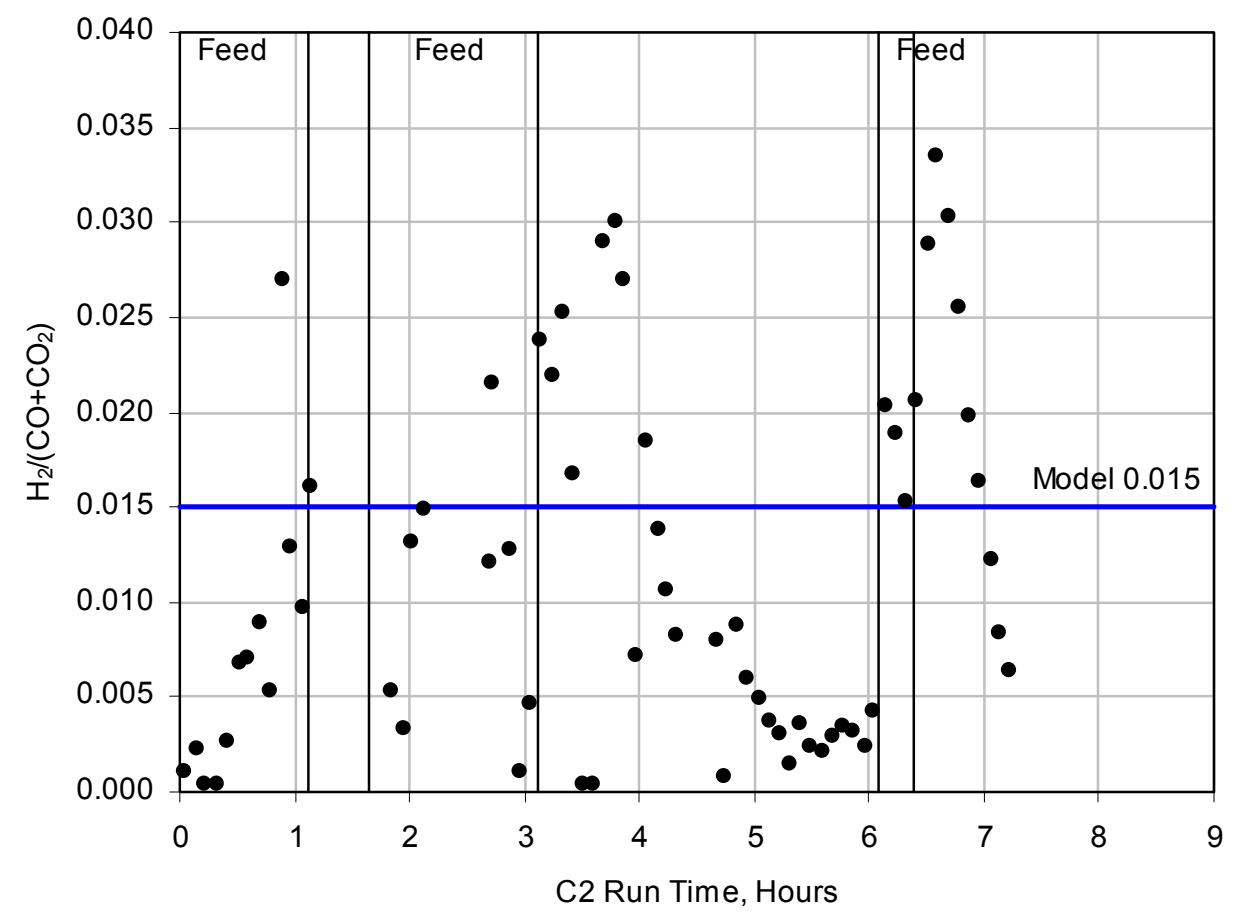

Figure 2-10. Model prediction of hydrogen production compared to DM10 experimental data with $\mathrm{C} 2$ feed 


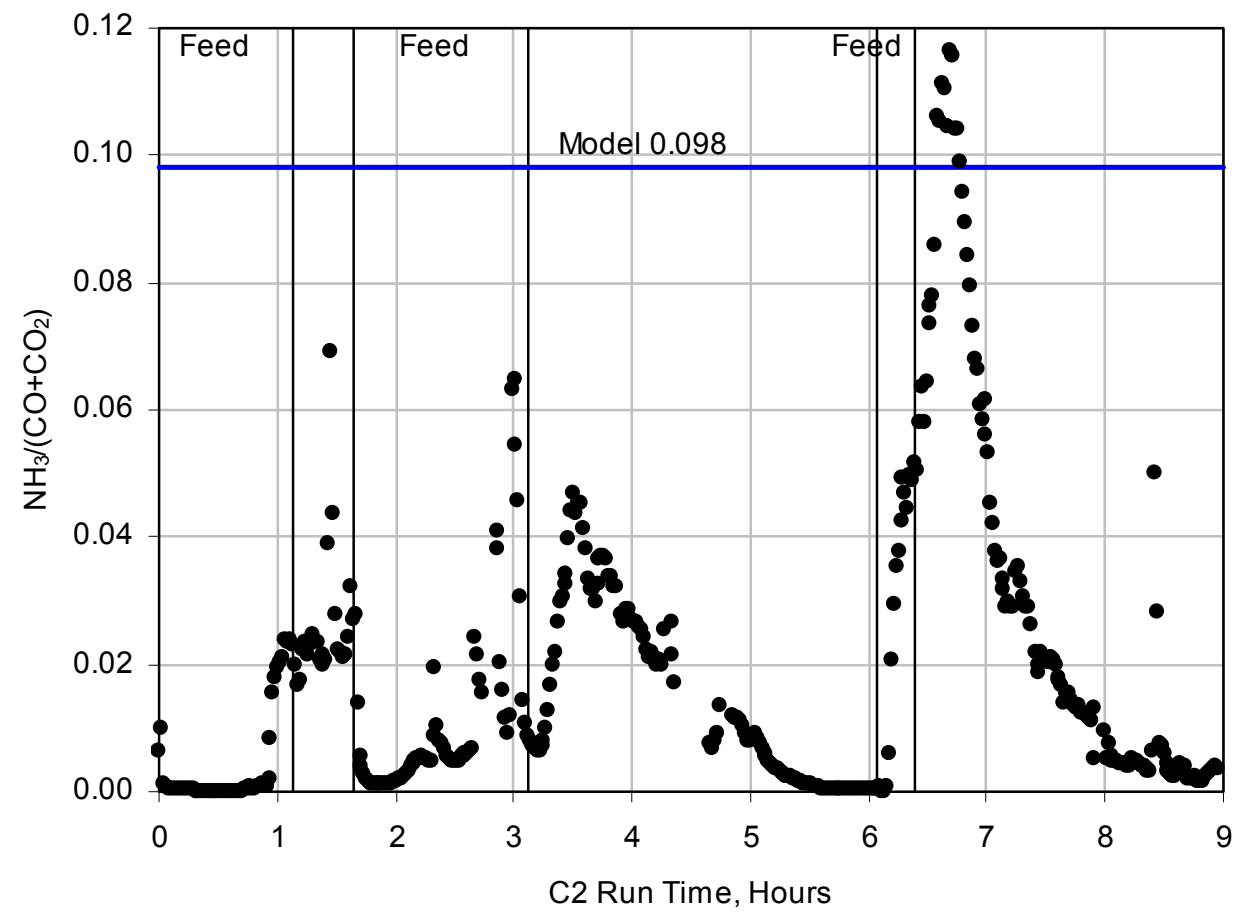

Figure 2-11. Model prediction of ammonia production compared to DM10 experimental data with $\mathrm{C} 2$ feed

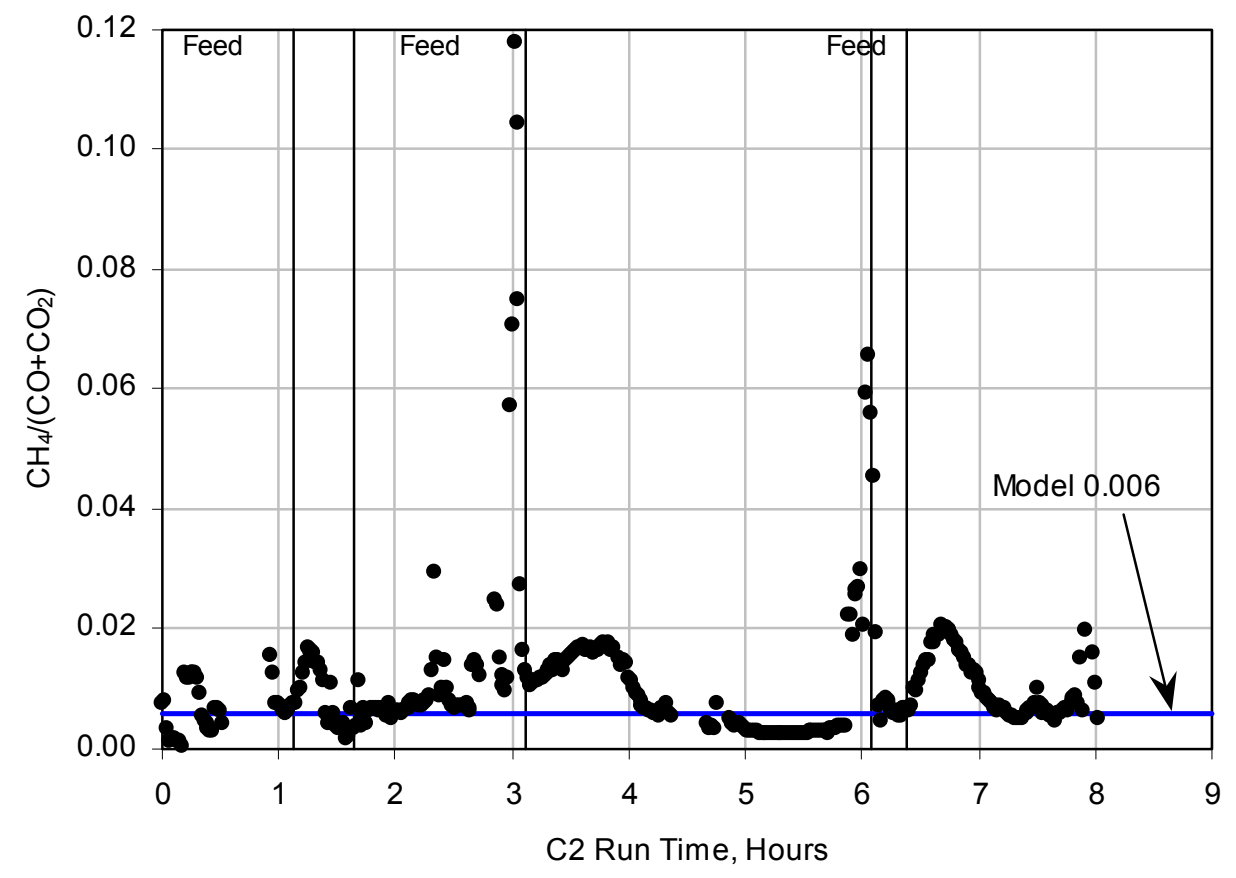

Figure 2-12. Model prediction of methane production compared to DM10 experimental data with $\mathrm{C} 2$ feed 
As might be expected from the similarity in the feed composition, the results obtained with the A2 feed are closer to the A1 results. As shown in Figure 2-17 through Figure 2-20, the model consistently predicts near maximum ratios of carbon monoxide, hydrogen and ammonia for the A2 feed. Figure 2-18 shows that hydrogen data from this experiment is very limited. The two peak hydrogen values likely represent gas surges as evidenced by corresponding peaks in the ammonia and carbon monoxide levels. An exception to the good agreement with A2 results is that hydrocarbon measured in the gas during the A1 DM10 experiment is significantly under-predicted by the model as shown in Figure 2-20. The hydrocarbon was measured as propane and converted to the equilavent amount of methane for the model comparison.

The DM1200 experimental data plotted in Figure 2-21 through Figure 2-24 was obtained under conditions quite different from the DM10 runs. In this case, the DM1200 was operated at near steady-state conditions removing a large source of variation present in the DM10 data. The gas was sampled directly from the melter plenum using a special probe. Two sets of samples were obtained, one set at a lower feed rate between 0 and 0.9 hours and a second set at a higher feed rate plotted between 1.0 and 1.6 hours on the graphs. Actually the second data set was obtained several days after the first. One hour was added to the sampling time for the second data set so that it could be conveniently shown on the same plot as the first set. Probe samples were taken at different heights in the plenum gas space at 20 minute intervals during the first data collection period. These data are indicated as the 28 ", 14 " and 0 " sets in the figure. The data at 0 " is with the sample probe resting on the cold cap. During the second data collection period, the gas was only sampled at the cold cap surface.

The model does a reasonable job of predicting the measured B1 data. In Figure 2-21, the data shows an increase in the relative amount of carbon monoxide produced during the second B1 test. The model predicts near the average value of this data and gives a conservative prediction for the carbon monoxide measured during the first test period. As shown in Figure 2-22, the model also gives a conservative prediction of the measured hydrogen gas generation based on the limited data available. The model predicts significantly more ammonia than is measured (Figure 2-23) except during the sampling at the cold cap surface in the first test period. Predictions of methane (Figure 2-24) are close to the average measured value but, as with the other cases, fall below typical peak values by a factor of about 5 . There is concern that, despite cooling, gases continued to react in the sample probe producing lower measured values of hydrogen, ammonia and carbon monoxide than were actually present in the plenum gas. This effect was evident during an experiment using a similar probe technique to sample plenum gases on a test melter at SRTC. Therefore, the model predictions may not be as conservative as indicated by this data and model validation does not rely heavily on the B1 data comparisons. 
Confidence in the ability of the cold cap model to predict gas releases is obtained from these model validation studies. It should be noted that the glass product in all of these experiments was essentially fully oxidized. The cold cap model predicted $\mathrm{Fe}[+2] / \mathrm{Fe}[$ total $]$ ratios between 0.03 and 0.006 for these experiments. While this result agrees with the experimental data it does not provide good model validation since all of the results are small values. However, without modification, the model is able to give reasonable predictions for experimentally measured calcine gas compositions collected on different melter configurations with different feed compositions. Model parameters have been adjusted to give an appropriately conservative prediction of the cold cap offgas composition. Additional conservatism is introduced in the combustion calculations described in Section 2.3. 
WSRC-TR-2003-00285, REVISION 0

SRT-RPP-2003-00130, REVISION 0

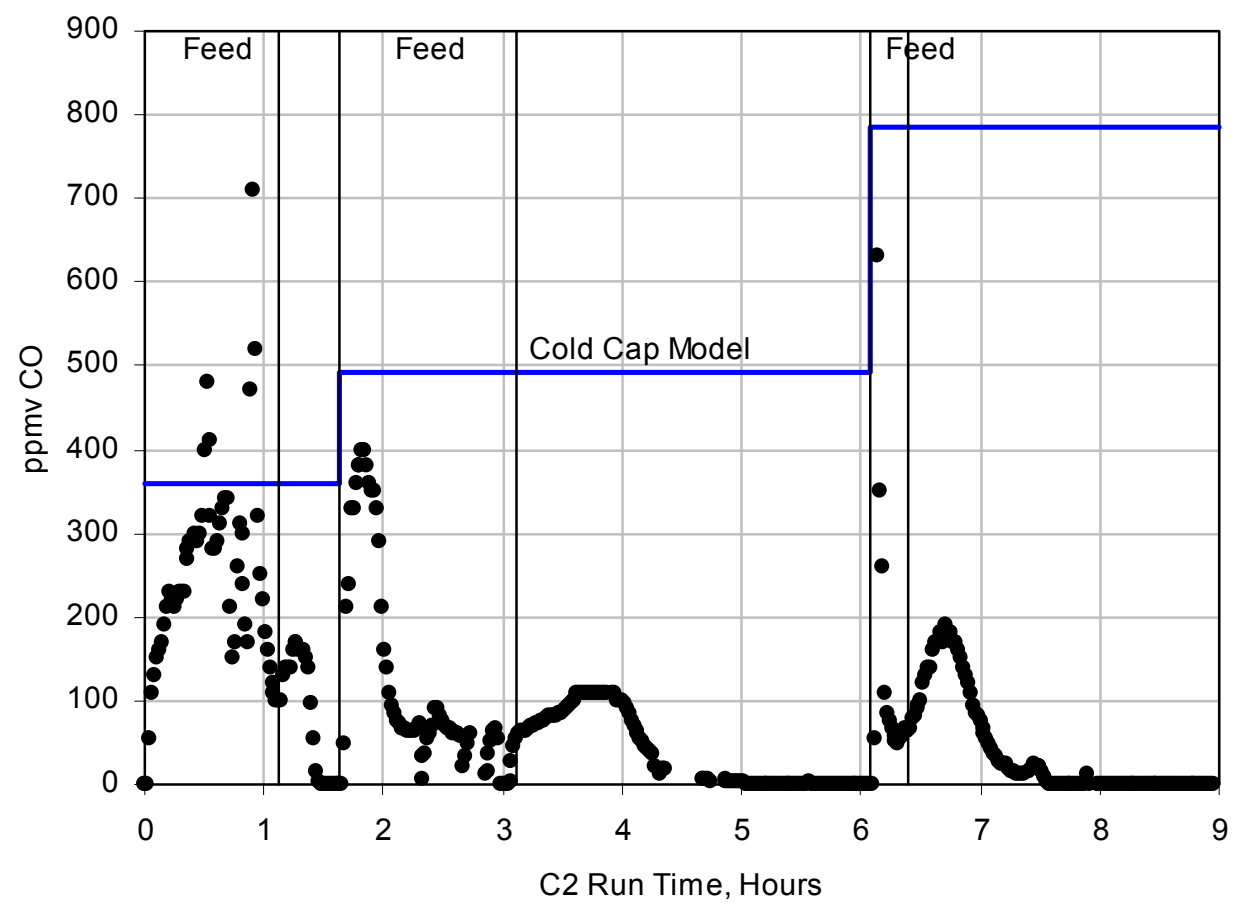

Figure 2-13. Model prediction of carbon monoxide concentration in cold cap offgas compared to DM10 experimental data with $\mathrm{C} 2$ feed

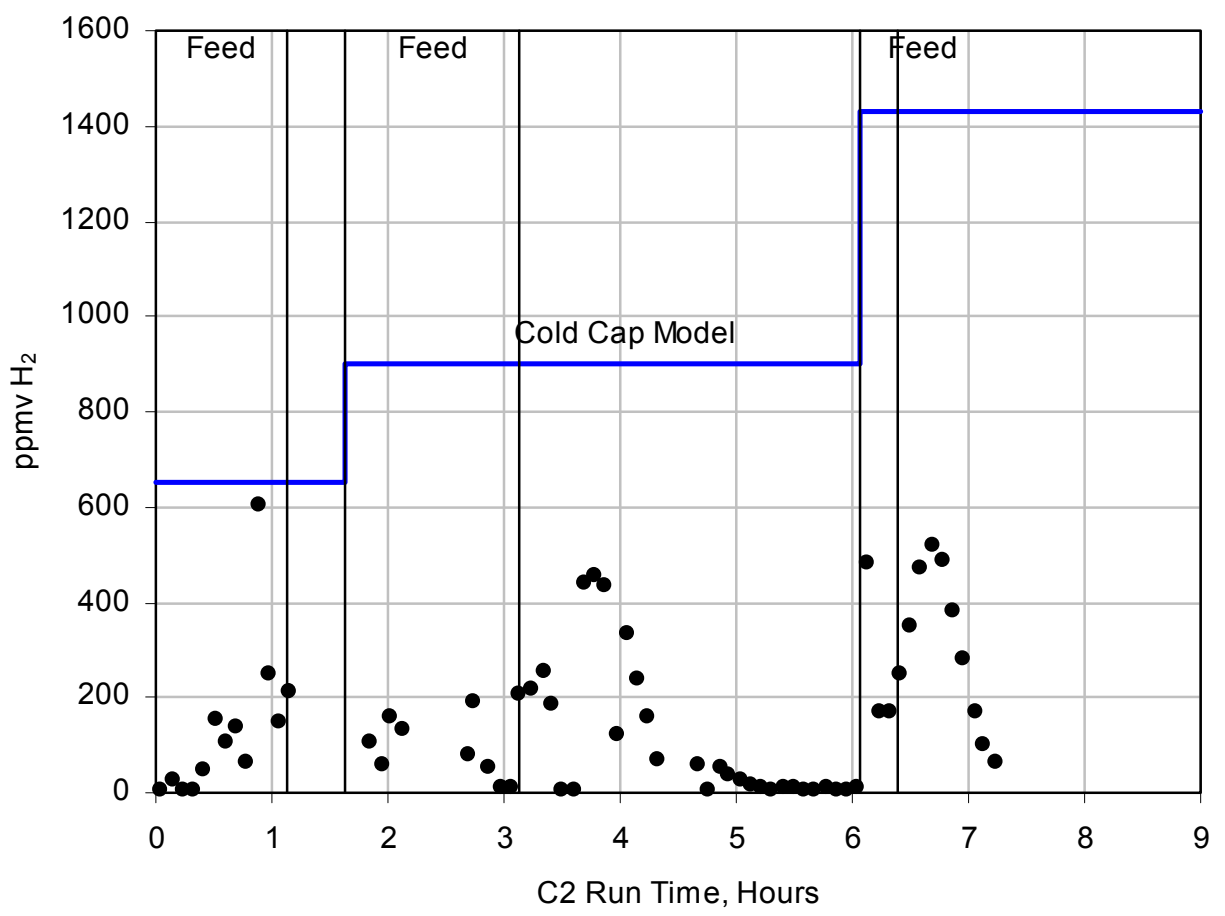

Figure 2-14. Model prediction of hydrogen concentration in cold cap offgas compared to DM10 experimental data with $\mathrm{C} 2$ feed 


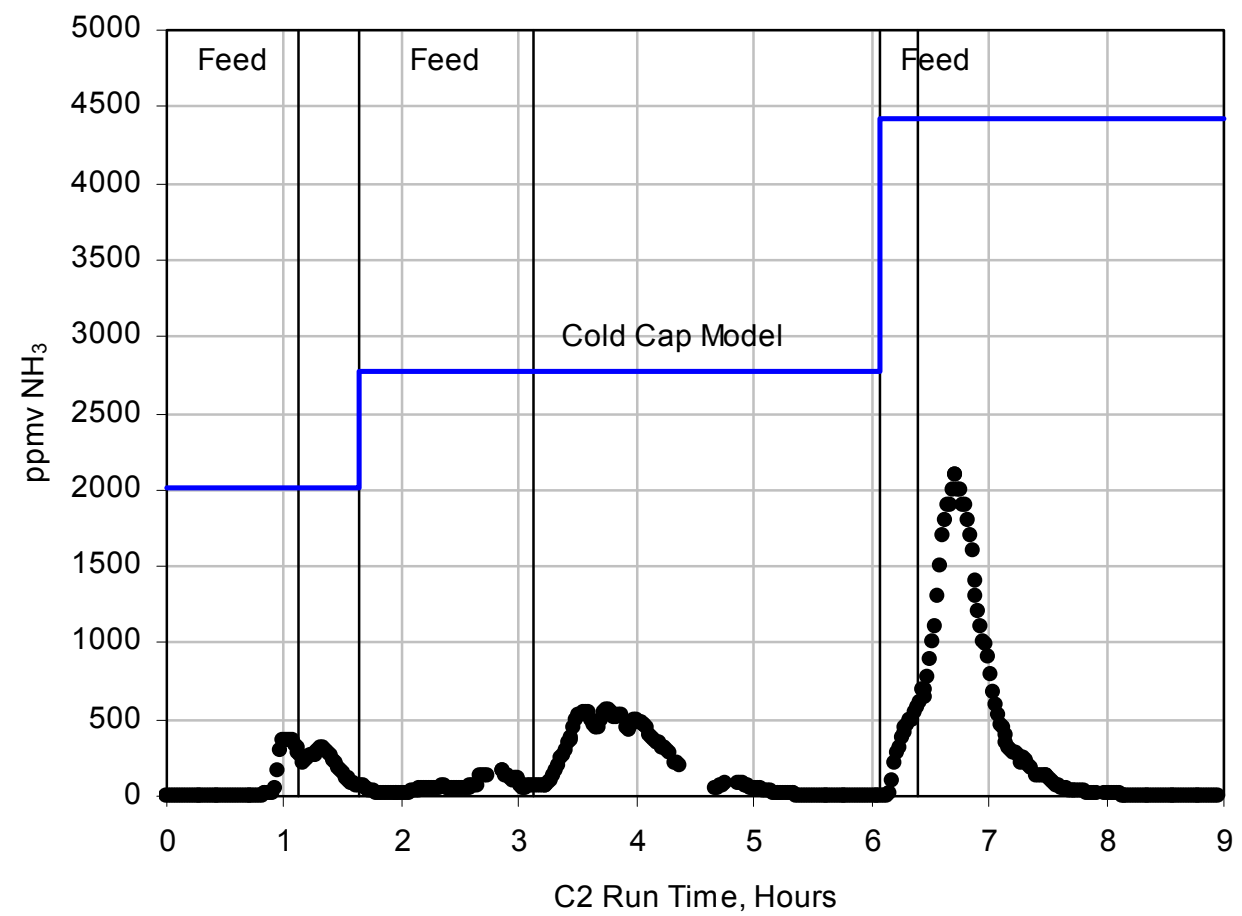

Figure 2-15. Model prediction of ammonia concentration in cold cap offgas compared to DM10 experimental data with $\mathrm{C} 2$ feed

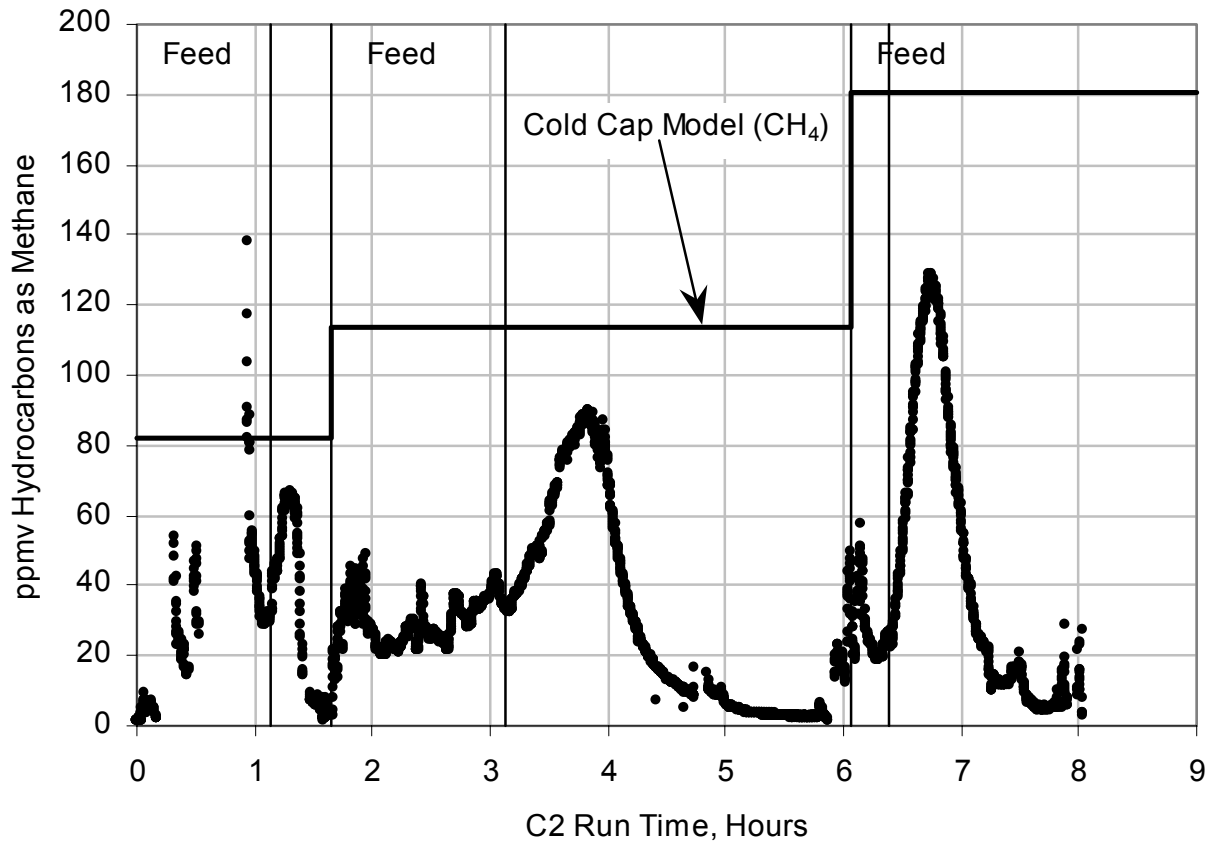

Figure 2-16. Model prediction of methane concentration in cold cap offgas compared to DM10 experimental data with $\mathrm{C} 2$ feed 
WSRC-TR-2003-00285, REVISION 0

SRT-RPP-2003-00130, REVISION 0

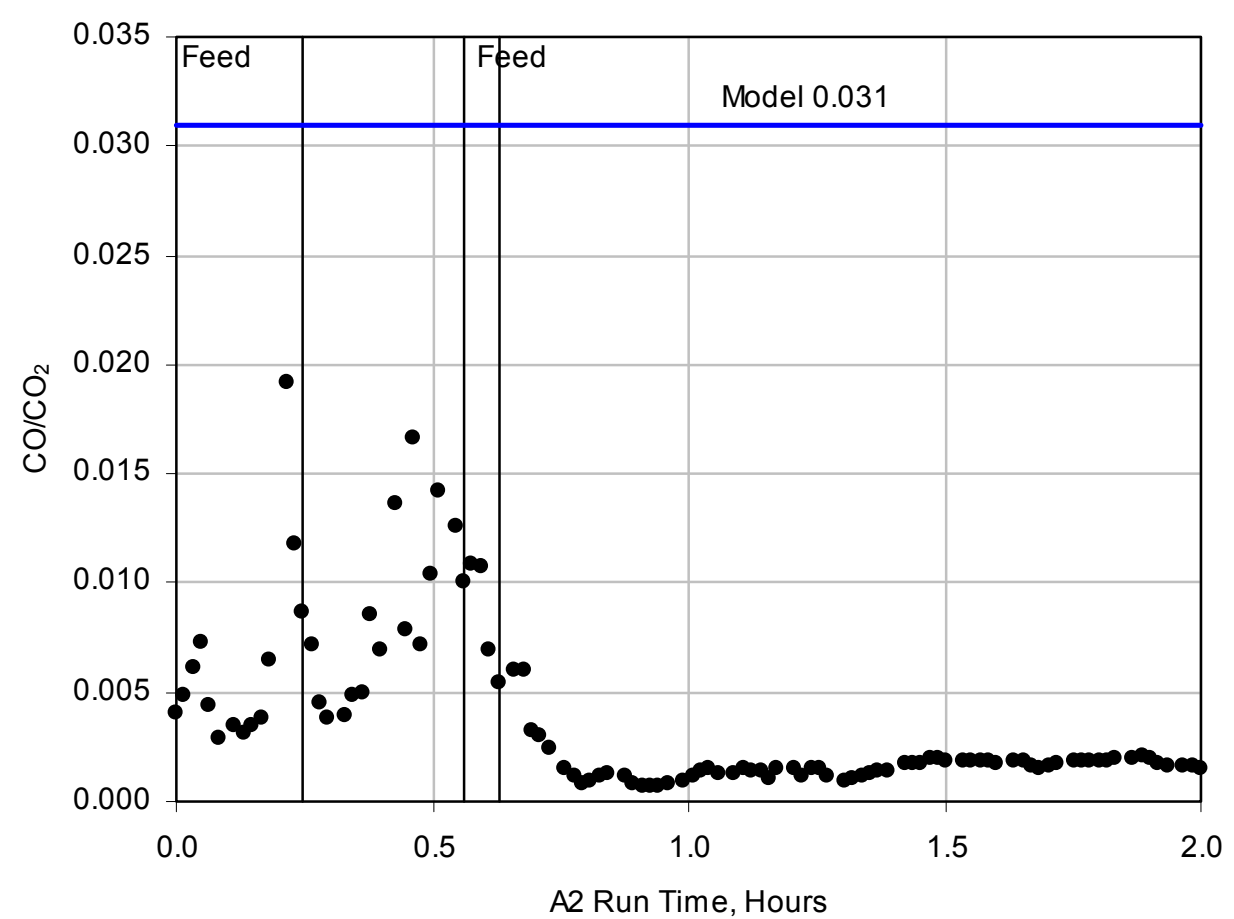

Figure 2-17. Model prediction of carbon distribution compared to DM10 experimental data with A2 feed

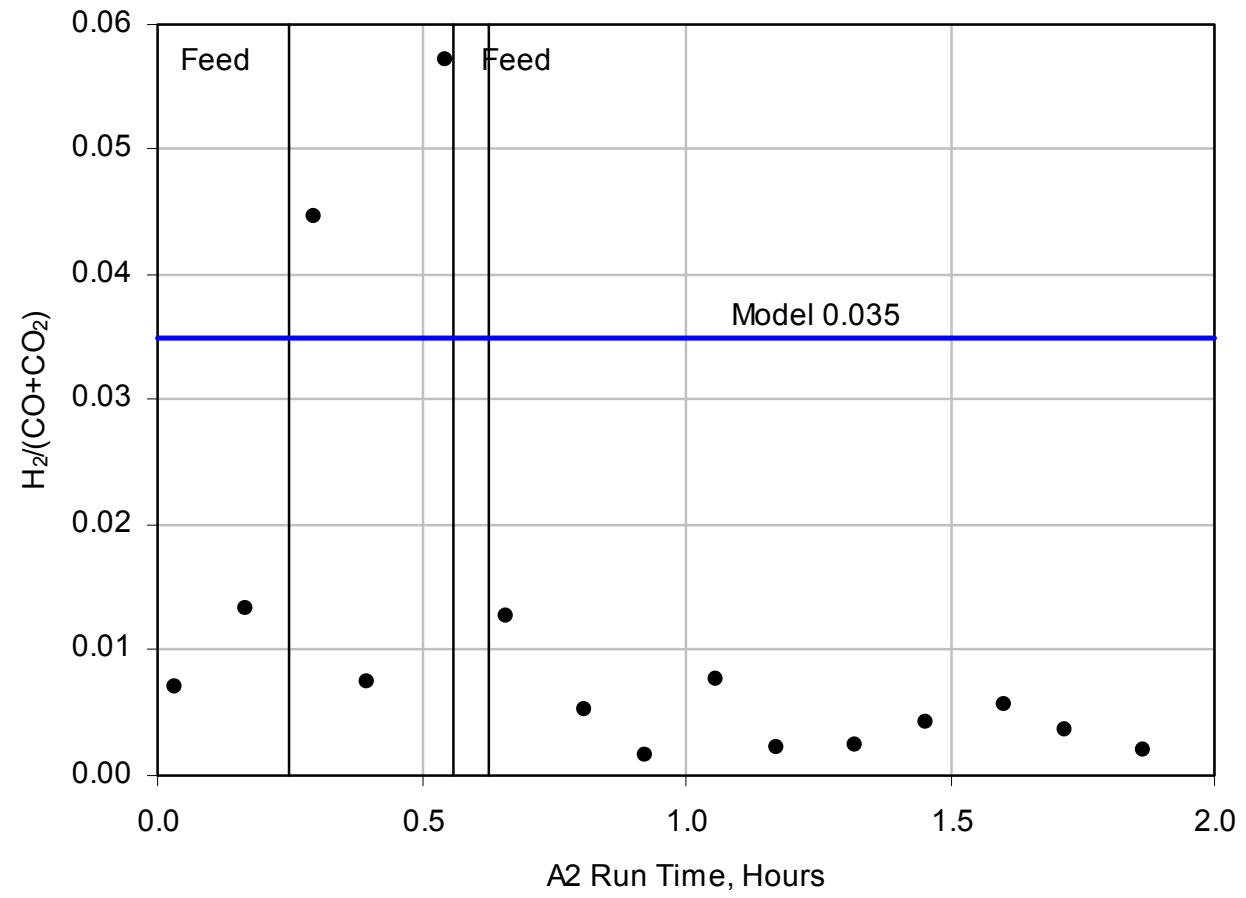

Figure 2-18. Model prediction of hydrogen production compared to DM10 experimental data with $\mathrm{A} 2$ feed 
WSRC-TR-2003-00285, REVISION 0

SRT-RPP-2003-00130, REVISION 0

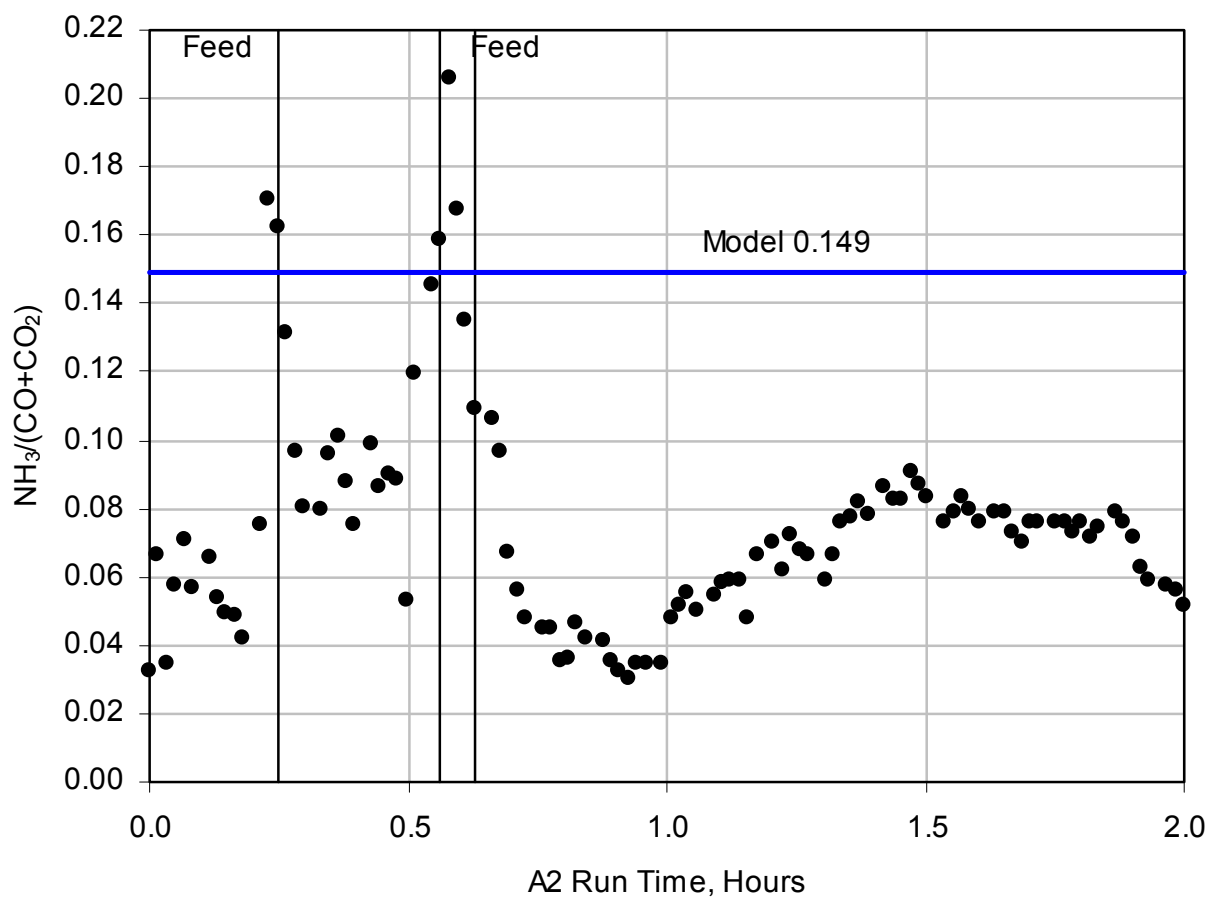

Figure 2-19. Model prediction of ammonia production compared to DM10 experimental data with $\mathrm{A} 2$ feed

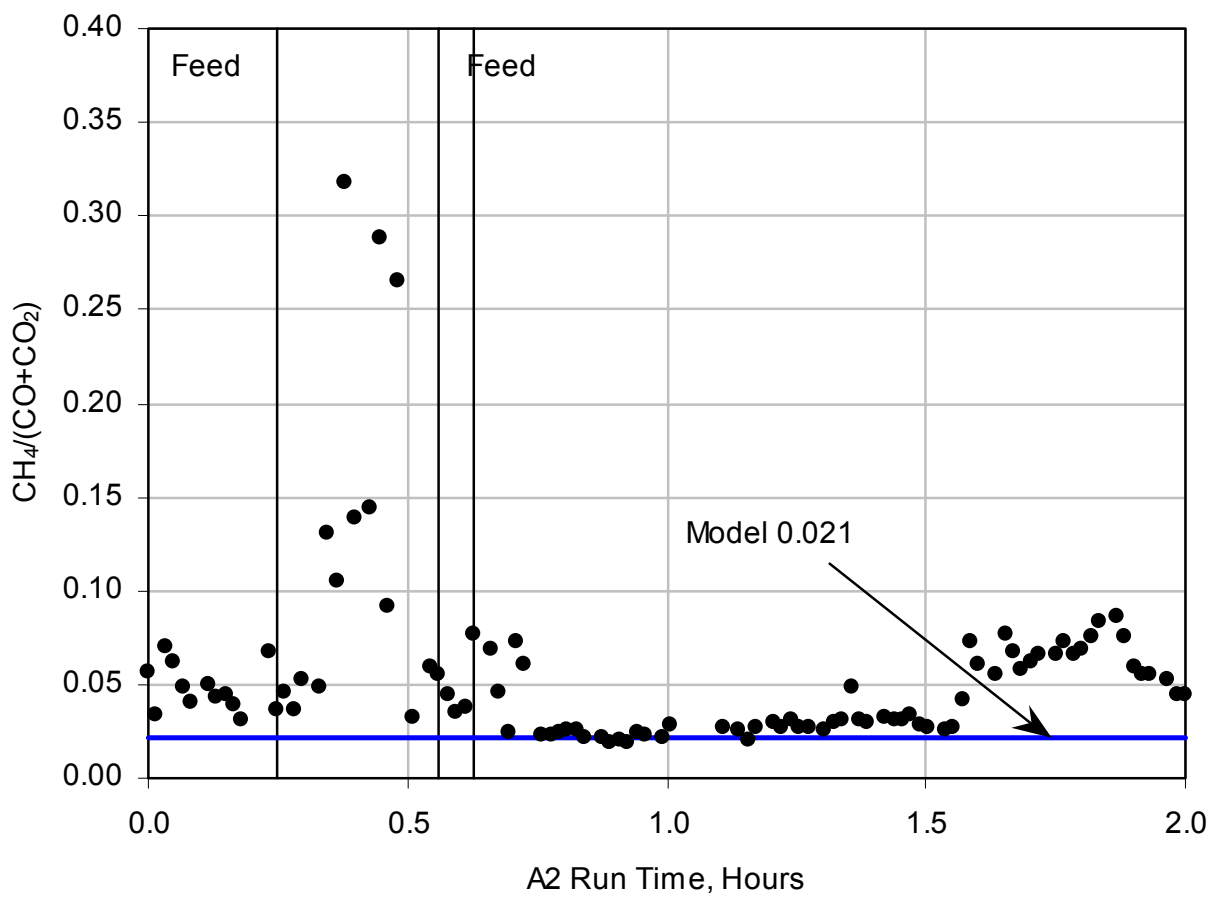

Figure 2-20. Model prediction of methane production compared to DM10 experimental data with $\mathrm{A} 2$ feed 
WSRC-TR-2003-00285, REVISION 0

SRT-RPP-2003-00130, REVISION 0

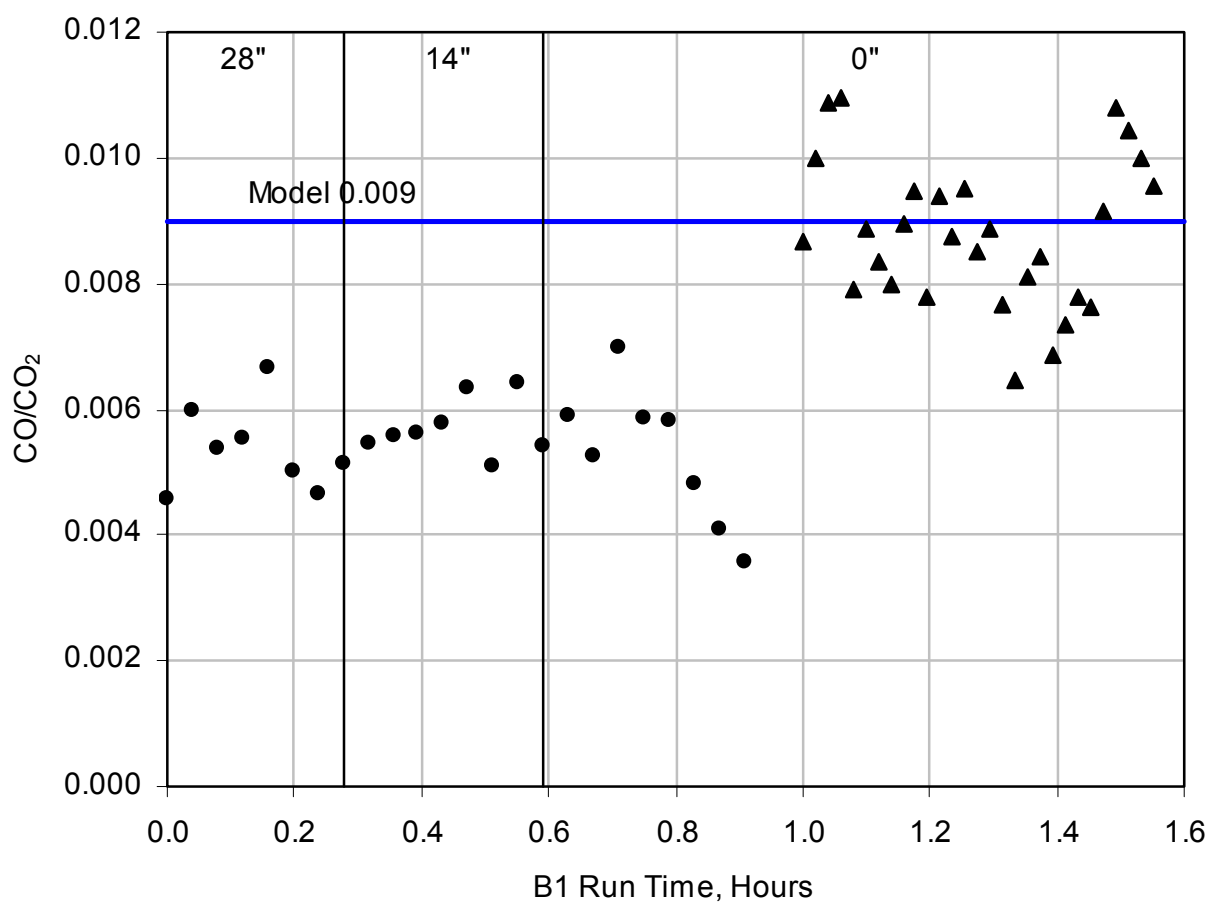

Figure 2-21. Model prediction of carbon distribution production compared to DM1200 experimental data with $B 1$ feed

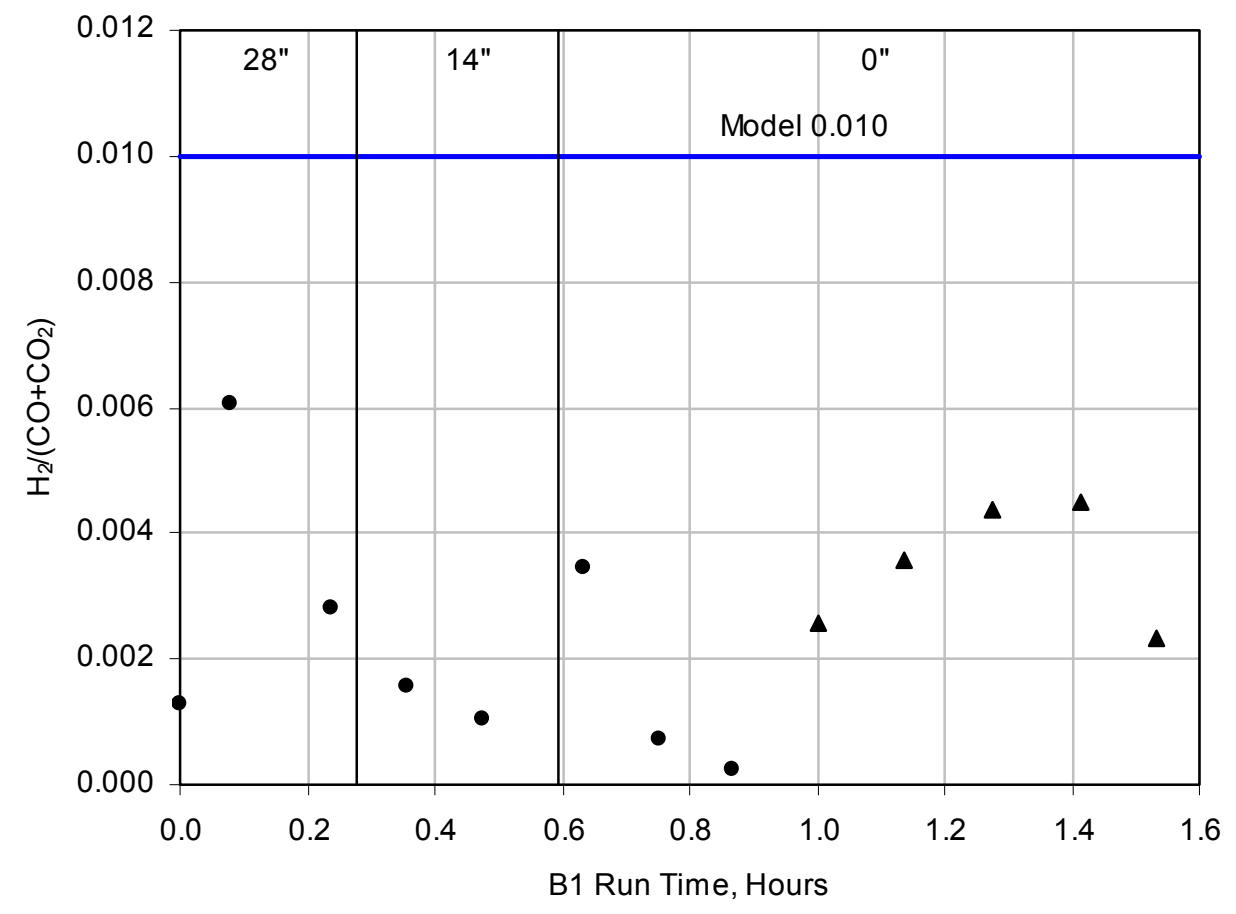

Figure 2-22. Model prediction of hydrogen production compared to DM1200 experimental data with $B 1$ feed 
WSRC-TR-2003-00285, REVISION 0

SRT-RPP-2003-00130, REVISION 0

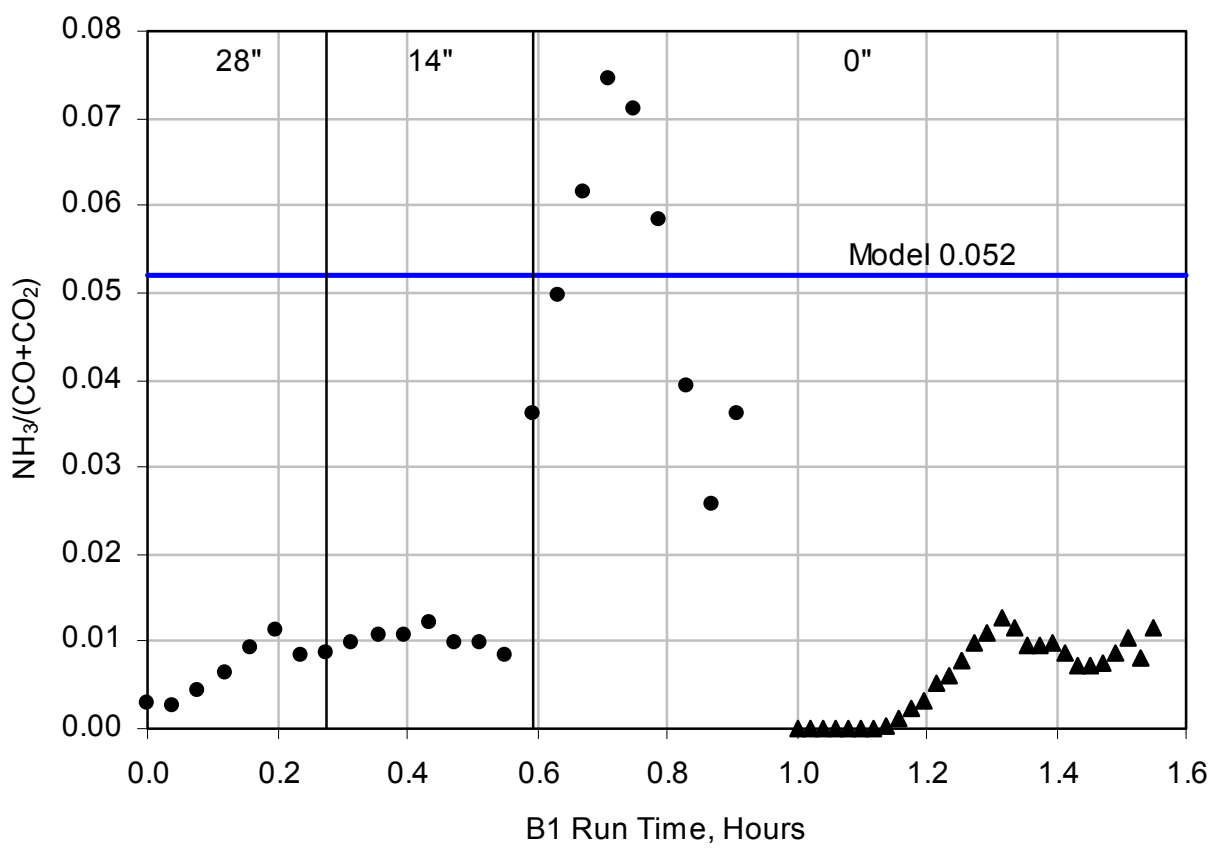

Figure 2-23. Model prediction of ammonia production compared to DM1200 experimental data with $B 1$ feed

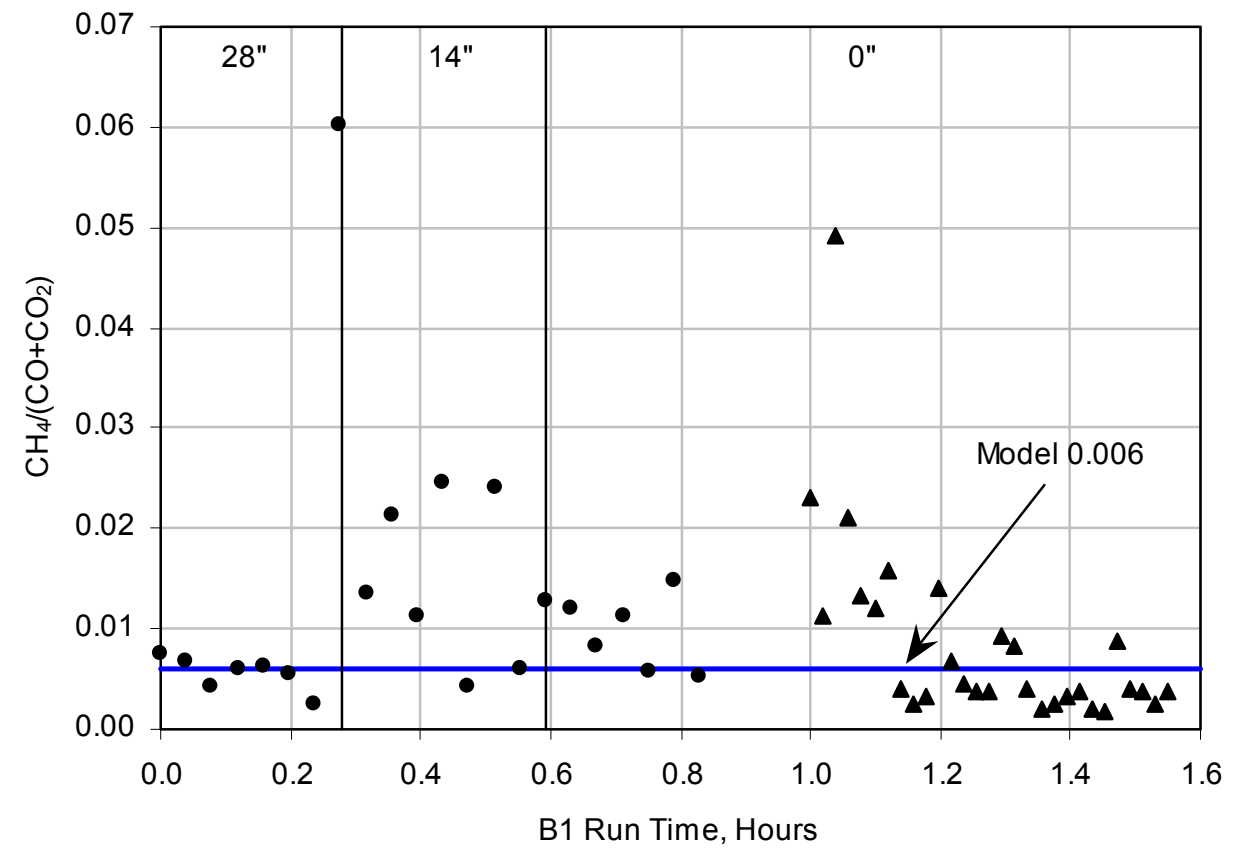

Figure 2-24. Model prediction of methane production compared to DM1200 experimental data with $B 1$ feed 


\section{WSRC-TR-2003-00285, REVISION 0 SRT-RPP-2003-00130, REVISION 0}

\subsection{MELTER PLENUM COMBUSTION MODEL}

The flammable offgas components identified during the pilot melter runs at VSL included $\mathrm{CO}, \mathrm{H}_{2}$, and $\mathrm{NH}_{3}$ [Matlack, 2002a-2003d]. During some of those VSL melter runs, the total hydrocarbon (THC) was also measured in terms of propane equivalents at concentrations comparable to that of $\mathrm{CO}$; however, no attempt was made to identify major constituent $\mathrm{HC}$ species. As a result, the cold cap model was set up to produce methane as a representative $\mathrm{HC}$ species, and its predicted concentration for the Envelope A1 feed was only $\sim 25 \%$ of the peak THC data multiplied by a factor of 3 , which is the propane-to-methane carbon ratio.

The reason for this non-bounding THC prediction is that it was not feasible to devise the model such that its predictions would bound all measured flammable gas concentrations simultaneously, so bounding the $\mathrm{CO}$ and $\mathrm{H}_{2}$ data was given a higher priority. Nevertheless, the approach of converting the measured THC data into methane equivalents and using them as a benchmark for the cold cap model should help recover some of the potential loss in conservatism due to non-bounding THC predictions, since the LFL for methane is $25 \%$ lower than that of propane on an equal carbon basis (see the sample calculations in Appendix D). As an additional measure of ensuring conservatism, it was also decided not to allow any combustion of methane in the vapor space, thereby rendering the resulting offgas exiting the melter even more flammable.

As described earlier in this report, one of the few shortcomings of the cold cap model was the fact that one of the most abundant components of calcine gases, $\mathrm{N}_{2}$, was not allowed to form at all, since its formation is so favored thermodynamically that the model would not predict formation of any nitrogen oxide species contrary to the clear trend shown by the data; up to $50 \%$ of nitrate/nitrite fed was converted into nitrogen oxides at the nominal sugar level [Matlack, 2003c]. It was, therefore, necessary to adjust the $\mathrm{NO}_{\mathrm{x}}$ partitioning predicted by the cold cap model in order to match the observed trend and produce $\mathrm{N}_{2}$ at the same time, and it was this adjusted calcine gas composition that was used as the incoming fuel to the combustion model.

The concentration of $\mathrm{NH}_{3}$ predicted by the cold cap model was not affected by this $\mathrm{NO}_{\mathrm{x}}-\mathrm{N}_{2}$ adjustment process and was taken as the input to the combustion model without any adjustment. Instead, the overall combustion efficiency of $\mathrm{NH}_{3}$ in the melter plenum was later adjusted to match its measured concentration downstream of the melter and the measured $\mathrm{pH}$ 's of both SBS and Wet Electrostatic Precipitator (WESP) condensates. However, since nearly $100 \%$ of unburned $\mathrm{NH}_{3}$ will get scrubbed out in the SBS, it will have no impact on the offgas flammability assessment. So, the purpose of these adjustments was to account for the slight reduction in dilution due to losses of $\mathrm{NH}_{3}$ and $\mathrm{NO}_{\mathrm{x}}$ in the SBS \& WESP via absorption and the resulting increase in the flammable gas concentration. 
The predicted concentrations of $\mathrm{CO}$ and $\mathrm{H}_{2}$ were shown earlier to bound the DM10 data well and thus required no further adjustments [Matlack, 2003d]. Therefore, the primary focus of the combustion model was to describe time-dependent fates of these two flammable species in the melter plenum using the CHEMKIN software. For the purpose of model validation, however, it was necessary to describe their fates throughout the offgas system up to the WESP, since nearly all available $\mathrm{H}_{2}$ data were taken at the WESP exit during the VSL runs. The steady state modeling of both offgas and condensate chemistry beyond the melter was done by developing a comprehensive mass balance spreadsheet using Microsoft ${ }^{\circledR}$ EXCEL.

\subsubsection{Development of LAW Combustion Model}

The plenum combustion model consists of two essential components; combustion kinetics of flammable gases and a reactor model representing the melter plenum. Ideally, a detailed CFD model based on elementary kinetic schemes would provide a complete description of both velocity and temperature profiles in the melter plenum from which the overall combustion efficiencies can be determined accurately. However, such a detailed modeling approach is presently quite difficult and not practical partly due to the fact that the cold cap surface is highly heterogeneous and even difficult to define physically. In addition, validation of first-principle models and subsequent scale up would be a real challenge, because it is inherently difficult to measure the true cold cap offgas compositions in the first place, which constitute the vital input data for such models.

So, a global kinetic modeling approach was chosen for this work. The idea of global kinetic modeling is to lump all the effects of complex heat transfer and fluid mixing in the melter plenum into the global kinetic parameters and optimize them using experimental data. Since both $\mathrm{CO}$ and $\mathrm{H}_{2}$ also form the major flammable components of the DWPF melter exhaust, it was decided to use the existing DWPF model of $\mathrm{CO}$ and $\mathrm{H}_{2}$ combustion as a starting point for the development of LAW melter model. Since the kinetics of $\mathrm{CO}$ and $\mathrm{H}_{2}$ combustion are independent of the feed chemistry, the extent of necessary adjustments would be determined largely by how different the fluid mixing and heat transfer characteristics of the two melters are. The DWPF global kinetic parameters were derived from the data collected during the Scale Glass Melter Run \#9 (SGM-9), during which all variables known to affect offgas flammability such as air purge, plenum temperature and TOC were varied, and the resulting offgas compositions downstream of the venturi scrubber were monitored using the LFL monitors in addition to the standard gas analyzers following the EPA protocols [Choi, 1988]. 


\subsubsection{DWPF Combustion Model}

Some of the key bases of the DWPF combustion models include:

1. Oxygen is assumed to be present in sufficient excess of the stoichiometric amount required to burn all flammable gases entering the plenum reactor.

2. The combustion reactions are first-order:

\section{Equation 1}

Equation 2

$$
-r_{C O}=k_{C O} C_{C O}
$$

$$
-r_{H_{2}}=k_{H_{2}} C_{H_{2}}
$$

where:

$\mathrm{r}=$ the reaction rates in gmoles $/ \mathrm{cm}^{3} / \mathrm{sec}$

$\mathrm{k}=$ the first-order rate constants in $1 / \mathrm{sec}$

$\mathrm{C}=$ the concentrations in gmoles $/ \mathrm{cm}^{3}$

3. The melter plenum is a perfectly stirred reactor (PSR), and the relevant performance equations are:

Equation 3

$$
k_{C O}=\frac{v_{i} C_{C O, i} X_{C O}}{v_{o} C_{C O} \tau}
$$

\section{Equation 4}

$$
k_{H_{2}}=\frac{v_{i} C_{H_{2}, i} X_{H_{2}}}{v_{o} C_{H_{2}} \tau}
$$

where:

$\mathrm{v}=$ the volumetric flow rates in $\mathrm{cm}^{3} / \mathrm{sec}$

$\mathrm{X}=$ the fractional conversions

$\tau=$ the gas residence time in seconds

subscripts $i$ and $o=$ the inlet and outlet, respectively

4. Since the inlet concentrations of both $\mathrm{CO}$ and $\mathrm{H}_{2}$ are relatively low, e.g., on the order of $0.1 \mathrm{~mole} \%$ for the baseline feed with $1 \mathrm{X}$ nominal sugar, the density in the melter plenum is assumed to be constant. So,
Equation 5

$$
C_{C O}=C_{C O, i}\left(1-X_{C O}\right)
$$


Equation 6

$$
C_{H_{2}}=C_{H_{2}, i}\left(1-X_{H_{2}}\right)
$$

At constant density, $v_{i}=v_{o}$. So, substitution of Equation 5 into Equation 3 and rearrangement yields the fractional conversion of $\mathrm{CO}$ as:

Equation $7 \quad X_{C O}=\frac{k_{C O} \tau}{1+k_{C O} \tau}$

Likewise, substitution of Equation 6 into Equation 4 and rearrangement yields the fractional conversion of $\mathrm{H}_{2}$ as:

Equation 8

$$
X_{H_{2}}=\frac{k_{H_{2}} \tau}{1+k_{H_{2}} \tau}
$$

5. The first-order rate constants, $k_{\mathrm{H} 2}$ and $k_{\mathrm{CO}}$, are further expressed in the Arrhenius form:

Equation 9

$$
k_{C O}=k_{o, C O} \exp \left(\frac{-E_{a, C O}}{R T}\right)
$$

Equation 10

$$
k_{H_{2}}=k_{o, H_{2}} \exp \left(\frac{-E_{a, H_{2}}}{R T}\right)
$$

where:

$\mathrm{k}_{\mathrm{o}}=$ the preexponential factors in $1 / \mathrm{sec}$

$\mathrm{E}_{\mathrm{a}}=$ the activation energies in cal/gmole

$\mathrm{R}=$ the universal gas constant in $\mathrm{cal} / \mathrm{gmole} / \mathrm{K}$

$\mathrm{T}=$ the mean gas temperature in degrees Kelvin

The values of $k_{o}$ 's and $E_{a}$ 's regressed using the SGM-9 data are shown in Table 2-2. These global kinetic parameters have been validated against the offgas data taken during DWPF pilot melter runs of different scales and subsequently used in the safety basis calculations [Choi, 2000]. Figure 2-25 and Figure 2-26 clearly show how well the global kinetic model bounds both $\mathrm{CO}$ and $\mathrm{H}_{2}$ data taken during the $1 / 80^{\text {th }}$ scale $774-\mathrm{A}$ melter run. 
The question of how much excess combustion air can be regarded as being sufficient in the Model Basis \#1 above is somewhat arbitrary. In typical industrial applications, 20\% excess air is used to compensate for the nonideal gas mixing in the combustion chamber. However, DWPF has chosen $50 \%$ excess air as their safety basis due to the fact that being an efficient combustor was not one of the original design goals of the DWPF melter. In this work, both 20 and $50 \%$ excess air requirements were considered in order to scope out the impact of air purge, including melter air inleakage, on offgas flammability.

Table 2-2. Global First-Order Kinetic Parameters for DWPF Melter Plenum Combustion Model (Derived from SGM-9 Data)

\begin{tabular}{|l|c|c|c|}
\hline & $\begin{array}{c}\mathbf{k}_{\mathbf{0}} \\
(\mathbf{1} / \mathbf{s e c})\end{array}$ & $\begin{array}{c}\mathbf{E}_{\mathbf{a}} \\
(\mathbf{c a l} / \mathbf{g m o l e})\end{array}$ & $\mathbf{R}^{\mathbf{2}}$ \\
\hline $\mathrm{CO}$ & 1,759 & 12,329 & 0.845 \\
\hline $\mathrm{H}_{2}$ & $2.795 \mathrm{E} 7$ & 21,633 & 0.999 \\
\hline
\end{tabular}

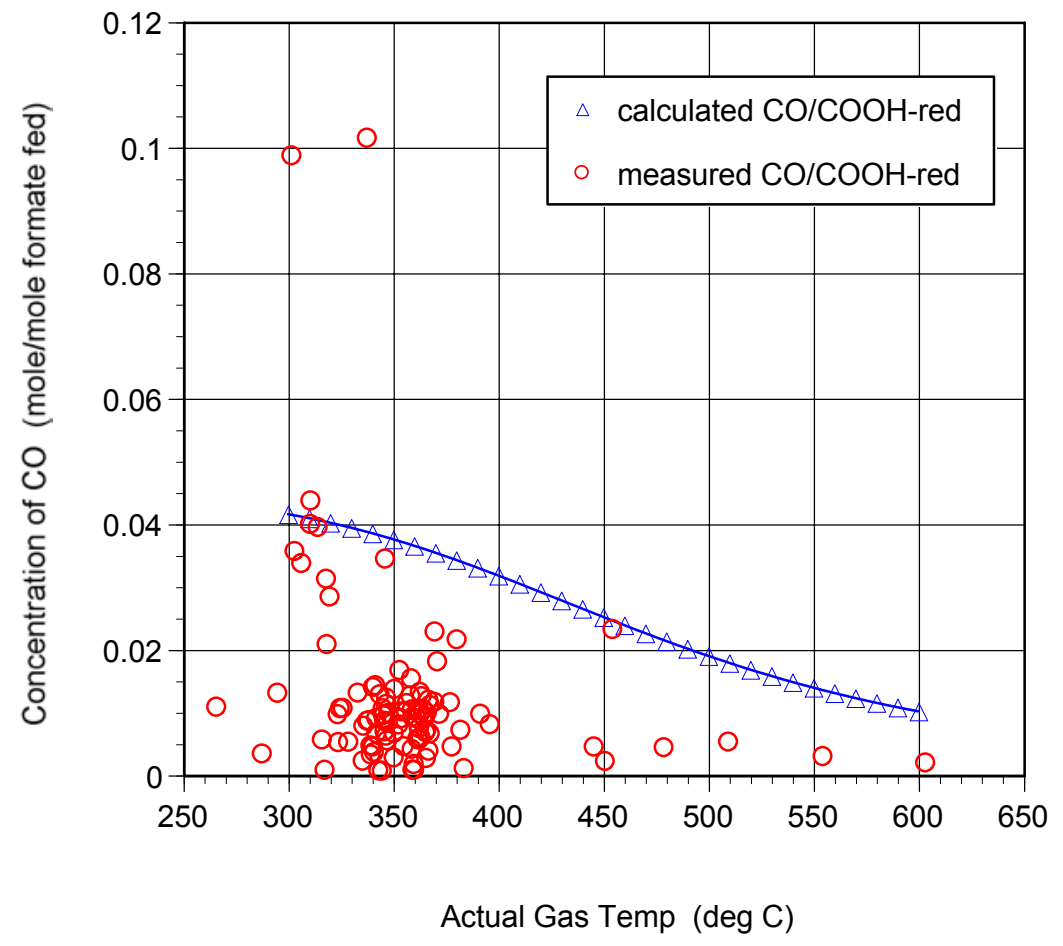

Figure 2-25. Calculated Concentrations of CO Using DWPF Combustion Model vs. Measured Data During 774-A Melter Run 
WSRC-TR-2003-00285, REVISION 0

SRT-RPP-2003-00130, REVISION 0

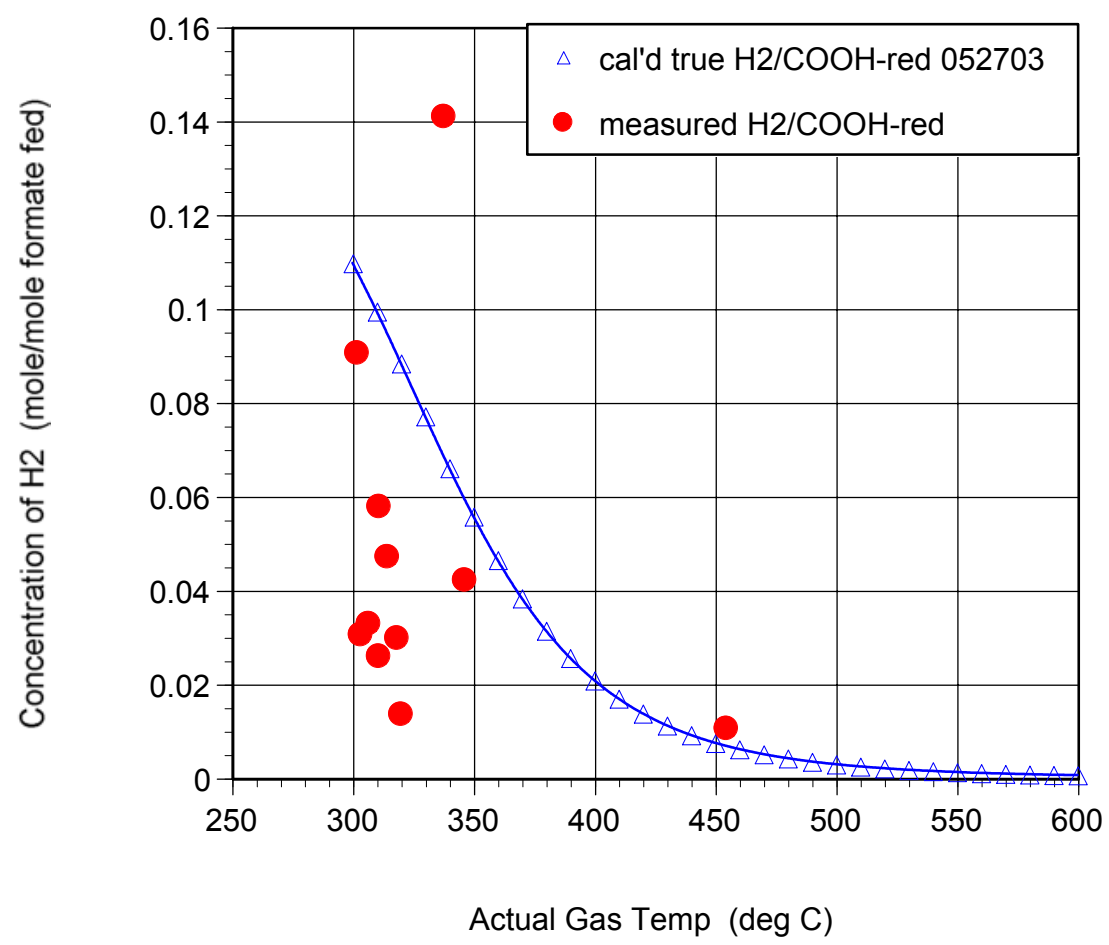

Figure 2-26. Calculated Concentrations of $\mathrm{H}_{2}$ Using DWPF Combustion Model vs. Measured Data During 774-A Melter Run

\subsubsection{Bases of LAW Melter Combustion Model}

As stated earlier, the global kinetic parameters for the LAW melter combustion model were derived by modifying those shown in Table 2-2, and the offgas data taken during the DM-1200 run with the Envelope A1 simulant was selected as the baseline data for doing so [Matlack, 2002b]. The entire DM1200 A1 run consisted of 3 steady state feeding periods, and offgas data were reported as the average values during each steady state period. After carefully examining all relevant data including plenum temperature, offgas and particulate analysis, the average offgas data reported for the second steady state feeding period was judged to be most representative of a steady state operation. The selection of Envelope A1 simulant as the baseline feed was based on the fact that although the reductant ratio, defined as the molar ratio of TOC to nitrate/nitrite in feed, was set at 0.5 for the waste simulants used in all VSL runs, it ended up containing the most sugar per liter of the final feed, and the overbatching of sugar was one of the primary safety concerns to be addressed in this work.

Two variables are essential to the success of combustion modeling, but their values cannot be measured directly. The first is the melter air inleakage which varies with changing melter vacuum relative to that of the melt cell and therefore cannot be regarded as a controlled air purge for combustion and/or dilution. The second is the mean gas temperature of the melter plenum. The plenum temperatures are typically measured in a suspended thermowell, and the readings indicated by the thermocouple inside a thermowell would unavoidably include the effect of thermal radiation impinging on the thermowell. 
As a result, indicated readings tend to be somewhat higher than the corresponding true gas temperatures. These indicated readings also tend to vary depending on the location of measurement in the plenum, and it is the mean gas temperature that is used in the calculation of combustion kinetics. In this work, both melter air inleakage and plenum gas temperature were estimated simultaneously by solving mass and energy balance equations in and around the melter.

Furthermore, since the concentration of $\mathrm{H}_{2}$ was measured only at the WESP exit during the DM1200 A1 run, it was necessary to develop a steady state mass balance model describing both offgas and condensate chemistry beyond the melter at least up to the WESP, and this was done using a spreadsheet. Some of the key bases of the LAW melter combustion and offgas spreadsheet models include:

1. The baseline feed was Envelope A1 (Tank AN-105) simulant.

2. The combustion of $\mathrm{CO}, \mathrm{H} 2$ and $\mathrm{NH} 3$ was not considered beyond the melter.

Note: The reaction rates based on the Arrhenius rate expressions given by Equation 9 and Equation 10 will never go to zero, no matter how low the temperature becomes. At temperatures below $\sim 250{ }^{\circ} \mathrm{C}$, however, the reaction rates slow down so much that they become practically insignificant. The LAW melter exhaust is cooled to near $300{ }^{\circ} \mathrm{C}$ in the film cooler. At this temperature, the reaction rate $(k)$ can be still appreciably above zero, but the residence time $(\tau)$ is too short to achieve any significant overall conversion given by Equation 7 and Equation 8.

3. The average offgas data taken at the WESP exit during DM1200 A1 run steady state feeding period \#2 (SS2) provided the target values for model adjustment.

4. The Method 29 Melter-Out Sample \#3 (Teflon) taken at the $74^{\text {th }}$ hour of DM1200 A1 run provided the key data for determining both melter air inleakage and true plenum gas temperature.

5. The average $\mathrm{pH}$ of SBS condensate during SS2 was assumed to be neutral or slightly acidic, while that of WESP condensate was assumed to be near zero.

6. The following reactions were assumed to occur at the SBS and WESP:

\section{Reaction i}

Reaction ii

Reaction iii

$$
\mathrm{NH}_{3}(a q)+\mathrm{H}_{2} \mathrm{O}=\mathrm{NH}_{4}^{+}+\mathrm{OH}^{-}
$$$$
2 \mathrm{NO}+\mathrm{O}_{2}=2 \mathrm{NO}_{2}
$$

$$
2 \mathrm{NO}_{2}+\mathrm{H}_{2} \mathrm{O}=2 \mathrm{H}^{+}+\mathrm{NO}_{3}^{-}+\mathrm{NO}_{2}^{-}
$$


7. The following reactions was assumed to occur in the melter plenum for $\mathrm{NH}_{3}$ :

Reaction iv $2 \mathrm{NH}_{3}+2.5 \mathrm{O}_{2}=2 \mathrm{NO}+3 \mathrm{H}_{2} \mathrm{O}$

8. Air inleakage was added to the SBS/WESP to match the offgas flow data taken at the WESP exit, and no gas holdup was assumed in the SBS.

Reaction (i) was set to go to completion. The overall conversions of Reactions (ii) and (iii) were set simultaneously with that of Reaction (iv) in order to match both $N O_{x}$ partitioning and condensate $\mathrm{pH}$ data.

In Table 2-3, the calcine gas composition predicted by the cold cap model is compared against the adjusted composition and the VSL data. Clearly, the adjusted composition shows considerably less $\mathrm{NO}$ and $\mathrm{N} 2 \mathrm{O}$ as a result of adding $\mathrm{N} 2$. It is also noted that the percent conversion of nitrate/nitrite in the feed into NOx was reduced from the high $87 \%$ to $35 \%$ and, after allowing absorption of NO/NO2 per Reactions (ii) and (iii), the latter conversion value was found to closely match the NOx data taken downstream of the SBS, as shown in the next section. Although DM100 A3 data showed 51\% conversion of nitrate/ nitrite fed into NOx, the conversion appears to depend on the overall feed chemistry. For example, the measured conversion during DM1200 C1 Run was $~ 40 \%$, which is more in line with the estimated 35\% for the Envelope A1 feed [Matlack, 2002a].

Some of the key process data used in the development of LAW melter combustion model are included in Table 2-4. These data were taken directly from the DM1200 A1 Run report [Matlack, 2002b]. 
WSRC-TR-2003-00285, REVISION 0

SRT-RPP-2003-00130, REVISION 0

Table 2-3. Predicted vs. Adjusted Envelope A1 Calcine Gas Compositions

\begin{tabular}{|c|c|c|c|c|}
\hline & $\begin{array}{r}\text { Cold Cap Model } \\
\text { Output }\end{array}$ & $\begin{array}{l}\text { Adjusted Input to } \\
\text { Combustion Model }\end{array}$ & $\begin{array}{r}\text { DM10 A1 Data } \\
\text { [Matlack, 2003d] }\end{array}$ & Comment on Data \\
\hline & (mole fraction) & (mole fraction) & & \\
\hline calcine $\mathrm{H} 2 \mathrm{O}$ & 0.67633 & 0.70375 & & \\
\hline $\mathrm{CO}$ & 0.00416 & 0.00373 & & \\
\hline $\mathrm{CO}_{2}$ & 0.14348 & 0.12862 & & \\
\hline $\mathrm{H}_{2}$ & 0.00468 & 0.00357 & & \\
\hline NO & 0.09296 & 0.03930 & & \\
\hline $\mathrm{N}_{2} \mathrm{O}$ & 0.03439 & 0.00531 & & \\
\hline $\mathrm{NO}_{2}$ & 0.00063 & 0.00850 & & \\
\hline $\mathrm{NH}_{3}$ & 0.02620 & 0.02351 & & \\
\hline $\mathrm{O}_{2}$ & 0.01175 & 0.03746 & & \\
\hline $\mathrm{N}_{2}$ & 0.00000 & 0.04366 & & \\
\hline $\mathrm{CH}_{4}$ & 0.00272 & 0.00260 & & \\
\hline Total & 0.99730 & 1.00000 & & \\
\hline $\mathrm{CO} / \mathrm{CO}_{2}$ & 0.029 & 0.029 & 0.031 & peak DM10 A1 \\
\hline $\mathrm{H}_{2} /\left(\mathrm{CO}+\mathrm{CO}_{2}\right)$ & 0.032 & 0.027 & 0.027 & $"$ \\
\hline $\mathrm{THC} /\left(\mathrm{CO}+\mathrm{CO}_{2}\right)$ & 0.018 & 0.020 & 0.072 & $"$ \\
\hline $\mathrm{NH}_{3} / \mathrm{NO}_{\mathrm{x}}$ & 0.161 & 0.402 & 0.680 & $"$ \\
\hline $\mathrm{NO}_{x} /\left(\mathrm{NO}_{3}+\mathrm{NO}_{2}\right)$ & 0.87 & 0.35 & 0.51 & DM100 A3 data \\
\hline $\mathrm{NO} / \mathrm{NO}_{\mathrm{x}}$ & 0.726 & 0.74 & 0.78 & average DM10 A1 \\
\hline $\mathrm{N}_{2} \mathrm{O} / \mathrm{NO}_{\mathrm{x}}$ & 0.269 & 0.16 & 0.14 & $"$ \\
\hline $\mathrm{NO}_{2} / \mathrm{NO}_{\mathrm{x}}$ & 0.005 & 0.10 & 0.08 & $"$ \\
\hline
\end{tabular}


Table 2-4. Process Data Input to LAW Model for DM1200 A1 Run

\begin{tabular}{|c|c|c|}
\hline & & Comments \\
\hline sugar addition ( $\mathrm{X}$ A1 Baseline) & 1 & \\
\hline feed rate less sugar $(\mathrm{kg} / \mathrm{hr})$ & 192 & SS2 average \\
\hline glass production rate $\left(\mathrm{kg} / \mathrm{m}^{2} /\right.$ day $)$ & 1,980 & based on feed data \\
\hline total fixed melter air purge (scfm) & 0.6637 & $100 \%$ via air bubblers \\
\hline film cooler air purge (cfm) & 70 & SS2 average \\
\hline film cooler air temperature $\left({ }^{\circ} \mathrm{C}\right)$ & 99 & " \\
\hline off-gas temp @ film cooler exit $\left({ }^{\circ} \mathrm{C}\right)$ & 300 & taken at $74^{\text {th }}$ hour \\
\hline pressure control air (scfm) & 32 & fixed during enitre $A 1$ Run \\
\hline off-gas flow in transition pipe (dscfm) & 175.35 & Method 29 taken at $74^{\text {th }}$ hour \\
\hline (\% moisture) & $29.13 \%$ & $"$ \\
\hline SBS exit temperature $\left({ }^{\circ} \mathrm{C}\right)$ & 40 & taken at $74^{\text {th }}$ hour \\
\hline off-gas flow @ WESP exit (scfm) & 217 & " \\
\hline temperature @ WESP exit $\left({ }^{\circ} \mathrm{C}\right)$ & 44 & $"$ \\
\hline H2O spray to WESP (gal/hr) & 1.51 & SS2 average \\
\hline
\end{tabular}

\subsubsection{Results of LAW Melter Combustion Model}

Both LAW melter combustion model and offgas mass balance spreadsheet were run by adjusting various parameters shown in lightly shaded areas of Table 2-5, until a satisfactory overall match was found between calculated and measured offgas data. The model was run first by using the DWPF global kinetic parameters given in Table 2-2, and it is shown to over predict the overall combustion efficiency of $\mathrm{H}_{2}$ in the melter, resulting in a concentration of $\mathrm{H}_{2}$ at the WESP exit that is less than $50 \%$ of the measured average. The predicted molar ratio of $\mathrm{CO}$ to $\mathrm{CO}_{2}$ at the WESP exit was also lower than the measured average by $\sim 20 \%$, indicating that the DWPF global kinetic parameters over predicted the combustion efficiency of CO.

Reduced combustion efficiencies of $\mathrm{H}_{2}$ and CO during DM1200 A1 run may be explained in two ways. First, the empirical fitting of the DWPF global kinetic parameters was done using the data containing higher concentrations of $\mathrm{CO}$ and $\mathrm{H}_{2}$ than those measured during the VSL runs. For example, the molar ratio of $\mathrm{CO}$ to $\mathrm{CO}_{2}$ predicted for the SGM-9 feed was in the range of 0.12 [Choi, 2000], which is about 4 times higher than those shown in Table 2-3. Likewise, the molar ratio of $\mathrm{H}_{2}$ to $\mathrm{CO}+\mathrm{CO}_{2}$ was also much higher, perhaps by more than a factor of 4. Higher concentrations of flammable gases in the SGM-9 offgas was due to more reducing feed and less dilution air used during SGM-9 run than those used in all VSL runs. 
WSRC-TR-2003-00285, REVISION 0

SRT-RPP-2003-00130, REVISION 0

Table 2-5. LAW Model Results vs. Measured Data During DM1200 A1 Run

\begin{tabular}{|c|c|c|c|}
\hline & LAW Model_1 & LAW Model_2 & DM1200 A1 Data \\
\hline global kinetic parameters & DWPF & Modified & \\
\hline $\mathrm{E}_{\mathrm{a}, \mathrm{co}}(\mathrm{cal} / \mathrm{gmole})$ & 12,329 & 13,529 & \\
\hline $\mathrm{E}_{\mathrm{a}, \mathrm{H} 2} \quad(\mathrm{cal} / \mathrm{gmole})$ & 21,633 & 22,853 & \\
\hline conversion of $\mathrm{NH}_{3}$ via $\mathrm{Rxn}$ (iv) & $72.5 \%$ & $72.5 \%$ & \\
\hline \multicolumn{4}{|l|}{ calculated results } \\
\hline melter air inleakage (scfm) & 78.35 & 78.35 & \\
\hline plenum gas temperature $\left({ }^{\circ} \mathrm{C}\right)$ & 365.19 & 365.19 & 400 \\
\hline measured - calculated temp $\left({ }^{\circ} \mathrm{C}\right)$ & 34.81 & 34.81 & \\
\hline residence time in plenum (sec) & 7.95 & 7.95 & \\
\hline off-gas temp inc. control air $\left({ }^{\circ} \mathrm{C}\right)$ & 267.00 & 267.00 & \\
\hline off-gas temp @ SBS inlet $\left({ }^{\circ} \mathrm{C}\right)$ & & & 250 \\
\hline SS heat input into plenum (cal/sec) & 6766 & 6766 & 6875 \\
\hline $\mathrm{T}$ drop across transit'n pipe $\left({ }^{\circ} \mathrm{C}\right)$ & 17.00 & 17.00 & \\
\hline \multicolumn{4}{|l|}{ SBS chemistry adjustment } \\
\hline conversion of Reaction (ii) & $37.0 \%$ & $37.0 \%$ & \\
\hline conversion of Reaction (iii) & $10.0 \%$ & $10.0 \%$ & \\
\hline \multicolumn{4}{|l|}{ off-gas composition @ SBS exit } \\
\hline $\mathrm{H}_{2} \mathrm{O}(\%)$ & $7.3 \%$ & $7.3 \%$ & $8.6 \%$ \\
\hline $\mathrm{CO}_{2}(\mathrm{ppmv})$ & 19017 & 18899 & 29932 \\
\hline $\mathrm{CO}$ (ppmv) & 298 & 413 & 456 \\
\hline $\mathrm{H}_{2}$ (ppmv) & 54 & 121 & $\mathrm{n} / \mathrm{a}$ \\
\hline NO (ppmv) & 5212 & 5211 & 5053 \\
\hline $\mathrm{N}_{2} \mathrm{O}(\mathrm{ppmv})$ & 780 & 780 & 908 \\
\hline $\mathrm{NO}_{2}$ (ppmv) & 3878 & 3877 & 3560 \\
\hline $\mathrm{NH}_{3}$ (ppmv) & 0 & 0 & 8 \\
\hline $\mathrm{CO}+\mathrm{CO}_{2}(\mathrm{ppmv})$ & 19315 & 19311 & 30387 \\
\hline $\mathrm{CO} / \mathrm{CO} 2$ & 0.016 & 0.022 & 0.015 \\
\hline \multicolumn{4}{|l|}{ WESP chemistry adjustment } \\
\hline conversion of Reaction (ii) & $30.0 \%$ & $30.0 \%$ & \\
\hline conversion of Reaction (iii) & $5.0 \%$ & $5.0 \%$ & \\
\hline airleak into SBS/WESP (scfm) & 10.2 & 10.2 & \\
\hline \multicolumn{4}{|l|}{ off-gas composition @ WESP exit } \\
\hline $\mathrm{H}_{2} \mathrm{O}(\%)$ & $8.3 \%$ & $8.3 \%$ & $8.7 \%$ \\
\hline $\mathrm{CO}_{2}(\mathrm{ppmv})$ & 17777 & 17667 & 24321 \\
\hline $\mathrm{CO}$ (ppmv) & 278 & 386 & 482 \\
\hline $\mathrm{H}_{2}$ (ppmv) & 50[ & 113 & 111 \\
\hline NO (ppmv) & 3472 & 3471 & 3694 \\
\hline $\mathrm{N}_{2} \mathrm{O}(\mathrm{ppmv})$ & 729 & 729 & 684 \\
\hline $\mathrm{NO}_{2}(\mathrm{ppmv})$ & 4858 & 4858 & 5792 \\
\hline $\mathrm{NH}_{3}$ (ppmv) & 0 & 0 & 0 \\
\hline $\mathrm{CO}+\mathrm{CO}_{2}(\mathrm{ppmv})$ & 18055 & 18052 & 24803 \\
\hline $\mathrm{CO} / \mathrm{CO} 2$ & 0.01566[ & 0.02185 & 0.01982 \\
\hline
\end{tabular}




\section{WSRC-TR-2003-00285, REVISION 0 SRT-RPP-2003-00130, REVISION 0}

Over-prediction of VSL data by the DWPF global kinetic parameters could also be attributed to the differences in two melter designs. The global kinetic parameters implicitly include non-kinetic effects such as fluid mixing and heat transfer in the plenum, and these transport effects in the DM1200 melter may not have been as efficient as in the DWPF melter. One design feature that could impact the transport effects is the overall plenum geometry; the DWPF melter plenum is cylindrical, while that of the DM1200 melter is rectangular, and the mixing efficiency of the latter geometry is known to be inferior to that of the former.

One way to account for this inferior mixing effect is to increase the activation energies, while leaving the pre-exponential factors untouched. The results of a second LAW model run with the modified activation energies are also shown in Table 2-5; the predicted $\mathrm{H}_{2}$ and $\mathrm{CO} / \mathrm{CO}_{2}$ molar ratio are seen to be in excellent agreement with data. The revised global kinetic parameters used in all subsequent LAW model runs are summarized in Table 2-6, which shows that the necessary adjustments made on the activation energies over the corresponding DWPF values were relatively small; $9.7 \%$ and $5.6 \%$ increase for $\mathrm{CO}$ and $\mathrm{H}_{2}$, respectively. Attempts were also made to adjust the pre-exponential factors instead, but the outcome was not nearly as good as adjusting the activation energies, and this result is consistent with the fact that these global kinetic parameters are not intrinsic.

Table 2-6. Global First-Order Kinetic Parameters for LAW Melter Plenum Combustion Model

\begin{tabular}{|l|c|c|c|}
\hline & $\begin{array}{c}\mathbf{k}_{\mathbf{o}} \\
(\mathbf{1} / \mathbf{s e c})\end{array}$ & $\begin{array}{c}\mathbf{E}_{\mathbf{a}} \\
(\mathbf{c a l} / \mathbf{g m o l e})\end{array}$ & $\begin{array}{c}\text { \% Increase } \\
\text { Over DWPF }\end{array}$ \\
\hline $\mathbf{C O}$ & 1,759 & 13,529 & 9.7 \\
\hline $\mathbf{H}_{\mathbf{2}}$ & $2.795 \mathrm{E} 7$ & 22,853 & 5.6 \\
\hline
\end{tabular}

As described earlier, two variables most affecting the offgas flammability, besides the global kinetic parameters, are the melter air inleakage (by way of gas residence time and dilution) and actual gas temperature in the plenum (by way of kinetics mostly and, to a lesser extent, gas residence time). Table 2-5 shows the calculated values of these variables. The DM1200 melter air inleakage was estimated to be about $80 \mathrm{scfm}$, which is more than 3 times the design basis air inleakage rate for the DWPF melter. Therefore, melter air inleakage will play a much bigger role in the LAW offgas flammability assessment than in DWPF.

The true plenum gas temperature was estimated to be $35^{\circ} \mathrm{C}$ lower than the measured value in a thermowell suspended 17" below the ceiling. As a comparison, the estimated temperature differences for the DWPF melter plenum are much larger, typically in the range of 100 to $150{ }^{\circ} \mathrm{C}$ during the feeding. This discrepancy can also be attributed to one important design difference; all melters used in the VSL runs did not have the auxiliary dome heaters, while the DWPF melter has 4 pairs of Inconel heater tubes suspended horizontally in the plenum. During normal feeding operation, more power is sent to these dome heaters than to the electrodes. As a result, the amount of radiant heat incident on the plenum thermowell is quite large, resulting in much higher indicated temperatures than in those with no dome heaters. 
During the process of adjusting the global kinetic parameters, the predicted concentration of $\mathrm{CO}$ was compared against the data in terms of the molar ratio of $\mathrm{CO} / \mathrm{CO}_{2}$ rather than its absolute concentration. This was because despite repeated attempts to improve the overall carbon balance, the discrepancies between the calculated and measured molar flows of CO and $\mathrm{CO}_{2}$ combined were large, $37 \%$ and $27 \%$ for the SBS and WESP, respectively. One reason for this large carbon imbalance could be due to the inherent difficulty associated with comparing model predictions based on the data taken at the $74^{\text {th }}$ hour against the reported average values over the entire SS2 period that lasted over 70 hours.

On the other hand, the offgas flow measured at the WESP exit at the $74^{\text {th }}$ hour of the DM1200 A1 run was only 5\% higher than the calculated value, and this small difference was subsequently attributed to the air inleakage in both the SBS and WESP combined. The resulting air inleakage was estimated to be $10.2 \mathrm{scfm}$, which is less than $5 \%$ of the measured offgas flow. Once a perfect agreement was achieved between measured and calculated offgas flows by adding this small air inleakage, the predicted concentrations of the remaining species, including $\mathrm{H}_{2} \mathrm{O}, \mathrm{H}_{2}$ and $\mathrm{NO}_{\mathrm{x}}$, were compared directly to their measured counterparts, rather than their ratios to, for example, the combined concentrations of $\mathrm{CO}$ and $\mathrm{CO}_{2}$. For the two flammable species $\mathrm{CO}$ and $\mathrm{H}_{2}$, predicted values are seen to be slightly higher than those measured.

Not shown in Table 2-5are the calculated pH values of both SBS and WESP condensates; they were 6.6 and 0.0, respectively, and both values were well within the ranges of measured data. It was stated earlier that Reactions (ii) to (iv) with their appropriate conversion efficiencies would affect the calculated values of $\mathrm{pH}$ and NOx partitioning in the offgas. Therefore, all the conversion efficiencies shown in Table 2-5 had to be optimized simultaneously.

\subsubsection{Validation of LAW Plenum Combustion Model}

The global kinetic parameters of $\mathrm{CO}$ and $\mathrm{H}_{2}$ combustion in the LAW melter plenum given in Table 2-6 were validated against the data taken during DM1200 B1 run [Matlack, 2003a]. The entire run consisted of two steady state feeding periods, and all the offgas data except for $\mathrm{H}_{2}$ were collected at the melter, SBS and WESP exits and reported as the average values for each steady state period. After carefully examining all relevant operating data including plenum temperature, offgas and particulate analysis, the Method 29 data collected at the $74^{\text {th }}$ and $94^{\text {th }}$ hours were judged to be most representative of a steady state operation and thus used to define the baseline operating conditions for the model validation.

Furthermore, as in the DM1200 A1 run, the concentration of $\mathrm{H}_{2}$ was measured only at the WESP exit, but at two different points in time, $72^{\text {nd }}$ and $97^{\text {th }}$ hour, and these $\mathrm{H}_{2}$ data were assumed to represent those at the $74^{\text {th }}$ and $94^{\text {th }}$ hours as well due to such close proximity of the sampling times. However, since these sampling times all belong to the second steady state feeding period (SS2), the model validation would have to be conducted using the same non-hydrogen offgas data averaged over the entire SS2 period, which would not be considered as such a rigorous validation. 
Additional data were sought to increase the depth of validation data. Such data became available from a special attempt made at the $98^{\text {th }}$ hour to take the gas samples directly from the melter using an air-cooled sampling probe inserted into different heights of the plenum [Matlack, 2003b]. The idea was to quench the gas quickly once drawn into the probe so that its composition would represent something close to that coming off the cold cap. While the plenum gas data thus collected provided an additional opportunity for model validation, the offgas data collected concurrently at the melter exit downstream of the control air entry point could also be used to represent those at the $94^{\text {th }}$ hour as well due to close proximity of the two sampling times.

In the end, it was decided to validate the LAW combustion model against two mixed sets of offgas data; (1) the $74^{\text {th }}$ hour data set consisting of instantaneous $\mathrm{H}_{2}$ data taken at the $72^{\text {nd }}$ hour and the average (non-hydrogen) offgas data taken at the melter, SBS and WESP exits during the second steady state feeding period that lasted 44 hours, and (2) the $94^{\text {th }}$ hour data set consisting of instantaneous $\mathrm{H}_{2}$ data taken at the $97^{\text {th }}$ hour, instantaneous offgas data taken at the melter exit at the $98^{\text {th }}$ hour, and the average offgas data taken at the SBS and WESP exits during the second steady state feeding period. Predicted offgas composition exiting the melter at the $94^{\text {th }}$ hour was also compared against the sampling probe data taken at the $98^{\text {th }}$ hour to infer its effectiveness in achieving its design goal of quenching the gas rapidly.

\subsubsection{Input for Model Validation Run}

As in the DM1200 A1 run, the calcine gas composition predicted by the cold cap model for the Envelope B1 feed was modified to better reflect experimentally observed partitioning of $\mathrm{NO}_{x}$ and $\mathrm{NH}_{3}$ in the offgas. Comparisons are made in Table 2-7 between the pre- and postadjustment values. The DM10 A1 data are also shown for the purpose of comparing the impact of two different feed compositions. Again, the adjusted composition clearly shows considerably less $\mathrm{NO}$ and $\mathrm{N}_{2} \mathrm{O}$ as a result of adding $\mathrm{N}_{2}$. It is also noted that the percent conversion of nitrate/nitrite fed into $\mathrm{NO}_{\mathrm{x}}$ was reduced from the high $86 \%$ to $42 \%$ and, after allowing absorption of $\mathrm{NO} / \mathrm{NO}_{2}$ per Reactions (ii) and (iii), the latter conversion value was found to closely match the $\mathrm{NO}_{\mathrm{x}}$ data taken downstream of the SBS, as shown in the next section. The estimated $42 \%$ conversion of nitrate/nitrite into $\mathrm{NO}_{\mathrm{x}}$ agrees very well with the measured conversion of $40 \%$ during the DM1200 C1 Run [Matlack, 2002a].

One trend worth noting in Table 2-7 is that when expressed in terms of molar ratios with respect to $\mathrm{CO}_{2}$ or $\mathrm{CO}+\mathrm{CO}_{2}$, the predicted concentrations of all flammable gases except for $\mathrm{NH}_{3}$ are lower than those predicted earlier for the Envelope A1 feed by the same factor of 3 . No experimental data are currently available to directly confirm the validity of these latest model results on the Envelope B1 feed. Nevertheless, the predicted trend appears to be in the right direction, considering the fact that although the molar ratio of TOC to the sum of nitrate and nitrite were nearly identical in the two feeds, the absolute TOC content in the Envelope B1 simulant was only $1 / 3$ of that in the baseline Envelope A1 simulant. Some inference can also be made as to the validity of these cold cap model results based on the results of LAW combustion model validation, as shown in the next section. 
WSRC-TR-2003-00285, REVISION 0

SRT-RPP-2003-00130, REVISION 0

Table 2-7. Predicted vs. Adjusted Envelope B1 Calcine Gas Compositions

\begin{tabular}{|c|c|c|c|c|}
\hline & $\begin{array}{r}\text { Cold Cap Model } \\
\text { Output }\end{array}$ & $\begin{array}{l}\text { Adjusted Input to } \\
\text { Combustion Model }\end{array}$ & $\begin{array}{l}\text { DM10 A1 Data } \\
\text { [Matlack, 2003d] }\end{array}$ & Comment on Data \\
\hline & (mole fraction) & (mole fraction) & & \\
\hline calcine $\mathrm{H} 2 \mathrm{O}$ & 0.65333 & 0.66897 & & \\
\hline $\mathrm{CO}$ & 0.00218 & 0.00206 & & \\
\hline $\mathrm{CO}_{2}$ & 0.25243 & 0.23903 & & \\
\hline $\mathrm{H}_{2}$ & 0.00250 & 0.00236 & & \\
\hline NO & 0.05027 & 0.02889 & & \\
\hline $\mathrm{N}_{2} \mathrm{O}$ & 0.01686 & 0.00352 & & \\
\hline $\mathrm{NO}_{2}$ & 0.00025 & 0.00282 & & \\
\hline $\mathrm{NH}_{3}$ & 0.01319 & 0.01249 & & \\
\hline $\mathrm{O}_{2}$ & 0.00522 & 0.01794 & & \\
\hline $\mathrm{N}_{2}$ & 0.00000 & 0.02051 & & \\
\hline $\mathrm{CH}_{4}$ & 0.00148 & 0.00140 & & \\
\hline Total & 0.99770 & 1.00000 & & \\
\hline $\mathrm{CO} / \mathrm{CO}_{2}$ & 0.009 & 0.009 & 0.031 & peak DM10 A1 \\
\hline $\mathrm{H}_{2} /\left(\mathrm{CO}+\mathrm{CO}_{2}\right)$ & 0.010 & 0.010 & 0.027 & $"$ \\
\hline $\mathrm{THC} /\left(\mathrm{CO}+\mathrm{CO}_{2}\right)$ & 0.006 & 0.006 & 0.072 & $"$ \\
\hline $\mathrm{NH}_{3} / \mathrm{NO}_{\mathrm{x}}$ & 0.157 & 0.322 & 0.680 & $"$ \\
\hline $\mathrm{NO}_{x} /\left(\mathrm{NO}_{3}+\mathrm{NO}_{2}\right)$ & 0.86 & 0.42 & 0.51 & DM100 A3 data \\
\hline $\mathrm{NO} / \mathrm{NO}_{\mathrm{x}}$ & 0.746 & 0.82 & 0.78 & average DM10 A1 \\
\hline $\mathrm{N}_{2} \mathrm{O} / \mathrm{NO}_{\mathrm{x}}$ & 0.250 & 0.08 & 0.14 & $"$ \\
\hline $\mathrm{NO}_{2} / \mathrm{NO}_{\mathrm{x}}$ & 0.004 & 0.10 & 0.08 & $"$ \\
\hline
\end{tabular}

Some of the key process data used in the LAW combustion model validation run is shown in Table 2-8. All these data were taken directly from the DM1200 B1 Run report [Matlack, 2003a] and, except for the feed and glass production rates, they represent instantaneous values measured at the indicated run times. One interesting observation to be made is that the total fixed melter air purge during DM1200 melter runs was very small, less than $1 \mathrm{scfm}$, so that without counting the melter air inleakage as part of the combustion air oxygen would have been depleted in the plenum long before burning any significant amounts of flammable gases, whose concentrations are shown in Table 2-3 and Table 2-7. In other words, without taking credit for the melter air inleakage, the prerequisite model condition of maintaining a sufficient level of excess combustion air would have been violated early on. Nevertheless, the analysis made so far in this work has included the melter air inleakage as part of the combustion/dilution air, since the melter pressure during these runs did not fluctuate widely enough to cause the air inleakage to change appreciably. Therefore, whatever the estimated melter air inleakage may be, it had to be included in the analysis in order to match measured temperature, flow and composition data. 
Table 2-8. Process Data Input to LAW Model for DM1200 B1 Run

\begin{tabular}{|lrr|}
\hline & $\mathbf{9 4}^{\text {th }}$ Hour & $\mathbf{7 4}^{\text {th }}$ Hour \\
sugar addition (X A1 Baseline) & 1 & 1 \\
feed rate less sugar ( $\mathrm{kg} / \mathrm{hr})$ & 233 & 216 \\
glass production rate ( $\left.\mathrm{kg} / \mathrm{m}^{2} / \mathrm{day}\right)$ & 2,594 & 2,404 \\
total fixed melter air purge (scfm) & 0.33 & 0.38 \\
film cooler air purge (cfm) & 70 & 70 \\
film cooler air temperature ( $\left.{ }^{\circ} \mathrm{C}\right)$ & 99 & 99 \\
off-gas temp @ film cooler exit $\left({ }^{\circ} \mathrm{C}\right)$ & 300 & 310 \\
pressure control air (scfm) & 35 & 35 \\
off-gas flow in transition pipe (dscfm) & 198.3 & 201.96 \\
$\quad(\%$ moisture) & $26.50 \%$ & $29.12 \%$ \\
SBS exit temperature ( $\left.{ }^{\circ} \mathrm{C}\right)$ & 40 & 40 \\
off-gas flow @ WESP exit (scfm) & 242 & 240 \\
temperature @ WESP exit $\left({ }^{\circ} \mathrm{C}\right)$ & 42 & 42 \\
$\mathrm{H} 2 \mathrm{O}$ spray to WESP (gal/hr) & 1.51 & 1.51 \\
\hline
\end{tabular}

\subsubsection{Results of Model Validation Run}

The key process parameters estimated by the model are shown in Table 2-9 and, when compared to the results shown in Table 2-5, two changes are worth noting. First, despite the fact that the melter pressure remained somewhat higher during the DM1200 B1 run, the estimated melter air inleakage was increased by $30 \%$ over that during the DM1200 A1 run. Noting that the DM1200 B1 run was conducted nine months after the completion of DM1200 A1 run, this estimated increase in air inleakage could be attributed either to the lost seals in and around the melter as a result of any maintenance work done during that time span or to inherent uncertainties of the data used in the calculations.

Second, the difference between the indicated and true gas temperatures in the plenum was increased from 35 to $45^{\circ} \mathrm{C}$. This means that at the same indicated plenum temperature the true gas temperature would have been $10{ }^{\circ} \mathrm{C}$ lower during the DM1200 B1 run than during the DM1200 A1 run, and this reduction in gas temperature could very well have been due to increased air inleakage during the DM1200 B1 run. It is also interesting to note that despite the lower gas temperature, the gas residence time in the plenum during the DM1200 B1 run was estimated to be shorter than that during the DM1200 A1 run. This occurred because the total mass inflow including free water in the feed and again melter air inleakage was higher during the DM1200 B1 run. Hence, it cannot be emphasized enough that both melter air inleakage and true plenum gas temperature will have a profound impact on the outcome of flammability assessment by affecting everything from combustion kinetics to dilution one way or another and, therefore, accurate estimation of their values is crucial to the success of this work. 
WSRC-TR-2003-00285, REVISION 0

SRT-RPP-2003-00130, REVISION 0

Table 2-9. Estimated Process Parameters During DM1200 B1 Run

\begin{tabular}{|c|c|c|c|c|}
\hline & \multicolumn{2}{|c|}{$94^{\text {th }}$ Hour } & \multicolumn{2}{|c|}{$74^{\text {th }}$ Hour } \\
\hline & LAW Model & Data & LAW Model & Data \\
\hline melter air inleakage (scfm) & 101 & & 105 & \\
\hline plenum gas temperature $\left({ }^{\circ} \mathrm{C}\right)$ & 356 & 400 & 369 & 415 \\
\hline measured - calculated temp $\left({ }^{\circ} \mathrm{C}\right)$ & 44 & & 46 & \\
\hline residence time in plenum (sec) & 6.8 & & 6.7 & \\
\hline off-gas temp inc. control air $\left({ }^{\circ} \mathrm{C}\right)$ & 268 & & 276 & \\
\hline off-gas temp @ SBS inlet $\left({ }^{\circ} \mathrm{C}\right)$ & & 250 & & 250 \\
\hline T drop across transit'n pipe $\left({ }^{\circ} \mathrm{C}\right)$ & 18 & & 26 & \\
\hline airleak into SBS/WESP (scfm) & 12.2 & & 6.8 & \\
\hline
\end{tabular}

The predicted offgas compositions at the melter, SBS and WESP exits are next compared in Table 2-10 to the corresponding DM1200 B1 data. Overall, both predicted and measured concentrations of all listed species are seen to be in excellent agreement at all sampling locations. Among the three data sets shown, the data taken at the melter exit are particularly valuable, since they can be used to determine the true combustion efficiencies in the melter, assuming that the cold cap model predictions or their modified forms were correct or to infer the true cold cap offgas compositions by accurately modeling the combustion kinetics.

For example, the predicted concentration of $\mathrm{NH}_{3}$ at the 94 th hour is seen to be very close to its measured value, if $90 \%$ of $\mathrm{NH} 3$ produced in the cold cap is assumed to burn in the plenum. However, despite the lower plenum gas temperature during the DM1200 B1 run (by $\sim 10^{\circ} \mathrm{C}$ ), this estimated combustion efficiency is a good deal higher than $72.5 \%$ estimated earlier for the A1 feed. This could only mean that the inlet concentration of $\mathrm{NH}_{3}$ used in the DM1200 B1 run simulation was higher than the actual value. In Table 2-7, the absolute concentration of $\mathrm{NH}_{3}$ predicted by the cold cap model is seen to be slightly higher than the adjusted value, which indicates that the cold cap model appeared to have over predicted the concentration of $\mathrm{NH}_{3}$ in the first place. In addition, the overall combustion efficiency of $\mathrm{H}_{2}$ was predicted to be less than $70 \%$ at the 94 th hour. Therefore, considering the fact that the LFL for $\mathrm{NH}_{3}$ is 4 times that of $\mathrm{H}_{2}$, the true combustion efficiency of $\mathrm{NH}_{3}$ should have been well below 70\%. Nevertheless, the estimated combustion efficiency of $90 \%$ for $\mathrm{NH}_{3}$ is still valid, as long as the input fuel is assumed to have the composition shown in Table 2-7.

The overall carbon balance during the DM1200 B1 run was slightly better than that during the DM1200 A1 run; however, the discrepancy between the measured concentrations of CO and $\mathrm{CO}_{2}$ combined and those calculated still ranged from 17 to $30 \%$. For this reason, the validation of the global kinetic models of $\mathrm{CO}$ and $\mathrm{H}_{2}$ combustion was done by comparing the molar ratio of $\mathrm{CO} / \mathrm{CO}_{2}$ and the absolute concentration of $\mathrm{H}_{2}$ at the WESP exit, after adding a small amount of air inleakage to the SBS/WESP to match the measured offgas flow. The amount of air inleakage thus added was practically the same as that added during the DM1200 A1 run simulation, which is an indication that the data used for the validation were consistent, and the model used to simulate the actual run conditions was adequate. 
WSRC-TR-2003-00285, REVISION 0

SRT-RPP-2003-00130, REVISION 0

Table 2-10. Comparison of Offgas Compositions Predicted by LAW Melter Combustion Model vs. DM1200 B1 Data

\begin{tabular}{|c|c|c|c|c|}
\hline & \multicolumn{2}{|c|}{$94^{\text {th }}$ Hour } & \multicolumn{2}{|c|}{$74^{\text {th }}$ Hour } \\
\hline & LAW Model & Data & LAW Model & Data \\
\hline \multicolumn{5}{|l|}{ plenum combustion } \\
\hline conversion of $\mathrm{NH}_{3}$ via $\mathrm{Rxn}$ (iv) & $90.0 \%$ & & $90.0 \%$ & \\
\hline \multicolumn{5}{|l|}{ off-gas composition @ melter exit } \\
\hline $\mathrm{H}_{2} \mathrm{O}(\%)$ & $26.1 \%$ & $24.0 \%$ & $24.3 \%$ & $26.0 \%$ \\
\hline $\mathrm{CO}_{2}(\%)$ & $1.6 \%$ & $1.3 \%$ & $1.5 \%$ & $1.3 \%$ \\
\hline $\mathrm{CO}$ (ppmv) & 115 & 109 & 102 & 109 \\
\hline $\mathrm{H}_{2}$ (ppmv) & 51 & $\mathrm{n} / \mathrm{a}$ & 37 & $\mathrm{n} / \mathrm{a}$ \\
\hline NO (ppmv) & 2759 & 2807 & 2572 & 2800 \\
\hline $\mathrm{N}_{2} \mathrm{O}$ (ppmv) & 242 & 241 & 226 & 230 \\
\hline $\mathrm{NO}_{2}$ (ppmv) & 194 & 183 & 181 & 170 \\
\hline $\mathrm{NH}_{3}(\mathrm{ppmv})$ & 86 & 82 & 80 & 63 \\
\hline $\mathrm{CO}+\mathrm{CO}_{2}$ (ppmv) & 16577 & 13109 & 15449 & 13109 \\
\hline $\mathrm{CO} / \mathrm{CO} 2$ & 0.0070 & 0.0084 & 0.0066 & 0.0085 \\
\hline \multicolumn{5}{|l|}{ SBS chemistry adjustment } \\
\hline conversion of Reaction (ii) & $15.0 \%$ & & $15.0 \%$ & \\
\hline \multirow{2}{*}{\multicolumn{5}{|c|}{ off-gas composition @ SBS exit }} \\
\hline & & & & \\
\hline $\mathrm{H}_{2} \mathrm{O}(\%)$ & $7.3 \%$ & $7.2 \%$ & $7.3 \%$ & $7.2 \%$ \\
\hline $\mathrm{CO}_{2}(\%)$ & $2.1 \%$ & $1.6 \%$ & $1.9 \%$ & $1.6 \%$ \\
\hline $\mathrm{CO}$ (ppmv) & 144 & 120 & 125 & 120 \\
\hline $\mathrm{H}_{2}$ (ppmv) & 65 & $\mathrm{n} / \mathrm{a}$ & 45 & $\mathrm{n} / \mathrm{a}$ \\
\hline NO (ppmv) & 2945 & 2700 & 2680 & 2700 \\
\hline $\mathrm{N}_{2} \mathrm{O}($ ppmv) & 304 & 320 & 277 & 320 \\
\hline $\mathrm{NO}_{2}$ (ppmv) & 725 & 630 & 660 & 630 \\
\hline $\mathrm{NH}_{3}$ (ppmv) & 0 & 10 & 0 & 10 \\
\hline $\mathrm{CO}+\mathrm{CO}_{2}$ (ppmv) & 20725 & 16120 & 18855 & 16120 \\
\hline $\mathrm{CO} / \mathrm{CO} 2$ & 0.0070 & 0.0075 & 0.0067 & 0.0075 \\
\hline \multicolumn{5}{|l|}{ WESP chemistry adjustment } \\
\hline conversion of Reaction (ii) & $15.0 \%$ & & $15.0 \%$ & \\
\hline conversion of Reaction (iii) & $18.0 \%$ & & $18.0 \%$ & \\
\hline \multicolumn{5}{|l|}{ off-gas composition @ WESP exit } \\
\hline $\mathrm{H}_{2} \mathrm{O}(\%)$ & $6.6 \%$ & $6.5 \%$ & $6.6 \%$ & $6.5 \%$ \\
\hline $\mathrm{CO}_{2}$ (ppmv) & 19530 & 15000 & 18253 & 15000 \\
\hline $\mathrm{CO}$ (ppmv) & 136 & 100 & 122 & 100 \\
\hline $\mathrm{H}_{2}$ (ppmv) & 61 & 49 & 44 & 34 \\
\hline NO (ppmv) & 2433 & 2200 & 2274 & 2200 \\
\hline $\mathrm{N}_{2} \mathrm{O}$ (ppmv) & 289 & 300 & 270 & 300 \\
\hline $\mathrm{NO}_{2}$ (ppmv) & 916 & 850 & 856 & 850 \\
\hline $\mathrm{NH}_{3}$ (ppmv) & 0 & 1 & 0 & 1 \\
\hline $\mathrm{CO}+\mathrm{CO}_{2}$ (ppmv) & 19667 & 15100 & 18375 & 15100 \\
\hline $\mathrm{CO} / \mathrm{CO} 2$ & 0.00699 & 0.00667 & 0.00668 & 0.00667 \\
\hline
\end{tabular}


It is also shown in Table 2-10 that the LAW combustion model somewhat under predicted the combustion efficiency of $\mathrm{H}_{2}$, resulting in $25-30 \%$ higher predicted concentrations of $\mathrm{H}_{2}$ than the measured values, which is conservative from the offgas flammability standpoint. On the other hand, the predicted molar ratios of $\mathrm{CO}$ to $\mathrm{CO}_{2}$ were nearly identical to those measured at the WESP exit.

The model was also run under the prevailing conditions at the $98^{\text {th }}$ hour of DM1200 B1 run, and the predicted composition of the melter exhaust after combustion is compared in Table 2-11 against the sampling probe data. The overall carbon balance is again shown to be not good with a discrepancy of $27 \%$, so the molar ratio of $\mathrm{CO} / \mathrm{CO}_{2}$ is the preferred validation variable over the absolute concentration of $\mathrm{CO}$. The predicted concentrations of all nonflammable gases except $\mathrm{CO}_{2}$ are seen to be all within $10 \%$ of the data, which is another indication of data consistency and the adequacy of the LAW melter combustion model.

As for the flammable gases, the predicted concentrations of $\mathrm{H}_{2}$ and $\mathrm{CO}$ (as the molar ratio of $\mathrm{CO} / \mathrm{CO}_{2}$ ) are seen to be lower than the measured data using the sampling probe by $30-39 \%$. This trend was expected, since the probe data were supposed to represent the unburned cold cap composition. However, it appears that the stated relative differences are not large enough considering that the predicted concentration of $\mathrm{H}_{2}$ at $40 \mathrm{ppm}$ was based on an estimated overall combustion efficiency of $84 \%$ under the prevailing conditions at the $98^{\text {th }}$ hour. This could only mean that although the intent of the air-cooled sampling probe was to stop any reactions inside the probe, the entering gas had already reacted or continued to react inside the probe. Based on the initial $\mathrm{H}_{2}$ concentration of $250 \mathrm{ppm}$ prior to any combustion, the measured concentration of $\mathrm{H}_{2}$ at $66 \mathrm{ppm}$ would represent an overall combustion efficiency of $75 \%$, which indicates that the probe did cool the gas to some degree but the resulting gas sample was far from that coming off the cold cap. Regarding the third flammable gas $\mathrm{NH}_{3}$, its measured concentrations at the melter exit given in Table 2-10 are lower than that given in Table 2-11, since the former data included the film cooler air, while the latter did not.

Table 2-11. Predicted Melter Exhaust Composition vs. Plenum Sampling Probe Data during DM1200 B1 Run

\begin{tabular}{|lrrr|}
\hline & Model & Data & $\begin{array}{r}\text { \% Difference } \\
\text { (w.r.t data) }\end{array}$ \\
$\mathrm{H}_{2} \mathrm{O}(\%)$ & & & \\
$\mathrm{CO}$ & & $36.0 \%$ & $9.6 \%$ \\
$\mathrm{CO}(\mathrm{ppmpm})$ & $39.5 \%$ & 19550 & $27.4 \%$ \\
$\mathrm{H}_{2}(\mathrm{ppmv})$ & 24907 & 174 & $-11.3 \%$ \\
$\mathrm{NO}(\mathrm{ppmv})$ & 154 & 66 & $-39.3 \%$ \\
$\mathrm{~N}_{2} \mathrm{O}(\mathrm{ppmv})$ & 40 & 4166 & $0.1 \%$ \\
$\mathrm{NO}_{2}(\mathrm{ppmv})$ & 4172 & 400 & $-8.4 \%$ \\
$\mathrm{NH}_{3}(\mathrm{ppmv})$ & 366 & 313 & $-6.4 \%$ \\
$\mathrm{CO}+\mathrm{CO}(\mathrm{ppmv})$ & 293 & 116 & $11.9 \%$ \\
$\mathrm{CO} / \mathrm{CO}_{2}$ & 130 & 19724 & $27.1 \%$ \\
& 25061 & 0.0089 & $-30.4 \%$ \\
\hline
\end{tabular}




\subsection{SAFETY SIMULATION}

The validated LAW melter combustion model was run to simulate several accident scenarios involving over-batching of sugar and offgas surges. Specifically, these safety case studies were conducted in stages.

In Stage 1, the effects of sugar over-batching up to $4 \mathrm{X}$ nominal and the melter operating modes on the offgas flammability were assessed independently in order to determine the maximum sugar levels that can be tolerated under normal and upset conditions at the given baseline fixed melter air purge of $101 \mathrm{scfm}$. The two operating modes considered were normal and transient operation induced by an offgas surge. The peak intensity of offgas surge was set at $7 \mathrm{X} / 3 \mathrm{X}$, representing $7 \mathrm{X}$ nominal condensable (steam generated from free $\mathrm{H}_{2} \mathrm{O}$ in feed) and $3 \mathrm{X}$ nominal non-condensable (calcine gas) flows, respectively.

In Stage 2, the effect of varying air purge on the offgas flammability was assessed under the conditions of simultaneous sugar over-batching and offgas surge at the melter plenum temperatures of the nominal $400{ }^{\circ} \mathrm{C}$ and the projected minimum of $300{ }^{\circ} \mathrm{C}$.

Finally, in Stage 3, the degree of sugar over-batching that would result in $25 \%$ of the CLFL at the SBS exit was determined under the conservative operating scenario of $7 \mathrm{X} / 3 \mathrm{X}$ offgas surge and at the minimum air purge and minimum melter plenum temperature.

Since the projected list of flammable gases in the noncondensable LAW melter exhaust includes $\mathrm{H}_{2}, \mathrm{CO}$, and $\mathrm{CH}_{4}$ representing the $\mathrm{HC}$ species, the resulting flammability potential of each case was calculated in terms of percent of the composite LFL (CLFL):

\section{Equation 11}

$$
\% \text { CLFL }=100\left(\frac{\left[\mathrm{H}_{2}\right]}{L F L_{\mathrm{H}_{2}}}+\frac{[\mathrm{CO}]}{L F L_{\mathrm{CO}}}+\frac{\left[\mathrm{CH}_{4}\right]}{\mathrm{LFL}_{\mathrm{CH}_{4}}}\right)
$$

where the concentrations are given in volume percent, and the LFLs for $\mathrm{H}_{2}, \mathrm{CO}$, and $\mathrm{CH}_{4}$ are given as 4, 12.5 and 5 volume percent, respectively [Lide, 2002]. 


\subsubsection{Bases of Case Studies}

Some of the key bases used in the safety simulation runs include:

1. The Envelope A1 simulant for Tank AN-105 developed at VSL was used as the baseline feed for the simulation [Matlack, 2002b]. The sugar level in the Envelope A1 simulant is referred here to as "1X nominal sugar."

The choice of Envelope A1 over Envelope C1, despite much higher levels of organic waste constituents in the latter, was made based on the fact that the sugar content of the former was much higher than that of the latter, and one of the accident scenarios of interest to this work was inadvertent over-batching of sugar.

2. The adjusted calcine gas composition shown in Table 2-3 was used as the incoming fuel composition to the combustion model, excluding free water in the feed, for the $1 \mathrm{X}$ nominal sugar case. The feed rate was set to match the design basis glass production rate of 15 metric tons per day.

3. For feeds containing higher-than-1X nominal sugar, the calcine gas compositions predicted by the cold cap model were adjusted by setting the percent conversion of nitrate/nitrite in the feed into $\mathrm{NO}_{\mathrm{x}}$ at $24 \%, 16 \%$, and $14 \%$ for the $2 \mathrm{X}, 3 \mathrm{X}$, and $4 \mathrm{X}$ nominal sugar feeds, respectively, based on the DM100 A3 data (see Figure 2-27) [Matlack, 2003c]. The resulting calcine gas compositions used as the input to each simulation runs with over-batched sugar are shown in Appendix C.

4. The overall combustion efficiency of $\mathrm{NH}_{3}$ in the melter plenum via Reaction (iv) was set at $72.5 \%$, as shown in Table $2-5$.

5. Methane used to represent the THC data is just as flammable as hydrogen; however, methane was not allowed to burn in the melter plenum, thus rendering the resulting offgas more flammable.

6. The air purges to the LAW melter combustion model included two types:

Fixed air purges:

- $5 \mathrm{scfm}$ to bubblers

- 4 scfm to air lift lances

- $30 \mathrm{scfm}$ backup offgas duck purge

- $50 \mathrm{scfm}$ plenum viewing CCTV purge

- $10 \mathrm{scfm}$ film cooler cleaner purge

- 2 scfm ADS pump blowdown

Variable air purge:

- $300 \mathrm{scfm}$ melter air inleakage

7. Regardless of whether the melter air inleakage was included as part of the combustion and dilution air, it was included in the calculation of plenum gas residence time. 


\section{WSRC-TR-2003-00285, REVISION 0 SRT-RPP-2003-00130, REVISION 0}

8. The air purge to the LAW melter film cooler was set at $170 \mathrm{cfm}$, and its temperature was set at $99{ }^{\circ} \mathrm{C}$, as measured during the DM1200 A1 run [Matlack, 2002b]. The film cooler air is one of the primary sources of dilution air. Therefore, it was implicitly assumed that the LAW melter would not pressurize above -0.5 inches $\mathrm{H}_{2} \mathrm{O}$ under the conditions of case studies considered in this work.

9. Except during Stage 2 case studies, the LAW melter pressure control air, nominally set at $300 \mathrm{scfm}$, was not included as part of the dilution air, since it constantly modulates to dampen the fluctuations in melter pressure.

10. The $7 \mathrm{X} / 3 \mathrm{X}$ offgas surge was assumed to occur as follows: At $\mathrm{t}=0$, the flow rates of condensable and non-condensable gases start to ramp up to the peak values of $7 \mathrm{X}$ and $3 \mathrm{X}$ nominal, respectively, during the first 22 seconds. Then, they immediately ramp down back to $1 \mathrm{X}$ nominal during the next 89 seconds.

11. The nominal temperature of the LAW melter plenum, as measured in the thermowell, was set at $400{ }^{\circ} \mathrm{C}$ with the lower bound of $300{ }^{\circ} \mathrm{C}$. Based on the results of DM1200 data analysis, the true gas temperature exiting the melter was assumed to be $40{ }^{\circ} \mathrm{C}$ lower at the indicated reading of $400{ }^{\circ} \mathrm{C}$ with this difference between the indicated and true gas temperatures decreasing to zero at the indicated reading of $200{ }^{\circ} \mathrm{C}$.

12. Before each transient run, a steady state combustion model was run first for each case to estimate the radiant heat input into the plenum, which was then assumed to remain constant during the 111-second offgas surge simulation.

13. The point of offgas flammability assessment was set at the SBS exit, where the concentration of flammable gases would be at its maximum after steam condensation.

A brief description is given next on how various $\mathrm{NO}_{\mathrm{x}}$ profiles (shown in Figure 2-27) were generated. First, the measured $\mathrm{NO}_{\mathrm{x}}$ partitioning data for the Envelope $\mathrm{A} 3$ feed were plotted from $1 \mathrm{X}$ to $2.5 \mathrm{X}$ nominal sugar at $0.5 \mathrm{X}$ nominal increments. Each $\mathrm{A} 3$ data set was regressed next and the best-fitting curve was extrapolated to $4 \mathrm{X}$ nominal sugar. The mathematical expressions of the resulting regression curves are given in Eqs. (12) to (14). Finally, the $\mathrm{NO}_{\mathrm{x}}$ profiles for the Envelope A1 feed were drawn from their measured data at $1 \mathrm{X}$ nominal sugar by maintaining the same slopes as in the $\mathrm{A} 3$ data at each $0.5 \mathrm{X}$ nominal jump.

\section{Equation 12}

Equation 13

Equation 14

$$
\operatorname{Vol} \%(N O-A 3)=e^{4.437} X^{-0.0668}, \quad R^{2}=0.987
$$

$$
\operatorname{Vol} \%\left(N O_{2}-A 3\right)=e^{1.789} X^{-1.4804}, \quad R^{2}=0.954
$$

$$
\operatorname{Vol} \%\left(N_{2} O-A 3\right)=e^{2.323} X^{0.7106}, \quad R^{2}=0.991
$$

where $\mathrm{X}$ represents the ratio of a given sugar level to the nominal. 
WSRC-TR-2003-00285, REVISION 0

SRT-RPP-2003-00130, REVISION 0

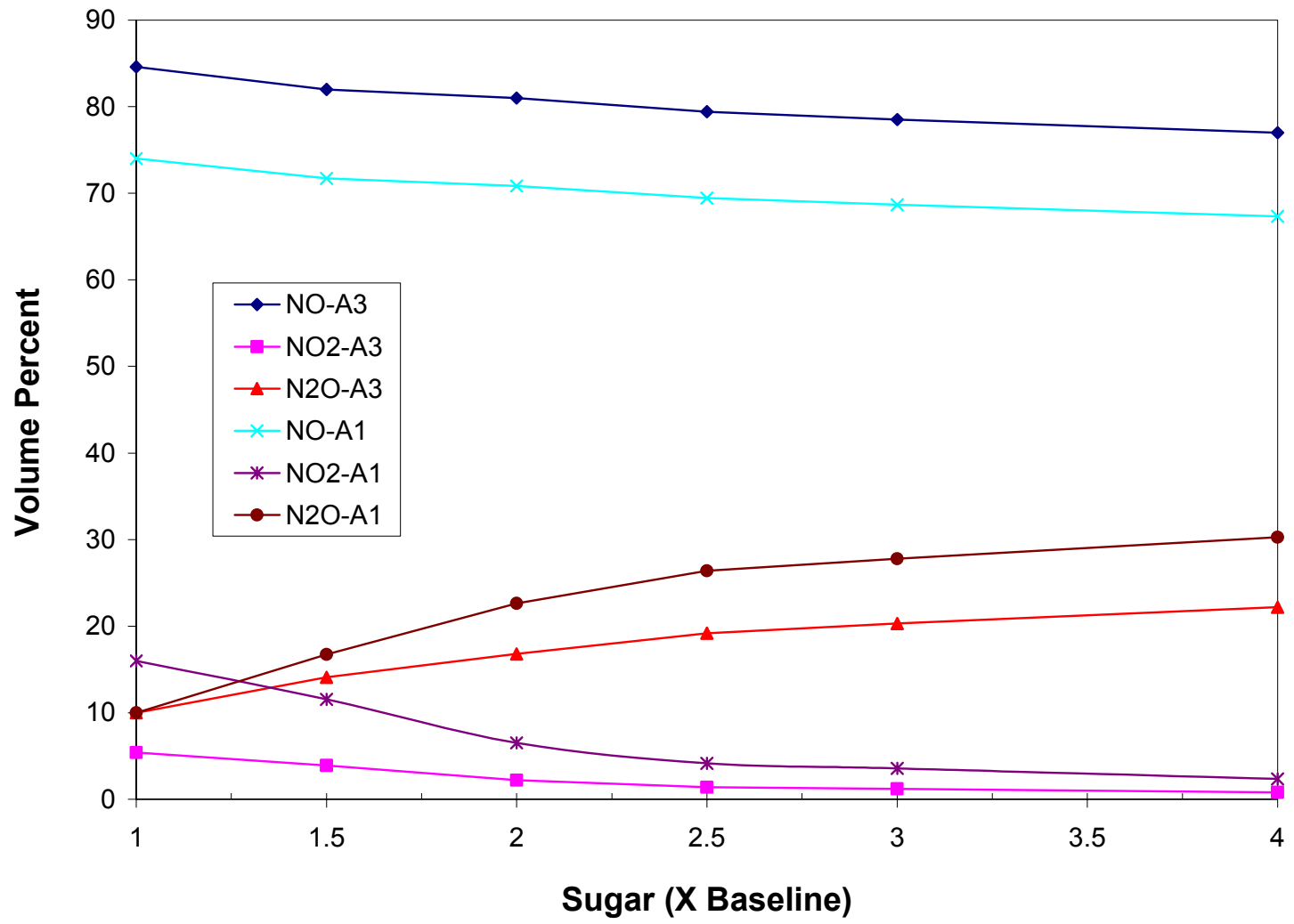

Figure 2-27. $\mathrm{NO}_{\mathrm{x}}$ Partitioning at Varying Sugar Levels

\subsubsection{Safety Simulation Results}

The results of several safety simulation runs made are presented next.

\subsubsection{Stage 1 Case Study}

A total of 16 cases were run at the indicated melter plenum temperature of $400{ }^{\circ} \mathrm{C}$ and by not counting the melter pressure control air as the dilution source. The adjusted calcine gas compositions for the $2 \mathrm{X}, 3 \mathrm{X}$ and $4 \mathrm{X}$ nominal sugar feeds are shown in Tables C-2, C-3, and $\mathrm{C}-4$, respectively, in Appendix $\mathrm{C}$ along with the corresponding cold cap model predictions. The total combustion air purge, including the stoichiometric amount of air required to burn $100 \%$ of the flammable gases in each of these input streams plus the required amount of excess air, was calculated first prior to the LAW combustion model runs. Figure 2-28 shows that if melter air inleakage is not included as part of the combustion air, the baseline fixed melter air purge of $101 \mathrm{scfm}$ is only adequate up to $1.6 \mathrm{X}$ nominal sugar or $60 \%$ overbatching to satisfy the minimum $50 \%$ excess air requirement. It is also shown that if melter air inleakage is included as part of the combustion air, the total melter air purge of $401 \mathrm{scfm}$ is then sufficient to satisfy the minimum $50 \%$ excess air requirement for up to $3.9 \mathrm{X}$ nominal sugar or $290 \%$ over-batching. 
If the minimum excess air requirement is lowered from 50 to $20 \%$, Figure 2-29 shows that the baseline fixed air purge is adequate up to $1.8 \mathrm{X}$ nominal sugar or $80 \%$ over-batching. If melter air inleakage is included as part of the combustion air, then the total melter air purge is adequate well beyond $4 \mathrm{X}$ nominal sugar or over $300 \%$ over-batching. These results clearly show the strong impact that melter air inleakage has on satisfying the excess air requirement, since it constitutes $75 \%$ of the total melter air purge available for combustion.

Table 2-12 shows the predicted offgas flammability at the SBS exit at various sugar levels both with and without melter air inleakage. In some cases where melter air inleakage was not counted as the combustion air, the minimum $20 \%$ excess combustion air requirement was not met, so the model was not run. In such cases, the flammability predictions are given as not applicable (n/a). When the melter air inleakage was counted as a dilution source, the offgas flammability potential was effectively reduced by $50 \%$ for up to $80 \%$ over-batching. As expected, the offgas flammability was shown to increase with increasing sugar level during normal operation and, at $4 \mathrm{X}$ nominal sugar, the predicted flammability potential of the SBS vent was $40 \%$ of the CLFL, including the melter air inleakage (Case 14).

Table 2-12. Results of Stage 1 Case Study for LAW Melter Offgas Flammability Assessment

\begin{tabular}{|c|c|c|c|c|c|c|c|c|}
\hline $\begin{array}{c}\text { Case } \\
\#\end{array}$ & $\begin{array}{c}\text { Offgas } \\
\text { Surges } \\
\text { X } \\
\text { Nominal }\end{array}$ & $\begin{array}{c}\text { Sugar } \\
\text { Level X } \\
\text { Nominal }\end{array}$ & $\begin{array}{c}\text { Melter } \\
\text { Air } \\
\text { Inleakage } \\
(\mathrm{scfm})\end{array}$ & $\begin{array}{c}\text { Fixed } \\
\text { Air } \\
\text { Purges } \\
(\text { scfm })\end{array}$ & $\begin{array}{c}\text { Excess } \\
\text { Combustion } \\
\text { Air } \\
\text { (\% Stoich. })\end{array}$ & $\begin{array}{c}\text { Film } \\
\text { Cooler } \\
\text { Air } \\
(\mathrm{scfm})\end{array}$ & $\begin{array}{c}\text { Pressure } \\
\text { Control } \\
\text { Air } \\
(\mathrm{scfm})\end{array}$ & $\begin{array}{c}\text { Flammable } \\
\text { Gas Conc. } \\
\text { @ SBS } \\
(\% \text { CLFL) }\end{array}$ \\
\hline 1 & $1 / 1$ & 1 & 0 & 101 & 221 & 161 & 0 & 4.6 \\
\hline 2 & $1 / 1$ & 1 & 300 & 101 & 1174 & 161 & 0 & 2.3 \\
\hline 3 & $1 / 1$ & 1.6 & 0 & 101 & 50 & 161 & 0 & 14.4 \\
\hline 4 & $1 / 1$ & 1.6 & 300 & 101 & 495 & 161 & 0 & 7.3 \\
\hline 5 & $1 / 1$ & 1.8 & 0 & 101 & 20 & 161 & 0 & 19.0 \\
\hline 6 & $1 / 1$ & 1.8 & 300 & 101 & 377 & 161 & 0 & 9.6 \\
\hline 7 & $1 / 1$ & 2 & 0 & 101 & 9 & 161 & 0 & $\mathrm{n} / \mathrm{a}$ \\
\hline 8 & $1 / 1$ & 2 & 300 & 101 & 333 & 161 & 0 & 10.8 \\
\hline 9 & $1 / 1$ & 3 & 0 & 101 & -46 & 161 & 0 & $\mathrm{n} / \mathrm{a}$ \\
\hline 10 & $1 / 1$ & 3 & 300 & 101 & 114 & 161 & 0 & 24.0 \\
\hline 11 & $1 / 1$ & 3.9 & 0 & 101 & -62 & 161 & 0 & $\mathrm{n} / \mathrm{a}$ \\
\hline 12 & $1 / 1$ & 3.9 & 300 & 101 & 50 & 161 & 0 & 38.1 \\
\hline 13 & $1 / 1$ & 4 & 0 & 101 & -64 & 161 & 0 & $\mathrm{n} / \mathrm{a}$ \\
\hline 14 & $1 / 1$ & 4 & 300 & 101 & 43 & 161 & 0 & 40.4 \\
\hline 15 & $7 / 3$ & 1 & 0 & 101 & 407 & 161 & 0 & 19.6 \\
\hline 16 & $7 / 3$ & 1 & 300 & 101 & 455 & 161 & 0 & 11.0 \\
\hline
\end{tabular}

When the sugar level was doubled from $1 \mathrm{X}$ to $2 \mathrm{X}$ nominal, the flammability potential of the SBS vent increases by $370 \%$ (Case 2 vs. 8). Subsequent increases in sugar from $2 \mathrm{X}$ to $3 \mathrm{X}$ nominal and from $3 \mathrm{X}$ to $4 \mathrm{X}$ nominal resulted in 120 and $76 \%$ relative increases in the offgas flammability potential, respectively, all including the melter air inleakage of $300 \mathrm{scfm}$ just to satisfy the minimum excess air requirement. 
WSRC-TR-2003-00285, REVISION 0

SRT-RPP-2003-00130, REVISION 0

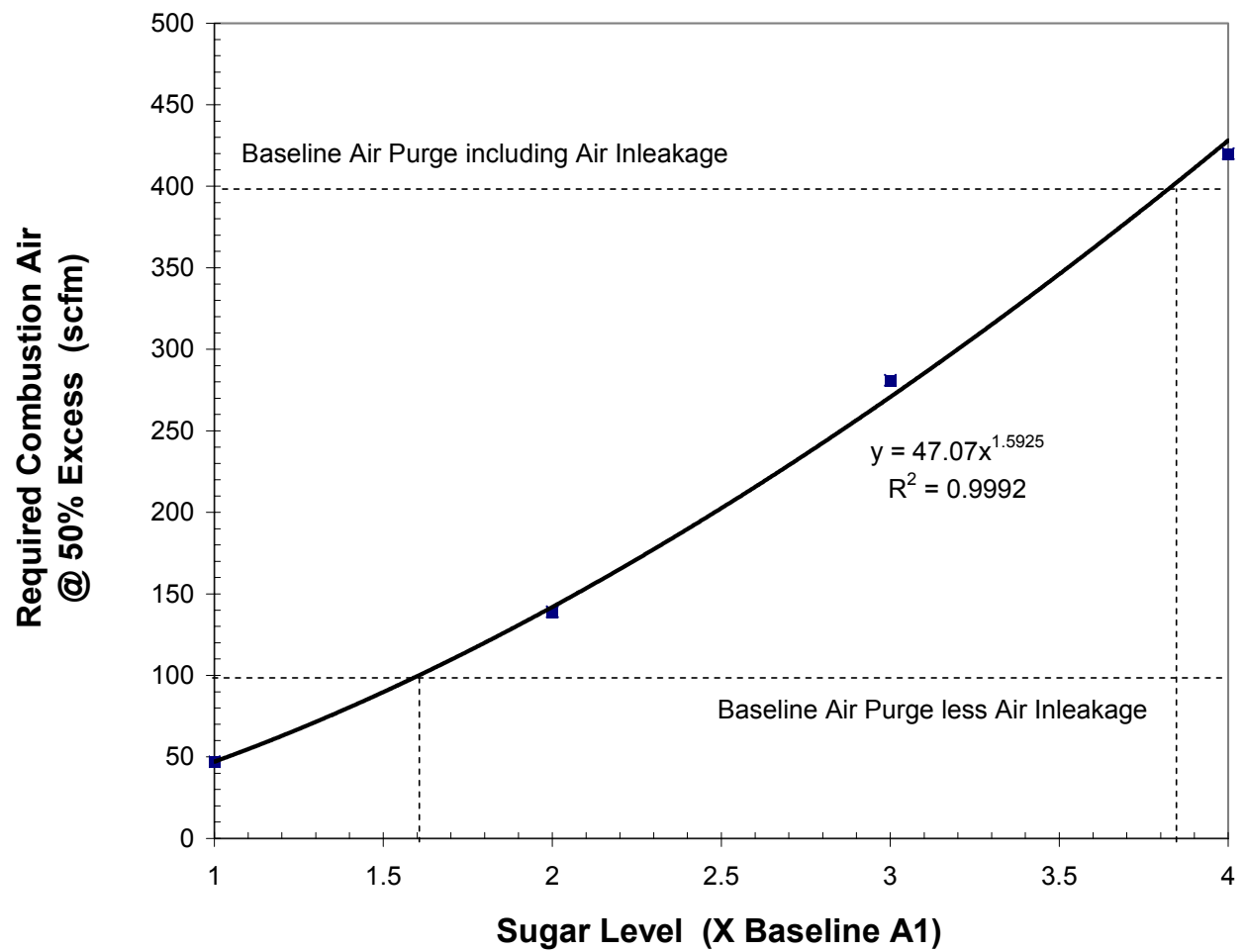

Figure 2-28. Required Combustion Air at 50\% in Excess of Stoichiometric Amount

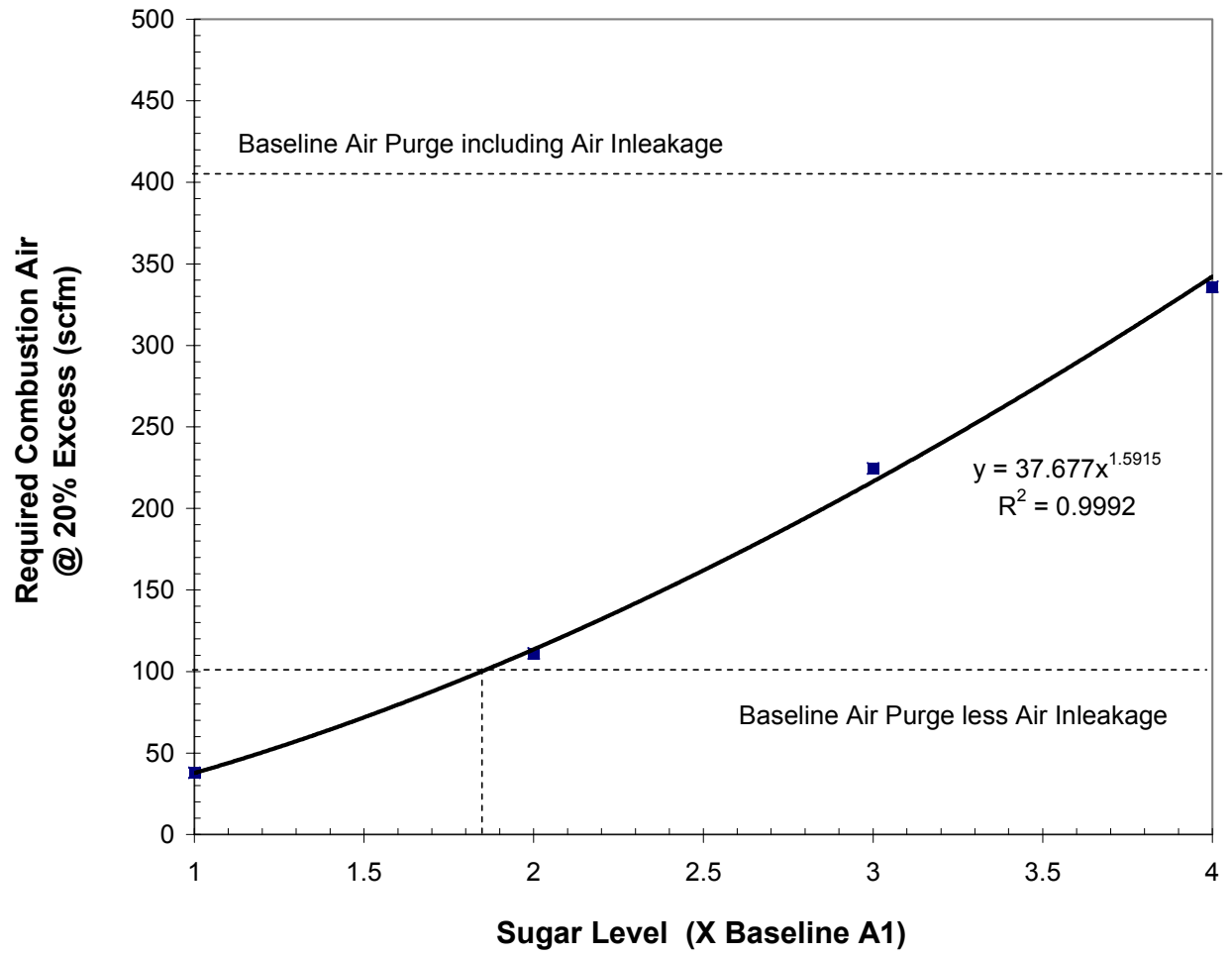

Figure 2-29. Required Combustion Air at 20\% in Excess of Stoichiometric Amount 


\section{WSRC-TR-2003-00285, REVISION 0 SRT-RPP-2003-00130, REVISION 0}

It is to be noted that all these flammability predictions based on the CLFL are conservative, since they include the contribution by methane, whose combustion in the melter was $100 \%$ suppressed, as described earlier. Additional calculations showed that methane contributes to nearly $60 \%$ of the CLFL at $1 \mathrm{X}$ nominal sugar and its contribution decreases to still $40 \%$ at $4 \mathrm{X}$ nominal sugar. These large contributions by methane to the flammability predictions should be more than enough to compensate for any potential for reduced conservatism due to the fact that the concentration of methane predicted by the cold cap model did not bound all VSL data.

Calculations also showed that the fixed melter air purge without air inleakage has to be increased from 101 to $420 \mathrm{scfm}$, if the $50 \%$ excess combustion air requirement is to be met at $4 \mathrm{X}$ nominal sugar or $300 \%$ over-batching. With this increase in fixed air purge and $4 \mathrm{X}$ nominal sugar feed, the flammability potential of the SBS vent was predicted to be $44 \%$ of the CLFL. If the minimum excess combustion air requirement is lowered from 50 to $20 \%$, the necessary fixed air purge is decreased to $336 \mathrm{scfm}$ at $4 \mathrm{X}$ nominal sugar.

Figure 2-30 shows the results of $7 \mathrm{X} / 3 \mathrm{X}$ offgas surge simulation. As described earlier, the surge was assumed to consist of $7 \mathrm{X}$ nominal condensable and $3 \mathrm{X}$ nominal non-condensable flows. The composition of non-condensable flow is given in Table 2-3 and it remained constant throughout the duration of surge. The condensable flow is $100 \%$ steam due to free water in the feed. Due to the limitations of the CHEMKIN software, however, these two flows were combined into one stream, called offgas flow, for the simulation purposes, and the resulting time-profile of the combined $7 \mathrm{X} / 3 \mathrm{X}$ surge is shown in Figure 2-30.

During the first 20 seconds, both the offgas flow and plenum gas temperature are shown to remain at their respective steady state values. The offgas flow then ramps up by a factor of $\sim 5$ to near $900 \mathrm{~g} / \mathrm{sec}$ during the next 22 seconds. It is noted that this $5 \mathrm{X}$ increase in offgas flow lies near the midpoint between $7 \mathrm{X}$ and $3 \mathrm{X}$ original surge magnitudes. The offgas flow contains steam by over $50 \mathrm{wt} \%$ and enters the plenum at near the boiling point of water. Therefore, the surge quickly cools the plenum, and the minimum plenum gas temperature near the peak of surge is shown to be only $456 \mathrm{~K}$ or $183{ }^{\circ} \mathrm{C}$, which is too low a temperature for any combustion reaction to proceed at any appreciable rate. This sudden drop in gas temperature coupled with a sharp increase in flammable gas flows pushes the concentration of flammable gases at the SBS exit from the initial value of near 5\% of the CLFL to a peak value of near $20 \%$ of the CLFL, when melter air inleakage was not counted as part of the combustion and dilution air. When melter air inleakage was included, the entire flammability profile is seen to be reduced by roughly $50 \%$, which again shows how significant the impact of melter air inleakage is in the overall flammability assessment. 


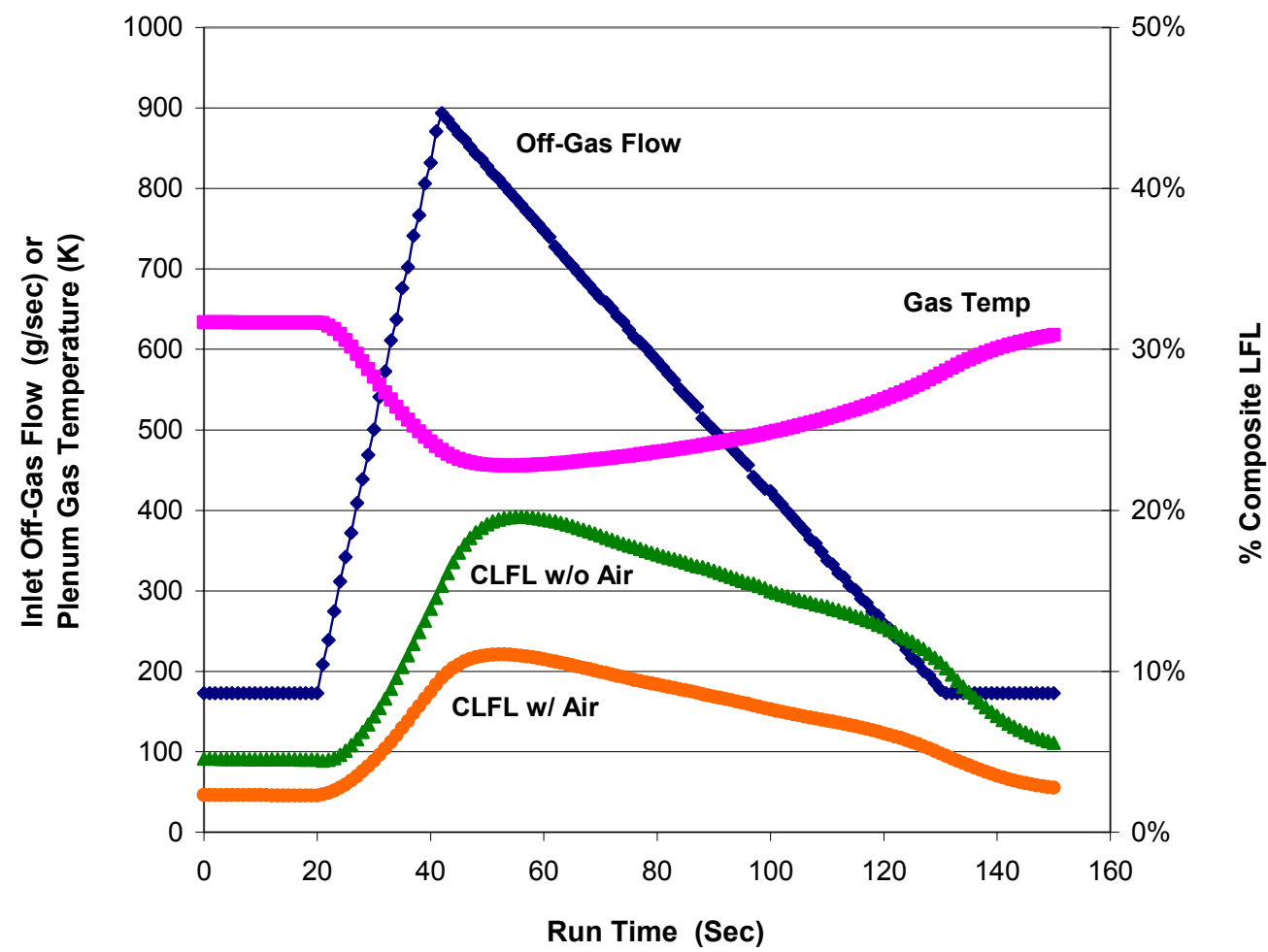

Figure 2-30. 7X/3X Offgas Surge with 1X Nominal Sugar @ $400{ }^{\circ} \mathrm{C}$ Plenum Temperature

\subsubsection{Stage 2 Case Study}

Based on the results of Stage 1 case study, a total of 19 additional cases were run to further focus on the sugar levels between $1 \mathrm{X}$ and $2 \mathrm{X}$ nominal under the following air purge combinations:

1. Air inleakage OFF; Control air OFF

2. Air inleakage $\mathbf{O N}$; Control air $\mathbf{O F F}$

3. Air inleakage $\mathbf{O N}$; Control air $\mathbf{O N}$

Since the baseline melter air inleakage and melter pressure control air flows are both set at $300 \mathrm{scfm}$, the $4^{\text {th }}$ combination of air inleakage OFF and control air ON would yield nearly the same results as the $2^{\text {nd }}$ combination so it was not included. The melter plenum temperature was set either at the nominal $400{ }^{\circ} \mathrm{C}$ or the minimum value of $300{ }^{\circ} \mathrm{C}$. 
The resulting flammability predictions for those 19 cases are tabulated in Table 2-13. Also shown are the five Stage 1 cases for comparison purposes. The key result was that at $1 \mathrm{X}$ nominal sugar, the potential for offgas flammability was found to be remote in all cases considered, regardless of operating mode, plenum temperature and air purge variations. At $2 \mathrm{X}$ nominal sugar, however, the peak flammability potential of the SBS vent during a $7 \mathrm{X} / 3 \mathrm{X}$ offgas surge was predicted to be $55 \%$ of the CLFL under the least conservative operating scenario of including both melter air inleakage and pressure control air, i.e., the $3^{\text {rd }}$ air purge combination at the higher plenum temperature of $400{ }^{\circ} \mathrm{C}$ (Case 32). Furthermore, when the sugar level was doubled from $1 \mathrm{X}$ to $2 \mathrm{X}$ nominal during $7 \mathrm{X} / 3 \mathrm{X}$ offgas surge, the resulting flammability potential of the SBS vent was increased by a factor of at least 6.5 at all melter plenum temperatures and air purge modes assumed (Case 27 vs. 33). These results clearly show how strong an impact the sugar over-batching has on the offgas flammability.

During normal operation with no offgas surges, the plenum temperature showed a strong impact on the offgas flammability. When the melter plenum temperature was lowered from 400 to $300{ }^{\circ} \mathrm{C}$ at $2 \mathrm{X}$ nominal sugar under the most conservative air purge scenario of excluding both melter air inleakage and pressure control air, the flammability potential of the SBS vent was predicted to increase by $142 \%$ to $47 \%$ of the CLFL (Case 21 vs. 23). However, the melter plenum temperatures between 300 and $400{ }^{\circ} \mathrm{C}$ showed little or no impact on the offgas flammability in all offgas surge cases considered, since the baseline value of $400{ }^{\circ} \mathrm{C}$ assumed in this work was already low enough that practically there was no difference between predicted offgas flammability potentials at 300 and $400{ }^{\circ} \mathrm{C}$ during the offgas surge.

When $100 \%$ of the baseline air inleakage rate of $300 \mathrm{scfm}$ was included in the calculation, the resulting flammability potential of the SBS vent was shown to decrease by $40-50 \%$ regardless of the operating mode compared to those cases where no air inleakage was allowed. On the other hand, when $100 \%$ of the baseline control air flow set at $300 \mathrm{scfm}$ was included in the calculation in addition to the $300 \mathrm{scfm}$ of melter air inleakage, the resulting flammability potential of the SBS vent was shown to decrease by an additional $17 \%$ regardless of the operating mode.

As for the relative impact of offgas surges, the flammability potential of the SBS vent is shown to increase by a factor of 2.6 (Case 18 vs. 27) to 6.5 (Case 21 vs. 30), when the operating mode was changed from normal to $7 \mathrm{X} / 3 \mathrm{X}$ offgas surge under all melter plenum temperatures and air purge modes assumed. This result shows that the $7 \mathrm{X} / 3 \mathrm{X}$ offgas surge has a somewhat lower impact on the offgas flammability than the sugar level. 
WSRC-TR-2003-00285, REVISION 0

SRT-RPP-2003-00130, REVISION 0

Table 2-13. Results of Stage 2 Case Study for LAW Melter Offgas Flammability Assessment

\begin{tabular}{|c|c|c|c|c|c|c|c|c|}
\hline $\begin{array}{c}\text { Case } \\
\#\end{array}$ & $\begin{array}{c}\text { Offgas } \\
\text { Nominal }\end{array}$ & $\begin{array}{c}\text { Sugar } \\
\text { Level } \\
\mathbf{X} \\
\text { Nominal }\end{array}$ & $\begin{array}{c}\text { Melter } \\
\text { Plenum } \\
\text { Temp } \\
\left(\mathbf{C}^{\mathbf{C}}\right)\end{array}$ & $\begin{array}{c}\text { Melter } \\
\text { Air } \\
\text { Inleakage } \\
\text { (scfm) }\end{array}$ & $\begin{array}{c}\text { Fixed } \\
\text { Air } \\
\text { Purges } \\
\text { (scfm) }\end{array}$ & $\begin{array}{c}\text { Film } \\
\text { Cooler } \\
\text { Air } \\
(\mathbf{s c f m})\end{array}$ & $\begin{array}{c}\text { Pressure } \\
\text { Control } \\
\text { Air } \\
\text { (scfm) }\end{array}$ & $\begin{array}{c}\text { Flammability } \\
\text { Potential of } \\
\text { SBS Vent } \\
\text { (\% CLFL) }\end{array}$ \\
\hline 1 & $1 / 1$ & 1 & 400 & 0 & 101 & 161 & 0 & 4.6 \\
\hline 2 & $1 / 1$ & 1 & 400 & 300 & 101 & 161 & 0 & 2.3 \\
\hline 17 & $1 / 1$ & 1 & 400 & 300 & 101 & 161 & 300 & 1.5 \\
\hline 18 & $1 / 1$ & 1 & 300 & 0 & 101 & 161 & 0 & 7.5 \\
\hline 19 & $1 / 1$ & 1 & 300 & 300 & 101 & 161 & 0 & 3.8 \\
\hline 20 & $1 / 1$ & 1 & 300 & 300 & 101 & 161 & 300 & 2.5 \\
\hline 21 & $1 / 1$ & 2 & 400 & 0 & 139 & 161 & 0 & 19.3 \\
\hline 8 & $1 / 1$ & 2 & 400 & 300 & 101 & 161 & 0 & 10.8 \\
\hline 22 & $1 / 1$ & 2 & 400 & 300 & 101 & 161 & 300 & 7.2 \\
\hline 23 & $1 / 1$ & 2 & 300 & 0 & 139 & 161 & 0 & 46.8 \\
\hline 24 & $1 / 1$ & 2 & 300 & 300 & 101 & 161 & 0 & 26.7 \\
\hline 25 & $1 / 1$ & 2 & 300 & 300 & 101 & 161 & 300 & 17.9 \\
\hline 15 & $7 / 3$ & 1 & 400 & 0 & 101 & 161 & 0 & 19.6 \\
\hline 16 & $7 / 3$ & 1 & 400 & 300 & 101 & 161 & 0 & 11.0 \\
\hline 26 & $7 / 3$ & 1 & 400 & 300 & 101 & 161 & 300 & 7.7 \\
\hline 27 & $7 / 3$ & 1 & 300 & 0 & 101 & 161 & 0 & 19.6 \\
\hline 28 & $7 / 3$ & 1 & 300 & 300 & 101 & 161 & 0 & 11.1 \\
\hline 29 & $7 / 3$ & 1 & 300 & 300 & 101 & 161 & 300 & 7.8 \\
\hline 30 & $7 / 3$ & 2 & 400 & 0 & 139 & 161 & 0 & 126.5 \\
\hline 31 & $7 / 3$ & 2 & 400 & 300 & 101 & 161 & 0 & 76.4 \\
\hline 32 & $7 / 3$ & 2 & 400 & 300 & 101 & 161 & 300 & 54.9 \\
\hline 33 & $7 / 3$ & 2 & 300 & 0 & 139 & 161 & 0 & 126.7 \\
\hline 34 & $7 / 3$ & 2 & 300 & 300 & 101 & 161 & 0 & 76.7 \\
\hline 35 & $7 / 3$ & 2 & 300 & 300 & 101 & 161 & 300 & 55.3 \\
\hline & & & & & & & & \\
\hline
\end{tabular}

\subsubsection{Stage 3 Case Study}

A recent offgas dynamics simulation study showed that the melter air inleakage rate would decrease to the minimum $39 \%$ of the baseline value at the peak of a 10X steam surge [Smith, 2002]. Based on this result, $117 \mathrm{scfm}$ of melter air inleakage was allowed during the $7 \mathrm{X} / 3 \mathrm{X}$ offgas surge simulation, and the resulting flammability potential of the SBS vent at 1.12X nominal sugar was found to peak at $25 \%$ of the CLFL during the surge when the pressure control air was not included (Case 52 in Table 2-14).

If $100 \%$ of the baseline melter air inleakage rate of $300 \mathrm{scfm}$ were to be credited for as part of the combustion and dilution air, the flammability potential of the SBS vent would decrease to $19 \%$ of the CLFL at the peak of the $7 \mathrm{X} / 3 \mathrm{X}$ offgas surges (Case 53). If no melter air inleakage were to be credited for as part of the combustion and dilution air, the flammability potential of the SBS vent would increase to $33 \%$ of the CLFL at the peak of the $7 \mathrm{X} / 3 \mathrm{X}$ offgas surges (Case 51). 
Furthermore, the maximum allowable sugar level during normal operation was shown to be determined by whether a given melter air purge is adequate to satisfy the minimum excess combustion air requirement and not by the offgas flammability potential. For example, the maximum allowable sugar level to satisfy the minimum $20 \%$ excess combustion air requirement without taking credit for the melter air inleakage was calculated to be $1.8 \mathrm{X}$ nominal, while the flammability potential of the SBS vent with the resulting feed containing $80 \%$ over-batched sugar was $19 \%$ of the CLFL (Case 5 in Table 2-12).

Under the offgas surge conditions, however, the maximum allowable sugar level was shown to be determined largely by the offgas flammability potential. For example, even with 117 scfm of melter air inleakage being credited for as part of the combustion and dilution air, it would take only $1.12 \mathrm{X}$ nominal sugar for the SBS vent to reach $25 \%$ of the CLFL at the peak of the $7 \mathrm{X} / 3 \mathrm{X}$ offgas surges.

Table 2-14. Results of Stage 3 Case Study for LAW Melter Offgas Flammability Assessment

\begin{tabular}{|c|c|c|c|c|c|c|c|c|}
\hline $\begin{array}{c}\text { Case } \\
\#\end{array}$ & $\begin{array}{c}\text { Offgas } \\
\text { Surges X } \\
\text { Nominal }\end{array}$ & $\begin{array}{c}\text { Sugar } \\
\text { Level } \\
X \\
\text { Nominal }\end{array}$ & $\begin{array}{c}\text { Melter } \\
\text { Plenum } \\
\text { Temp } \\
\left({ }^{\circ} \mathrm{C}\right)\end{array}$ & $\begin{array}{c}\text { Melter Air } \\
\text { Inleakage } \\
\text { (scfm) }\end{array}$ & $\begin{array}{c}\text { Fixed } \\
\text { Air } \\
\text { Purges } \\
\text { (scfm) }\end{array}$ & $\begin{array}{l}\text { Film } \\
\text { Cooler } \\
\text { Air } \\
\text { (scfm) }\end{array}$ & $\begin{array}{c}\text { Pressure } \\
\text { Control } \\
\text { Air } \\
\text { (scfm) }\end{array}$ & $\begin{array}{c}\text { Flammability } \\
\text { Potential of } \\
\text { SBS Vent } \\
\text { (\% CLFL) }\end{array}$ \\
\hline 36 & $1 / 1$ & 1.2 & 300 & 0 & 101 & 161 & 0 & 15.9 \\
\hline 37 & $1 / 1$ & 1.2 & 300 & 117 & 101 & 161 & 0 & 10.9 \\
\hline 38 & $1 / 1$ & 1.2 & 300 & 300 & 101 & 161 & 0 & 8.0 \\
\hline 39 & $1 / 1$ & 1.15 & 300 & 0 & 101 & 161 & 0 & 13.8 \\
\hline 40 & $1 / 1$ & 1.15 & 300 & 117 & 101 & 161 & 0 & 9.5 \\
\hline 41 & $1 / 1$ & 1.15 & 300 & 300 & 101 & 161 & 0 & 7.0 \\
\hline 42 & $1 / 1$ & 1.12 & 300 & 0 & 101 & 161 & 0 & 12.5 \\
\hline 43 & $1 / 1$ & 1.12 & 300 & 117 & 101 & 161 & 0 & 8.6 \\
\hline 44 & $1 / 1$ & 1.12 & 300 & 300 & 101 & 161 & 0 & 6.3 \\
\hline 45 & $7 / 3$ & 1.2 & 300 & 0 & 101 & 161 & 0 & 43.6 \\
\hline 46 & $7 / 3$ & 1.2 & 300 & 117 & 101 & 161 & 0 & 33.3 \\
\hline 47 & $7 / 3$ & 1.2 & 300 & 300 & 101 & 161 & 0 & 24.8 \\
\hline 48 & $7 / 3$ & 1.15 & 300 & 0 & 101 & 161 & 0 & 37.6 \\
\hline 49 & $7 / 3$ & 1.15 & 300 & 117 & 101 & 161 & 0 & 28.6 \\
\hline 50 & $7 / 3$ & 1.15 & 300 & 300 & 101 & 161 & 0 & 21.3 \\
\hline 51 & $7 / 3$ & 1.12 & 300 & 0 & 101 & 161 & 0 & 33.7 \\
\hline 52 & $7 / 3$ & 1.12 & 300 & 117 & 101 & 161 & 0 & 25.4 \\
\hline 53 & $7 / 3$ & 1.12 & 300 & 300 & 101 & 161 & 0 & 19.0 \\
\hline
\end{tabular}




\subsection{CONCLUSIONS}

Available $\mathrm{H}_{2}$ data were never enough to claim that the validation efforts made in this work were sufficient. To overcome this shortcoming, several layers of conservatism have been intentionally built into both LAW melter cold cap and plenum combustion models. They include tailoring the multistage structure of the cold cap model such that the predicted calcine gas compositions would be bounding, particularly with respect to the $\mathrm{H}_{2}$ and $\mathrm{CO}$ data. Furthermore, despite the fact that methane is just as flammable as hydrogen, its combustion in the plenum was arbitrarily suppressed completely so that predicted offgas composition exiting the melter would be rendered more flammable. In the end, however, it was the excellent overall agreements shown between model predictions and measured data on both flammable and non-flammable gases that seem to support the use of these models as a tool for assessing the flammability potential.

Based on the results of model runs discussed so far, the following conclusions can be made:

- With the baseline fixed melter air purge of $101 \mathrm{scfm}$, the maximum tolerable level of sugar in terms of satisfying the minimum $20 \%$ excess combustion air is $1.8 \mathrm{X}$ nominal and the predicted flammability potential of the SBS vent is $19 \%$ of the CLFL for normal operation.

- With the total melter air purge of $401 \mathrm{scfm}$, including $300 \mathrm{scfm}$ air inleakage, the maximum tolerable level of sugar in terms of satisfying the minimum $20 \%$ excess combustion air is higher than $4 \mathrm{X}$ nominal and the predicted flammability potential of the SBS vent at $4 \mathrm{X}$ nominal sugar is $49 \%$ of the CLFL for normal operation.

- Offgas flammability potential is found to be remote in all 1X nominal sugar cases considered, regardless of operating mode, plenum temperature and air purges.

- The melter plenum temperature has a strong impact on the offgas flammability for normal operation but has little impact during $7 \mathrm{X} / 3 \mathrm{X}$ offgas surge.

- With 117 scfm melter air inleakage but no pressure control air, the peak flammability potential of the SBS vent at $1.12 \mathrm{X}$ nominal sugar is $25 \%$ of the CLFL during the $7 \mathrm{X} / 3 \mathrm{X}$ offgas surge.

- Under the operating scenarios considered in this work, the order of decreasing impact on the offgas flammability is sugar level, offgas surge, air purge and plenum temperature. 


\subsection{RECOMMENDED FUTURE WORK}

If possible, additional validation efforts need be made to increase the confidence level of each model. For that, new offgas data, particularly $\mathrm{H}_{2}$, must be collected under carefully controlled conditions.

Other studies have shown that inerts can significantly increase the mixture LFL [Briesch, 2000]. Additional study is recommended to determine the effects of inert gases, particularly $\mathrm{CO}_{2}$ and $\mathrm{H}_{2} \mathrm{O}$, on the mixture LFL of the LAW melter off-gas and its flammability potential expressed in terms of \%CLFL. 
WSRC-TR-2003-00285, REVISION 0

SRT-RPP-2003-00130, REVISION 0

This page intentionally left blank. 
WSRC-TR-2003-00285, REVISION 0

SRT-RPP-2003-00130, REVISION 0

\subsection{REFERENCES}

Briesch, E. M., "NEC Group Classification of Mixtures," Presented at AIChE $34^{\text {th }}$ Loss Prevention Symposium, March 2000, Atlanta, GA, Underwriters Laboratories, Inc., 1999.

Choi, A. S., 2000, "Validation of DWPF Melter Offgas Combustion Model," WSRC-TR2000-00100, Westinghouse Savannah River Co., Aiken, SC.

Choi, A. S., 2002, “Task Technical and Quality Assurance Plan for LAW Melter Cold Cap and Offgas Flammability Modeling," WSRC-TR-2002-00234, Rev. 0, Westinghouse Savannah River Co., Aiken, SC.

Choi, A. S., and Iverson, D. C., 1996, "Method of Offgas Flammability Control for DWPF Melter Offgas System at Savannah River Site," Proceedings, International Topical Meeting on Nuclear and Hazardous Waste Management SPECTRUM '96, Seattle, WA.

Choi, A. S., et al., 1988, "Summary of Campaigns SGM-9 and SGM-10 of the DWPF Scale Glass Melter,” DPST-88-626, du Pont de Nemours \& Co., Aiken, SC.

Lide, D. R., Editor, CRC Handbook of Chemistry and Physics, 83 ${ }^{\text {rd }}$ Ed., CRC Press, 2002.

Kelly, Jr., Sam, 2002, "Low Activity Waste (LAW) and High Level Waste (HLW) Melter and Offgas Chemistry Modeling," 24590-WTP-TSP-RT-02-003, Rev. 0, Washington Group International, Richland, WA.

Matlack, K. S., Gong, W., Bardakci, T., D’Angelo, N., and Pegg, I. L., 2002a, “Integrated Offgas System Tests on the DM1200 Melter with RPP-WTP LAW Sub-Envelope C1 Simulants," VSL-02R8800-1, Rev. 0, Vitreous State Laboratory, Washington, DC.

Matlack, K. S., Gong, W., Bardakci, T., D’Angelo, N., and Pegg, I. L., 2002b, “Integrated Offgas System Tests on the DM1200 Melter with RPP-WTP LAW Sub-Envelope A1 Simulants," VSL-02R8800-2, Rev. 0, Vitreous State Laboratory, Washington, DC.

Matlack, K. S., Gong W., Bardakci, T., D’Angelo, N., and Pegg, I. L., 2003a, “Integrated Offgas System Tests on the DM1200 Melter with RPP-WTP LAW Sub-Envelope B1 Simulants," VSL-03R3851-1, Rev. A, Vitreous State Laboratory, Washington, DC.

Matlack, K. S. and Pegg, I. L., 2003b, "Plenum Gas Sampling During LAW DM10 and DM1200 Tests in Support of Flammability Models," VSL-03S3850-1, Rev. 0, Vitreous State Laboratory, Washington, DC.

Matlack, K. S., Weiliang, G., and Pegg, I. L., 2003c, "Compositional Variation Tests on DuraMelter 100 with LAW Sub-Envelope A3 Feed in Support of the LAW Pilot Melter," VSL-01R62N0-1, Rev. 2, Vitreous State Laboratory, Washington, DC. 
Matlack, K. S., Bardakci, T., Schatz, T. R., and Pegg, I. L., 2003d, "Plenum Gas Sampling During LAW Sub-Envelopes A1 and C2 DM10 Tests in Support of Flammability Models," VSL-03S3850-2, Rev 0, Vitreous State Laboratory, Washington, DC.

NFPA 69, Standard on Explosion Prevention Systems, National Fire Protection Association, 470 Atlantic Ave., Boston, MA (1992).

Pelton, A. D. and Wu, P., 1999, "Thermodynamic modeling in glass-forming melts", Journal of Non-Crystalline Solids, 253, pp. 178-191.

Pelton, A. D., Eriksson, G., and Romero-Serrano, A., 1993, "Calculation of sulfide capacities of multicomponent slags", Metallurgical Transactions B, 24B, pp. 817-825.

Rossell, S., 2003, “Melter Air Additions,” 24590-HLW-M4C-HOP-00004, Rev. C, Bechtel National, Richland, WA.

Smail, T. R., 2003a, "WTP Melter Cold Cap Modeling Software Test Documentation," G-STP-A-00004, Westinghouse Savannah River Co., Aiken, SC.

Smail, T. R., 2003b, "WTP Melter Offgas Flammability Modeling Software Test Documentation,” G-STP-A-00005, Westinghouse Savannah River Co., Aiken, SC.

Smith, F. G., 2002, "Case Studies with the Hanford WTP LAW Melter Offgas/Vessel Ventilation Dynamic Pressure and Control Model (U)," WSRC-TR-2002-00371, Rev. 0, Westinghouse Savannah River Co., Aiken, SC.

\section{Software Documentation}

FactSage $^{\mathrm{TM}}$, 2002, http://www.factsage.com/ , ThermFact, Ltd., Mount Royal, Quebec, Canada.

FactSage 5.0, 2002, "Workshop Course Notes."

Chem/Sage Handbook, Chapter 12, "Introduction to the Reactor Model Module."

CHEMKIN $^{\circledR}$ Collection, 2002, http://www.reactiondesign.com//, Reaction Design, San Diego, CA. 


\section{APPENDIX A. FACT/SAGE CHEMICAL SPECIES}

\section{Ideal Gases (20)}

$\mathrm{H} 2, \mathrm{CH} 4, \mathrm{NH} 3, \mathrm{HCN}, \mathrm{O} 2, \mathrm{H} 2 \mathrm{O}, \mathrm{CO}, \mathrm{CO} 2, \mathrm{NO}, \mathrm{N} 2 \mathrm{O}, \mathrm{NO} 2, \mathrm{HONO}$,

$\mathrm{HONO} 2, \mathrm{~F} 2, \mathrm{HF}, \mathrm{NaBO} 2, \mathrm{SO} 2, \mathrm{Cl} 2, \mathrm{HCl}, \mathrm{CH} 3 \mathrm{Cl}, \mathrm{C} 6 \mathrm{ClH} 5$

\section{Slag A (24)}

$\mathrm{MgO}, \mathrm{FeO},(\mathrm{Na} 2 \mathrm{O}): 2.000, \mathrm{SiO} 2, \mathrm{TiO} 2,(\mathrm{Ti} 2 \mathrm{O} 3): 2.000, \mathrm{CaO}$,

(A12O3):2.000, (K2O):2.000, MgS, CaS, FeS,

(Na2S):2.000, (K2S):2.000, NaF, KF, CaF2, MgF2,

$\mathrm{NaCl}, \mathrm{KCl}, \mathrm{CaCl} 2, \mathrm{MgCl} 2, \mathrm{FeCl} 2, \mathrm{FeF} 2$

\section{$\underline{\text { Slag C (22) }}$}

$\mathrm{MgO},(\mathrm{Na} 2 \mathrm{O}): 2.000, \mathrm{SiO} 2, \mathrm{CaO},(\mathrm{Al} 2 \mathrm{O} 3): 2.000, \mathrm{MgS}$,

$\mathrm{CaS},(\mathrm{Na} 2 \mathrm{~S}): 2.000,(\mathrm{~B} 2 \mathrm{O} 3): 2.000,(\mathrm{Na} 2 \mathrm{SO} 4): 2.000, \mathrm{CaSO} 4$,

$\mathrm{MgSO} 4, \mathrm{NaF}, \mathrm{CaF} 2, \mathrm{MgF} 2, \mathrm{NaCl}, \mathrm{CaCl} 2, \mathrm{MgCl} 2$,

(H2O):2.000, $\mathrm{NaOH}, \mathrm{Ca}(\mathrm{OH}) 2, \mathrm{Mg}(\mathrm{OH}) 2$

\section{Spinel (20)}

Fe3O4[2-], Fe3O4[1-], Fe3O4, Fe3O4[1+], Fe1O4[6-],

Fe1O4[5-], Zn1Fe2O4[2-], Zn1Fe2O4, Zn3O4[2-], Zn1O4[6-],

Fe1Zn2O4[2-], Fe1Zn2O4[1-], Fe1Al2O4, Zn1A12O4, Fe1Al2O4[1+],

$\mathrm{Al3O} 4[1+], \mathrm{Al1Fe} 2 \mathrm{O} 4[1-], \mathrm{Al1Zn2O4[1-],} \mathrm{Al1Fe2O4[1+],} \mathrm{Al1O4[5-]}$

\section{Liquid Phase (5)}

CH3NC_acetonit, $\mathrm{CH} 3 \mathrm{OH}, \mathrm{HCOOH}, \mathrm{CH} 3 \mathrm{COOH}, \mathrm{H} 2 \mathrm{O}$

\section{Condensed Phase (42)}

C_graphite, H3BO3, Na2O, NaOH, NaBO2, NaB3O5, Na2B4O7, $\mathrm{Na} 2 \mathrm{CO} 3, \mathrm{NaNO} 2$ alpha, $\mathrm{NaNO} 3, \mathrm{NaF}$ _villiauite (nacl_salt), $\mathrm{Al}(\mathrm{OH}) 3$, $\mathrm{Al}(\mathrm{NO} 3) 3(\mathrm{H} 2 \mathrm{O}) 6, \mathrm{SiO} 2$ quartz, $\mathrm{Mg} 2 \mathrm{SiO} 4$ forsterite, $\mathrm{A} 12 \mathrm{SiO} 5$ andalusite, $\mathrm{NaAlSiO} 4$ nepheline-b, NaAlSiO4_nepheline-c, NaAlSiO4_carnegieite, $\mathrm{NaA1Si3O} \overline{8}$ low, NaA1Si3O8_high, Na2SO4, Na3F(SO4), $\overline{\mathrm{NaCl}}$ halite (rock salt), $\mathrm{KOH}, \mathrm{KA} 1 \overline{\mathrm{Si}} 2 \mathrm{O} 6$ leucite(rhf), $\mathrm{CaSiO} 3$ wollastonite, $\mathrm{Na} 2 \mathrm{Ca} 2 \mathrm{Si} 3 \mathrm{O} 9$, $\mathrm{Na} 2 \mathrm{Ca} 3 \mathrm{Si} 6 \mathrm{O} 16, \overline{\mathrm{TiO}} 2$ rutile, $(\mathrm{Na} 2 \mathrm{O})(\overline{\mathrm{TiO}} 2) 3,(\mathrm{Na} 2 \mathrm{O})(\mathrm{TiO} 2) 6$, $\mathrm{Fe} 2 \mathrm{O} 3$ _hematite, $\mathrm{ZnO}$ zincite, $\mathrm{Zn} 2 \mathrm{SiO} 4$ willemite, $(\mathrm{ZnO}) 2(\mathrm{TiO} 2)$, $\mathrm{ZrO} 2$ monoclinic, $\mathrm{ZrO} 2$ _tetragonal, $\mathrm{ZrO} 2$ _cubic, $\mathrm{ZrSiO} 4$ zircon, ZrTiO4, Ti2ZrO6 
WSRC-TR-2003-00285, REVISION 0

SRT-RPP-2003-00130, REVISION 0

This page intentionally left blank. 
WSRC-TR-2003-00285, REVISION 0

SRT-RPP-2003-00130, REVISION 0

\section{APPENDIX B. COMPOSITION OF MODEL FEED STREAMS}

\begin{tabular}{|c|c|c|c|c|c|c|c|}
\hline \multirow{3}{*}{$\begin{array}{l}\text { Chemical } \\
\text { Species }\end{array}$} & \multicolumn{7}{|c|}{ Model Feed Rate Moles/hr } \\
\hline & \multicolumn{3}{|c|}{ DM10 } & \multirow{2}{*}{$\frac{\text { DM100 }}{\text { A3 }}$} & \multicolumn{3}{|c|}{ DM1200 } \\
\hline & A1 & A2 & C2 & & A1 & B1 & C1 \\
\hline $\mathrm{H}_{2} \mathrm{O}$ & 112.180 & 210.895 & 120.176 & 234.504 & 2889.76 & 2528.78 & 2822.73 \\
\hline $\begin{array}{l}\mathrm{Al}\left(\mathrm{NO}_{3}\right)_{3} \\
\cdot 6 \mathrm{H}_{2} \mathrm{O}\end{array}$ & 1.917 & 1.827 & 0.575 & & 45.65 & 10.62 & 9.32 \\
\hline $\mathrm{Al}(\mathrm{OH})_{3}$ & 0.986 & & & 3.340 & 32.91 & & \\
\hline $\mathrm{KOH}$ & 0.333 & 5.665 & 0.100 & 0.359 & 9.08 & 3.28 & 1.58 \\
\hline $\mathrm{NaOH}$ & 16.721 & 22.761 & 6.672 & 9.981 & 413.92 & 53.33 & 147.42 \\
\hline $\mathrm{NaCl}$ & 1.183 & 0.841 & 0.109 & 0.611 & 14.24 & & 1.86 \\
\hline $\mathrm{NaF}$ & & 1.293 & 0.098 & 0.087 & 1.17 & 2.71 & 6.23 \\
\hline $\mathrm{Na}_{2} \mathrm{SO}_{4}$ & 0.084 & 0.351 & 0.203 & 0.359 & 2.74 & 6.45 & 3.90 \\
\hline $\mathrm{NaNO}_{2}$ & 5.249 & 6.468 & 1.799 & 7.042 & 140.98 & 38.91 & 47.96 \\
\hline $\mathrm{NaNO}_{3}$ & & 9.562 & 1.743 & 7.423 & & & 87.73 \\
\hline $\mathrm{Na}_{2} \mathrm{O}$ & & & 4.354 & 7.718 & 14.48 & 131.77 & 112.80 \\
\hline $\mathrm{Al}_{2} \mathrm{SiO}_{5}$ & 0.625 & 3.159 & 2.099 & 2.580 & 19.07 & 50.43 & 52.18 \\
\hline $\mathrm{H}_{3} \mathrm{BO}_{3}$ & 9.322 & 20.084 & 10.268 & 19.813 & 240.12 & 236.85 & 243.39 \\
\hline $\mathrm{CaSiO}_{3}$ & 1.277 & 2.634 & 4.649 & 6.499 & 32.67 & 98.66 & 75.62 \\
\hline $\mathrm{Fe}_{2} \mathrm{O}_{3}$ & 1.450 & 2.314 & 0.863 & 2.081 & 37.22 & 23.49 & 25.85 \\
\hline $\mathrm{Mg}_{2} \mathrm{SiO}_{4}$ & 1.046 & 1.509 & 0.774 & 1.456 & 26.86 & 35.44 & 18.44 \\
\hline $\mathrm{SiO}_{2}$ & 22.143 & 41.840 & 18.215 & 38.966 & 565.62 & 433.95 & 459.47 \\
\hline $\mathrm{TiO}_{2}$ & 0.918 & 1.847 & 0.508 & 0.977 & 23.56 & 14.57 & 12.22 \\
\hline $\mathrm{ZnO}$ & 1.281 & 2.528 & 1.710 & 2.477 & 32.92 & 47.55 & 30.81 \\
\hline $\mathrm{ZrSiO}_{4}$ & 0.858 & 1.706 & 0.853 & 1.613 & 22.08 & 20.63 & 20.20 \\
\hline $\mathrm{HCOOH}$ & 0.236 & 0.445 & 3.166 & 0.239 & 10.93 & 1.63 & 44.58 \\
\hline $\mathrm{CH}_{3} \mathrm{COOH}$ & 3.794 & 7.318 & 0.537 & 19.589 & 85.92 & 23.36 & 26.64 \\
\hline $\mathrm{CH}_{4} \mathrm{O}$ & & & 0.127 & 0.034 & 1.57 & & 1.70 \\
\hline $\mathrm{CH}_{3} \mathrm{CN}$ & & & 0.470 & 0.077 & 3.94 & & 6.71 \\
\hline C & 0.648 & 1.251 & 0.431 & 3.599 & 17.27 & 4.25 & 13.47 \\
\hline $\mathrm{CO}_{2}$ & 0.000 & 0.193 & 5.039 & 7.909 & 15.04 & 133.40 & 114.92 \\
\hline
\end{tabular}


WSRC-TR-2003-00285, REVISION 0

SRT-RPP-2003-00130, REVISION 0

This page intentionally left blank. 
WSRC-TR-2003-00285, REVISION 0

SRT-RPP-2003-00130, REVISION 0

\section{APPENDIX C. BASELINE CALCINE GAS COMPOSITIONS FOR HIGHER SUGAR RUNS}

Table C-1. Predicted vs. Adjusted Envelope A1 Calcine Gas Compositions (2X Nominal Sugar).

\begin{tabular}{|c|c|c|c|c|}
\hline & $\begin{array}{r}\text { Cold Cap Model } \\
\text { Output }\end{array}$ & $\begin{array}{l}\text { Adjusted Input to } \\
\text { Combustion Model }\end{array}$ & $\begin{array}{r}\text { DM10 A1 Data } \\
\text { [Matlack, 2003d] }\end{array}$ & Comment on Data \\
\hline & (mole fraction) & (mole fraction) & & \\
\hline calcine $\mathrm{H} 2 \mathrm{O}$ & 0.60104 & 0.62500 & & \\
\hline $\mathrm{CO}$ & 0.01512 & 0.01357 & & \\
\hline $\mathrm{CO}_{2}$ & 0.21704 & 0.19472 & & \\
\hline $\mathrm{H}_{2}$ & 0.04345 & 0.03898 & & \\
\hline NO & 0.00046 & 0.02061 & & \\
\hline $\mathrm{N}_{2} \mathrm{O}$ & 0.05585 & 0.00657 & & \\
\hline $\mathrm{NO}_{2}$ & 0.00000 & 0.00189 & & \\
\hline $\mathrm{NH}_{3}$ & 0.05567 & 0.04995 & & \\
\hline $\mathrm{O}_{2}$ & 0.00000 & 0.00978 & & \\
\hline $\mathrm{N}_{2}$ & 0.00000 & 0.03249 & & \\
\hline $\mathrm{CH}_{4}$ & 0.00720 & 0.00646 & & \\
\hline Total & 0.99582 & 1.00000 & & \\
\hline $\mathrm{CO} / \mathrm{CO}_{2}$ & 0.070 & 0.070 & 0.031 & peak DM10 A1 \\
\hline $\mathrm{H}_{2} /\left(\mathrm{CO}+\mathrm{CO}_{2}\right)$ & 0.187 & 0.187 & 0.027 & $"$ \\
\hline $\mathrm{THC} /\left(\mathrm{CO}+\mathrm{CO}_{2}\right)$ & 0.031 & 0.031 & 0.072 & $"$ \\
\hline $\mathrm{NH}_{3} / \mathrm{NO}_{\mathrm{x}}$ & 0.496 & 1.402 & 0.680 & $"$ \\
\hline $\mathrm{NO}_{\mathbf{x}} /\left(\mathrm{NO}_{3}+\mathrm{NO}_{2}\right)$ & 0.68 & 0.24 & 0.51 & DM100 A3 data \\
\hline $\mathrm{NO} / \mathrm{NO}_{\mathrm{x}}$ & 0.008 & 0.71 & 0.78 & average DM10 A1 \\
\hline $\mathrm{N}_{2} \mathrm{O} / \mathrm{NO}_{\mathrm{x}}$ & 0.992 & 0.07 & 0.14 & $"$ \\
\hline $\mathrm{NO}_{2} / \mathrm{NO}_{\mathrm{x}}$ & 0.000 & 0.23 & 0.08 & $"$ \\
\hline
\end{tabular}


WSRC-TR-2003-00285, REVISION 0

SRT-RPP-2003-00130, REVISION 0

Table C-2. Predicted vs. Adjusted Envelope A1 Calcine Gas Compositions (3X Nominal Sugar)

\begin{tabular}{|c|c|c|c|c|}
\hline & $\begin{array}{r}\text { Cold Cap Model } \\
\text { Output }\end{array}$ & Adjusted Input to & DM10 A1 Data & Comment on Data \\
\hline & (mole fraction) & (mole fraction) & & \\
\hline calcine $\mathrm{H} 2 \mathrm{O}$ & 0.50317 & 0.53897 & & \\
\hline $\mathrm{CO}$ & 0.02437 & 0.02230 & & \\
\hline $\mathrm{CO}_{2}$ & 0.26259 & 0.24035 & & \\
\hline $\mathrm{H}_{2}$ & 0.06076 & 0.05562 & & \\
\hline NO & 0.00019 & 0.01168 & & \\
\hline $\mathrm{N}_{2} \mathrm{O}$ & 0.02714 & 0.00471 & & \\
\hline $\mathrm{NO}_{2}$ & 0.00000 & 0.00061 & & \\
\hline $\mathrm{NH}_{3}$ & 0.09589 & 0.08777 & & \\
\hline $\mathrm{O}_{2}$ & 0.00000 & 0.00370 & & \\
\hline $\mathrm{N}_{2}$ & 0.00000 & 0.01407 & & \\
\hline $\mathrm{CH}_{4}$ & 0.02208 & 0.02021 & & \\
\hline Total & 0.99619 & 1.00000 & & \\
\hline $\mathrm{CO} / \mathrm{CO}_{2}$ & 0.093 & 0.093 & 0.031 & peak DM10 A1 \\
\hline $\mathrm{H}_{2} /\left(\mathrm{CO}+\mathrm{CO}_{2}\right)$ & 0.212 & 0.212 & 0.027 & $"$ \\
\hline $\mathrm{THC} /\left(\mathrm{CO}+\mathrm{CO}_{2}\right)$ & 0.077 & 0.077 & 0.072 & $"$ \\
\hline $\mathrm{NH}_{3} / \mathrm{NO}_{\mathrm{x}}$ & 1.760 & 4.042 & 0.680 & $"$ \\
\hline $\mathrm{NO}_{x} /\left(\mathrm{NO}_{3}+\mathrm{NO}_{2}\right)$ & 0.37 & 0.16 & 0.51 & DM100 A3 data \\
\hline $\mathrm{NO} / \mathrm{NO}_{\mathrm{x}}$ & 0.007 & 0.69 & 0.78 & average DM10 A1 \\
\hline $\mathrm{N}_{2} \mathrm{O} / \mathrm{NO}_{\mathrm{x}}$ & 0.993 & 0.04 & 0.14 & $"$ \\
\hline $\mathrm{NO}_{2} / \mathrm{NO}_{\mathrm{x}}$ & 0.000 & 0.28 & 0.08 & $"$ \\
\hline
\end{tabular}


WSRC-TR-2003-00285, REVISION 0

SRT-RPP-2003-00130, REVISION 0

Table C-3. Predicted vs. Adjusted Envelope A1 Calcine Gas Compositions (4X Nominal Sugar)

\begin{tabular}{|c|c|c|c|c|}
\hline & $\begin{array}{r}\text { Cold Cap Model } \\
\text { Output }\end{array}$ & $\begin{array}{l}\text { Adjusted Input to } \\
\text { Combustion Model }\end{array}$ & $\begin{array}{r}\text { DM10 A1 Data } \\
\text { [Matlack, 2003d] }\end{array}$ & Comment on Data \\
\hline & (mole fraction) & (mole fraction) & & \\
\hline calcine $\mathrm{H} 2 \mathrm{O}$ & 0.41680 & 0.44992 & & \\
\hline $\mathrm{CO}$ & 0.03777 & 0.05018 & & \\
\hline $\mathrm{CO}_{2}$ & 0.29910 & 0.25684 & & \\
\hline $\mathrm{H}_{2}$ & 0.08283 & 0.09911 & & \\
\hline NO & 0.00000 & 0.00816 & & \\
\hline $\mathrm{N}_{2} \mathrm{O}$ & 0.00001 & 0.00366 & & \\
\hline $\mathrm{NO}_{2}$ & 0.00000 & 0.00029 & & \\
\hline $\mathrm{NH}_{3}$ & 0.13486 & 0.10716 & & \\
\hline $\mathrm{O}_{2}$ & 0.00000 & 0.00168 & & \\
\hline $\mathrm{N}_{2}$ & 0.00000 & 0.00000 & & \\
\hline $\mathrm{CH}_{4}$ & 0.02523 & 0.02300 & & \\
\hline Total & 0.99660 & 1.00000 & & \\
\hline $\mathrm{CO} / \mathrm{CO}_{2}$ & 0.126 & 0.195 & 0.031 & peak DM10 A1 \\
\hline $\mathrm{H}_{2} /\left(\mathrm{CO}+\mathrm{CO}_{2}\right)$ & 0.246 & 0.323 & 0.027 & $"$ \\
\hline $\mathrm{THC} /\left(\mathrm{CO}+\mathrm{CO}_{2}\right)$ & 0.075 & 0.075 & 0.075 & $"$ \\
\hline $\mathrm{NH}_{3} / \mathrm{NO}_{\mathrm{x}}$ & 0.013 & 6.799 & 0.680 & $"$ \\
\hline $\mathrm{NO}_{x} /\left(\mathrm{NO}_{3}+\mathrm{NO}_{2}\right)$ & 0.25 & 0.00 & 0.51 & DM100 A3 data \\
\hline $\mathrm{NO} / \mathrm{NO}_{x}$ & 0.000 & 0.67 & 0.78 & average DM10 A1 \\
\hline $\mathrm{N}_{2} \mathrm{O} / \mathrm{NO}_{\mathrm{x}}$ & 0.000 & 0.02 & 0.14 & $"$ \\
\hline $\mathrm{NO}_{2} / \mathrm{NO}_{\mathrm{x}}$ & 0.116 & 0.30 & 0.08 & $"$ \\
\hline
\end{tabular}


WSRC-TR-2003-00285, REVISION 0

SRT-RPP-2003-00130, REVISION 0

This page intentionally left blank. 


\section{APPENDIX D. RELATIVE FLAMMABILITIES OF HC SPECIES}

The flammability data for various $\mathrm{HC}$ and non $\mathrm{HC}$ species are tabulated in the literature [Lide, 2002]. Listed below are the LFLs of some of the most flammable HC species:

\begin{tabular}{|l|c|}
\hline Species & LFL (\%) \\
\hline $\mathrm{CH}_{4}$ & 5.0 \\
\hline $\mathrm{C}_{2} \mathrm{H}_{6}$ & 3.0 \\
\hline $\mathrm{C}_{2} \mathrm{H}_{4}$ & 2.7 \\
\hline $\mathrm{C}_{2} \mathrm{H}_{2}$ & 2.5 \\
\hline $\mathrm{C}_{3} \mathrm{H}_{8}$ & 2.1 \\
\hline $\mathrm{C}_{3} \mathrm{H}_{6}$ & 2.0 \\
\hline $\mathrm{C}_{4} \mathrm{H}_{12}$ & 1.9 \\
\hline $\mathrm{C}_{4} \mathrm{H}_{8}$ (1-Butene) & 1.6 \\
\hline
\end{tabular}

The general trend shown by the data is that as the number of carbons increases, the LFL decreases and, therefore, the gas becomes more flammable. The question is then: what happens to the relative flammability of normal paraffins per unit carbon basis?

Suppose the THC concentration in the offgas was measured to be 1 volume $\%$ in terms of propane equivalents, as reported in the VSL data. Then, the flammability potential due to THC only will be:

$$
\frac{1}{2.1}=0.48 \text { or } 48 \% \text { of the } L F L
$$

If the measured THC concentration is assumed to be all due to methane, the potential flammability then becomes:

$$
\frac{(1)(3)}{5.0}=0.60 \text { or } \quad 60 \% \text { of the LFL }
$$

where the reported THC data is multiplied by the factor of 3, which is the carbon ratio of propane to methane. This simple calculation shows that assuming that the THC data reported in terms of propane equivalents is all due to methane, as was done in this work, would result in $25 \%$ higher flammability potential than the measured value. 
If the measured THC concentration is assumed to be all due to ethane instead of methane, the potential flammability then becomes:

$$
\frac{(1)(1.5)}{3.0}=0.50 \text { or } 50 \% \text { of the } L F L
$$

where the reported THC data is multiplied by the factor of 1.5 , which is the carbon ratio of propane to ethane. Therefore, assuming that the THC data reported in terms of propane equivalents is all due to ethane, would result in nearly the same flammability potential as the measured value.

Likewise, if the measured THC concentration is assumed to be all due to butane, the potential flammability then becomes:

$$
\frac{(1)(0.75)}{1.9}=0.39 \text { or } 39 \% \text { of the LFL }
$$

where the reported THC data is multiplied by the factor of 0.75 , which is the carbon ratio of propane to butane. Therefore, assuming that the THC data reported in terms of propane equivalents is all due to butane would result in a lower flammability potential than the measured value.

The LFL data given above also shows that unsaturated paraffins are more flammable than their saturated counterparts. So, similar calculations were made for unsaturated paraffins, and the results are tabulated below. It is clearly seen that assuming that the THC data reported in terms of propane equivalents is all due to either methane or acetylene would result in the highest flammability potential.

\begin{tabular}{|l|c|}
\hline Species Assumed to Represent THC Data & Calculated Flammability (\% LFL) \\
\hline $\mathrm{CH}_{4}$ & 60 \\
\hline $\mathrm{C}_{2} \mathrm{H}_{6}$ & 50 \\
\hline $\mathrm{C}_{2} \mathrm{H}_{4}$ & 56 \\
\hline $\mathrm{C}_{2} \mathrm{H}_{2}$ & 60 \\
\hline $\mathrm{C}_{3} \mathrm{H}_{8}$ (Basis for VSL Data) & $\mathbf{4 8}$ \\
\hline $\mathrm{C}_{3} \mathrm{H}_{6}$ & 50 \\
\hline $\mathrm{C}_{4} \mathrm{H}_{10}$ (1-Butene) & 39 \\
\hline $\mathrm{C}_{4} \mathrm{H}_{8}$ - & 47 \\
\hline
\end{tabular}




\section{APPENDIX E. CALCULATED COMPOSITIONS OF THE SBS VENT}

(See notes on following page.)

\begin{tabular}{|c|c|c|c|c|c|c|c|c|c|c|c|c|}
\hline Case & $\begin{array}{l}\mathrm{H} 2 \mathrm{O} \\
(\mathrm{vol} \%)\end{array}$ & $\begin{array}{c}\mathrm{CO} \\
(\mathrm{ppmv})\end{array}$ & $\begin{array}{c}\mathrm{CO} 2 \\
(\mathrm{ppmv})\end{array}$ & $\begin{array}{c}\mathrm{H} 2 \\
\text { (ppmv) }\end{array}$ & $\begin{array}{c}\mathrm{NO} \\
(\mathrm{ppmv})\end{array}$ & $\begin{array}{c}\mathrm{N} 2 \mathrm{O} \\
\text { (ppmv) }\end{array}$ & $\begin{array}{c}\mathrm{NO} 2 \\
\text { (ppmv) }\end{array}$ & $\begin{array}{c}\mathrm{NH} 3 \\
\text { (ppmv) }\end{array}$ & $\begin{array}{c}\mathrm{N} 2 \\
\text { (vol\%) }\end{array}$ & $\begin{array}{c}\mathrm{O} 2 \\
\text { (vol\%) }\end{array}$ & $\begin{array}{c}\mathrm{CH} 4 \\
\text { (ppmv) }\end{array}$ & $\begin{array}{c}\text { Total } \\
\text { (ppmv) }\end{array}$ \\
\hline 1 & 7.28 & 1303 & 67787 & 320 & 18653 & 2791 & 13878 & 0 & 65.20 & 16.91 & 1367 & 1000000 \\
\hline 2 & 7.28 & 657 & 34178 & 161 & 9405 & 1407 & 6997 & 0 & 69.19 & 18.18 & 689 & 1000000 \\
\hline 3 & 7.28 & 3594 & 94870 & 2398 & 19771 & 3367 & 12684 & 0 & 64.31 & 14.46 & 2741 & 1000000 \\
\hline 4 & 7.28 & 1821 & 48073 & 1215 & 10018 & 1706 & 6427 & 0 & 68.72 & 16.93 & 1389 & 1000000 \\
\hline 5 & 7.28 & 4384 & 102900 & 2901 & 21097 & 3301 & 13119 & 0 & 63.87 & 13.67 & 4105 & 1000000 \\
\hline 6 & 7.28 & 2226 & 52260 & 1473 & 10714 & 1676 & 6663 & 0 & 68.48 & 16.53 & 2085 & 1000000 \\
\hline 7 & \multicolumn{12}{|c|}{ Results not available since the minimum $20 \%$ excess combustion air requirement was not met. } \\
\hline 8 & 7.28 & 2642 & 57685 & 1968 & 10408 & 1910 & 5996 & 0 & 68.41 & 16.06 & 1878 & 1000000 \\
\hline 9 & \multicolumn{12}{|c|}{ Results not available since the minimum $20 \%$ excess combustion air requirement was not met. } \\
\hline 10 & 7.28 & 4691 & 77039 & 3061 & 14806 & 1470 & 7998 & 0 & 67.09 & 14.09 & 6307 & 1000000 \\
\hline 11 & \multicolumn{12}{|c|}{ Results not available since the minimum $20 \%$ excess combustion air requirement was not met. } \\
\hline 12 & 7.28 & 10698 & 91033 & 5685 & 18015 & 1284 & 9623 & 0 & 66.01 & 12.31 & 7662 & 1000000 \\
\hline 13 & \multicolumn{12}{|c|}{ Results not available since the minimum $20 \%$ excess combustion air requirement was not met. } \\
\hline 14 & 7.28 & 11677 & 93212 & 6115 & 18519 & 1252 & 9878 & 0 & 65.84 & 12.02 & 7875 & 1000000 \\
\hline $15^{*}$ & 7.28 & 4203 & 147121 & 4042 & 77194 & - & - & 0 & 54.35 & 14.81 & 3068 & 1000000 \\
\hline $16^{*}$ & 7.28 & 2345 & 82888 & 2274 & 43506 & - & - & 0 & 62.67 & 16.78 & 1742 & 1000000 \\
\hline 17 & 7.28 & 439 & 22850 & 108 & 6288 & 941 & 4678 & 0 & 70.54 & 18.61 & 461 & 1000000 \\
\hline 18 & 7.28 & 1744 & 67216 & 1336 & 18618 & 2785 & 13852 & 0 & 65.08 & 16.95 & 1364 & 1000000 \\
\hline 19 & 7.28 & 880 & 33922 & 674 & 9396 & 1406 & 6991 & 0 & 69.12 & 18.20 & 688 & 1000000 \\
\hline 20 & 7.28 & 588 & 22686 & 451 & 6284 & 940 & 4675 & 0 & 70.49 & 18.62 & 460 & 1000000 \\
\hline 21 & 7.28 & 4695 & 101002 & 3573 & 18235 & 3346 & 10505 & 0 & 64.75 & 13.50 & 3291 & 1000000 \\
\hline 22 & 7.28 & 1771 & 38672 & 1319 & 6977 & 1280 & 4019 & 0 & 70.00 & 17.19 & 1259 & 1000000 \\
\hline 23 & 7.28 & 6093 & 97699 & 14172 & 17906 & 3286 & 10315 & 0 & 63.58 & 13.87 & 3231 & 1000000 \\
\hline 24 & 7.28 & 3489 & 56216 & 8055 & 10300 & 1890 & 5934 & 0 & 67.70 & 16.25 & 1859 & 1000000 \\
\hline 25 & 7.28 & 2347 & 37816 & 5418 & 6929 & 1271 & 3991 & 0 & 69.52 & 17.30 & 1250 & 1000000 \\
\hline $26^{*}$ & 7.28 & 1635 & 57963 & 1587 & 30425 & - & - & 0 & 65.90 & 17.54 & 1220 & 1000000 \\
\hline $27^{*}$ & 7.28 & 4197 & 146362 & 4051 & 76806 & - & - & 0 & 54.44 & 14.83 & 3054 & 1000000 \\
\hline $28^{*}$ & 7.28 & 2344 & 82342 & 2288 & 43226 & - & - & 0 & 62.73 & 16.79 & 1731 & 1000000 \\
\hline $29^{*}$ & 7.28 & 1637 & 57724 & 1604 & 30306 & - & - & 0 & 65.92 & 17.55 & 1217 & 1000000 \\
\hline $30^{*}$ & 7.28 & 14149 & 205613 & 40739 & 66404 & - & - & 0 & 50.67 & 8.69 & 6683 & 1000000 \\
\hline $31^{*}$ & 7.28 & 8565 & 124621 & 24570 & 40234 & - & - & 0 & 59.65 & 12.87 & 4054 & 1000000 \\
\hline $32^{*}$ & 7.28 & 6181 & 90158 & 17638 & 29097 & - & - & 0 & 63.48 & 14.64 & 2937 & 1000000 \\
\hline $33^{*}$ & 7.28 & 14132 & 204793 & 40778 & 66151 & - & - & 0 & 50.73 & 8.74 & 6658 & 1000000 \\
\hline $34^{*}$ & 7.28 & 8576 & 124316 & 24679 & 40142 & - & - & 0 & 59.66 & 12.89 & 4047 & 1000000 \\
\hline $35^{*}$ & 7.28 & 6188 & 89738 & 17777 & 28972 & - & - & 0 & 63.49 & 14.67 & 2925 & 1000000 \\
\hline 36 & 7.28 & 2704 & 75357 & 4051 & 18923 & 2960 & 13439 & 0 & 64.56 & 16.23 & 1795 & 1000000 \\
\hline 37 & 7.28 & 1903 & 54677 & 2720 & 13716 & 2146 & 9741 & 0 & 66.98 & 17.12 & 1301 & 1000000 \\
\hline 38 & 7.28 & 1369 & 38159 & 2051 & 9582 & 1499 & 6805 & 0 & 68.85 & 17.83 & 909 & 1000000 \\
\hline 39 & 7.28 & 2461 & 73306 & 3364 & 18847 & 2916 & 13544 & 0 & 64.69 & 16.42 & 1686 & 1000000 \\
\hline 40 & 7.28 & 1731 & 53157 & 2258 & 13654 & 2113 & 9812 & 0 & 67.07 & 17.25 & 1222 & 1000000 \\
\hline 41 & 7.28 & 1245 & 37089 & 1702 & 9536 & 1475 & 6853 & 0 & 68.92 & 17.93 & 853 & 1000000 \\
\hline 42 & 7.28 & 2317 & 72080 & 2955 & 18802 & 2890 & 13607 & 0 & 64.77 & 16.52 & 1621 & 1000000 \\
\hline 43 & 7.28 & 1629 & 52250 & 1982 & 13616 & 2093 & 9854 & 0 & 67.13 & 17.33 & 1174 & 1000000 \\
\hline 44 & 7.28 & 1172 & 36450 & 1494 & 9508 & 1461 & 6881 & 0 & 68.96 & 17.98 & 820 & 1000000 \\
\hline $45^{*}$ & 7.28 & 6644 & 161640 & 12122 & 75704 & - & - & 0 & 53.28 & 13.43 & 4003 & 1000000 \\
\hline $46^{*}$ & 7.28 & 5056 & 123551 & 9218 & 57891 & - & - & 0 & 58.06 & 14.78 & 3081 & 1000000 \\
\hline $47^{*}$ & 7.28 & 3762 & 91709 & 6877 & 42952 & - & - & 0 & 61.98 & 15.98 & 2287 & 1000000 \\
\hline $48^{*}$ & 7.28 & 6002 & 158063 & 10172 & 75960 & - & - & 0 & 53.54 & 13.79 & 3673 & 1000000 \\
\hline $49^{*}$ & 7.28 & 4592 & 120679 & 7724 & 57971 & - & - & 0 & 58.28 & 15.06 & 2781 & 1000000 \\
\hline $50 *$ & 7.28 & 3414 & 89517 & 5757 & 43006 & - & - & 0 & 62.16 & 16.19 & 2064 & 1000000 \\
\hline $51^{*}$ & 7.28 & 5677 & 155752 & 8865 & 75917 & - & - & 0 & 53.73 & 14.02 & 3519 & 1000000 \\
\hline $52^{*}$ & 7.28 & 4297 & 118778 & 6682 & 57861 & - & - & 0 & 58.44 & 15.24 & 2703 & 1000000 \\
\hline $53^{*}$ & 7.28 & 3192 & 88012 & 4974 & 42878 & - & - & 0 & 62.29 & 16.32 & 2002 & 1000000 \\
\hline
\end{tabular}




\section{Notes on APPENDIX E:}

1. The given off-gas compositions for those cases with an asterisk $(*)$ represent the most flammable gas mixture produced during each $7 \mathrm{X} / 3 \mathrm{X}$ off-gas surge run.

2. In all $7 \mathrm{X} / 3 \mathrm{X}$ off-gas surge runs, the $\mathrm{NO}_{\mathrm{x}}$ species were represented by $\mathrm{NO}$ only for the calculational simplicity. 